Ronaldo Benvenuti

\title{
UTILIZAÇÃO DA ARBITRAGEM COMO FORMA DE SOLUÇÃO DE DISPUTAS POR EMPRESAS CONSTRUTORAS
}

Dissertação apresentada à Escola

Politécnica da Universidade de São

Paulo para a obtenção do título de Mestre em Engenharia Civil. 
Ronaldo Benvenuti

\title{
UTILIZAÇÃO DA ARBITRAGEM COMO FORMA DE SOLUÇÃO DE DISPUTAS POR EMPRESAS CONSTRUTORAS
}

\author{
Dissertação apresentada à Escola \\ Politécnica da Universidade de São \\ Paulo para a obtenção do título de \\ Mestre em Engenharia Civil.
}

Área de concentração: Engenharia de Construção Civil e Urbana.

Orientador: Profo. Dr. Francisco

Ferreira Cardoso 
Este exemplar foi revisado e alterado em relação à versão original, sob responsabilidade única do autor e com a anuência de seu orientador.

São Paulo, 03 de junho de 2010.

Assinatura do autor

Assinatura do orientador

\section{FICHA CATALOGRÁFICA}

\section{Benvenuti, Ronaldo}

Utilização da arbitragem como forma de solução de disputas por empresas construtoras / R. Benvenuti. -- ed.rev. -- São Paulo, 2010.

$123 \mathrm{p}$.

Dissertação (Mestrado) - Escola Politécnica da Universidade de São Paulo. Departamento de Engenharia de Construção Civil.

1. Construção civil 2. Arbitragem 3. Conflitos I. Universidade de São Paulo. Escola Politécnica. Departamento de Engenharia de Construção Civil II. t. 


\section{DEDICATÓRIA}

À minha esposa Regina e meu filho Eduardo, presentes que Deus colocou em minha vida 


\section{AGRADECIMENTOS}

Ao Professor Francisco Ferreira Cardoso, pela sua orientação na medida correta, proporcionando o meu amadurecimento e o da própria pesquisa e auxiliando-me nas tomadas de decisões de maneira discreta e eficiente.

Ao Professor Silvio Burratino Melhado e ao Professor Sérgio Alfredo Rosa da Silva, pelas importantes contribuições no meu exame de qualificação.

Aos colegas, em especial a Maurício Brun Bucker, Viviane Araújo, Laura Marcelinni e Ricardo Oviedo pelas discussões e dicas sobre as pesquisas.

Ao amigo e colega de turma, Leonardo Manzione, pelo incentivo inicial para dedicar-me à pesquisa acadêmica.

Aos amigos Eduardo Rottmann, Guilherme Damiani Schvertzaid e Octávio Galvão Neto pelo incentivo e auxílio no decorrer da pesquisa.

À Dra. Fátima Cristina Bonassa Bucker, pelo auxílio na elaboração dos questionários, propiciando transpor o tema do Direito à Engenharia.

Às empresas construtoras OAS, Queiroz Galvão e Andrade Gutierrez, aos órgãos arbitrais institucionais American Chambers of Commerce, Câmara do Comércio Brasil Canadá e SP Arbitral.

Aos escritórios de advocacia Duarte Garcia, Caselli Guimarães e Terra, Abreu Sampaio e Marques Rosado, Toledo César \& Carmona pelas contribuições à pesquisa.

Aos advogados Mário Sérgio Duarte Garcia, Carlos Alberto Carmona, Luis Antonio da Gama e Silva Neto, Luiz Felipe Pinto Graziano, Mauro Cunha Azevedo Neto, Tatiana Roldan Ferri, Rodrigo Pinho Bertoccelli, Caroline da Silva Costa e Jeanlise Velloso Couto.

À bibliotecária Fátima pela revisão das referências, e a todos da secretaria pelo auxílio sempre presente.

À Laís e Camila pelo auxílio na revisão do texto.

À minha esposa Regina, pelo incentivo constante. 


\section{RESUMO}

As atividades da construção civil são intrinsecamente complexas, resultado de muitas variáveis e grande quantidade de informações envolvidas, o que dificulta o gerenciamento dos riscos e a previsão de conflitos, os quais podem vir a se tornar uma disputa. Os contratos, instrumentos de pacto e reguladores das ações dos agentes e celebrados para a realização dos empreendimentos, muitas vezes são mal redigidos e criam um campo fértil para disputas e demandas judiciais, as quais geram prejuízos aos agentes e às partes interessadas envolvidas. A justiça estatal é morosa em função do acúmulo de processos e de alto custo. Como alternativa, foi instituída pela lei federal 9307/96 a arbitragem, uma forma de solução de disputas de forma privada, criada com a intenção de ser rápida, de baixo custo e sigilosa. O objetivo desta pesquisa é o de analisar a freqüência e condições de utilização da arbitragem nos contratos de execução de empreendimentos de construção civil, a identificação das vantagens e desvantagens que uma empresa construtora terá ao utilizá-la de modo a sugerir ações com vistas a incrementar a sua utilização pelas empresas construtoras. Foram utilizados como métodos de pesquisa a revisão bibliográfica e entrevistas de campo com três órgãos institucionais arbitrais, três empresas construtoras e três escritórios de advocacia.

Palavras chave: Construção Civil. Empresa construtora. Arbitragem. Conflitos. 


\begin{abstract}
Construction activities are inherent complex, as a result of a great number of interests and large amount of information involved, what makes risk management and conflict prediction difficult tasks, eventually leading to legal disputes. Construction and engineering contracts often do not cover all risks involved, leading to claims and resulting in losses of time and money for construction firms, engineering companies, property developers, and other stakeholders. The judiciary system is very slow and expensive, and, as an alternative, private arbitration courts were created by federal law 9307/96. Private managed, these courts are expected to be faster, less expensive and confidential. The aim of this research is to analyze the frequency and conditions of the use of arbitration in contracts in civil construction projects, identifying advantages and disadvantages from the point of view of construction companies, aiming to suggest actions as to increase its use. The research method includes bibliographic review and a survey with three institutional private arbitration organizations, three construction firms and three law firms.
\end{abstract}

Key Word: Construction. Construction firm. Contract claims arbitration. Conflicts. 


\section{LISTA DE FIGURAS}

Figura 1: Classificação dos segmentos de obras (Fonte: Mesquita 2006)

Figura 2: Interface contratual entre agentes com possibilidade de utilização da arbitragem (adaptado de Melhado, 2001). 32

Figura 3: Fluxograma de uma arbitragem (Fonte: Schabbel - 2002) ..... 40 


\section{LISTA DE TABELAS}

Tabela 1: Quantidade de casos de arbitragens que envolvem empresas brasileiras na CCI. Fonte: Grion (2007)

Tabela 2: Transcrição das entrevistas com os órgãos institucionais arbitrais

Tabela 3: Transcrição das entrevistas com as empresas construtoras ................ 75

Tabela 4: Transcrição das entrevistas com os escritórios de advocacia 79 


\section{LISTA DE ABREVIATURAS OU SIGLAS}

\begin{tabular}{|c|c|}
\hline \multirow[t]{2}{*}{ ABNT } & Associação Brasileira de \\
\hline & NormasTécnicas \\
\hline ADR & Alternative Dispute Resolution \\
\hline AMCHAM & American Chambers of Commerce \\
\hline ASCE & American Society of Civil Engineers \\
\hline CAMARB & Câmara de Arbitragem Empresarial \\
\hline CCBC & Câmara do Comércio Brasil-Canadá \\
\hline \multirow[t]{2}{*}{ CONIMA } & Conselho Nacional de Mediação e \\
\hline & Arbitragem \\
\hline CPIF & Cost Plus Incentive Fee \\
\hline CPFF & Cost Plus Fixed Fee \\
\hline DBO & Design, Build and Operate Projects \\
\hline DRB & Dispute Review Boards \\
\hline DRA & Dispute Adjudication Board \\
\hline \multirow[t]{2}{*}{ ENAA } & Engineering Advanced Association of \\
\hline & Japan \\
\hline \multirow[t]{2}{*}{ EPC } & Engineering, Procurement and \\
\hline & Construction \\
\hline \multirow[t]{2}{*}{ FIDIC } & Fédération Internationale des \\
\hline & Ingénieurs-Conseils \\
\hline \multirow[t]{2}{*}{ FIESP } & Federação das Indústrias do Estado \\
\hline & de São Paulo \\
\hline FPC & Fixed Price Contract \\
\hline FPIF & Fixed Price Incentive Fee \\
\hline FPP & Firm Fixed Price \\
\hline \multirow[t]{2}{*}{ IBGE } & Instituto Brasileiro de Geografia e \\
\hline & Estatística \\
\hline ICC & International Chamber of Commerce \\
\hline IE & Instituto de Engenharia \\
\hline MCT & Ministério da Ciência e Tecnologia \\
\hline $\mathrm{PCH}$ & Pequena Central Hidrelétrica \\
\hline PMI & Project Management Institute \\
\hline PPP & Parceria Público-Privada \\
\hline
\end{tabular}


SindusCon-SP

STJ
Sindicato da Indústria da Construção

Civil de Grandes Estruturas no Estado de São Paulo

Superior Tribunal de Justiça 


\section{SUMÁRIO}

RESUMO

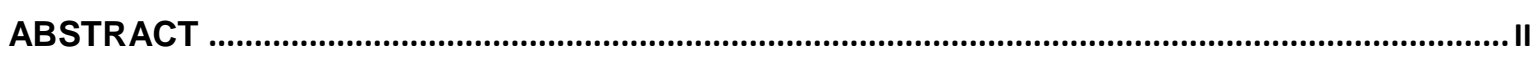

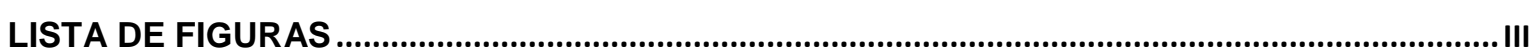

LISTA DE TABELAS

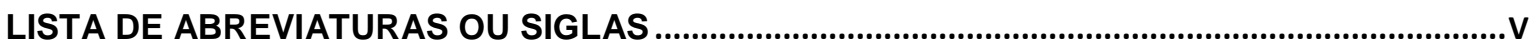

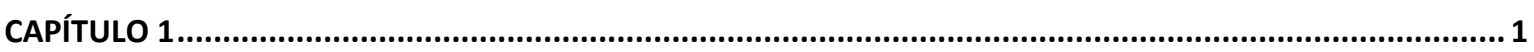

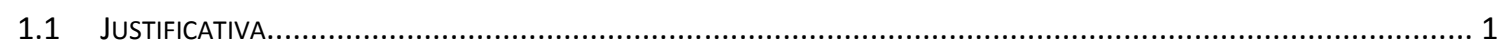

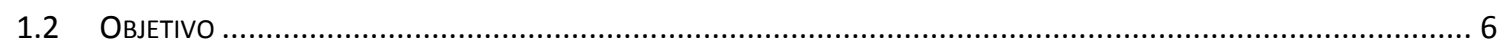

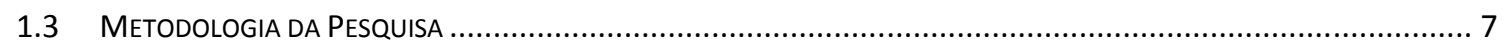

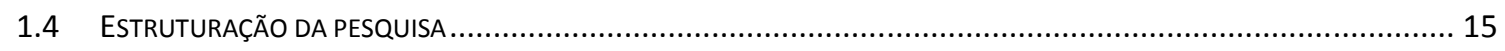

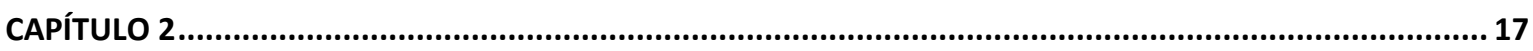

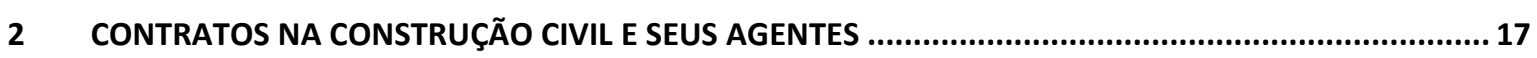

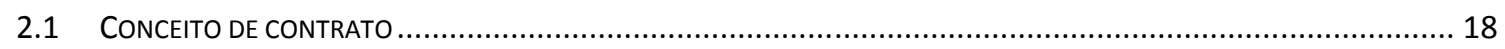

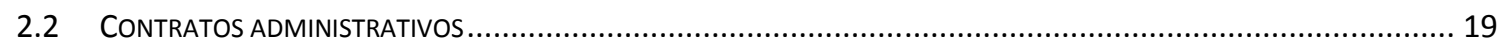

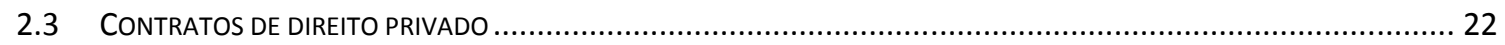

2.4 OS EMPREENDIMENTOS E OS AGENTES ENVOLVIDOS EM UM CONTRATO DE CONSTRUÇÃO CIVIL.............................. 27

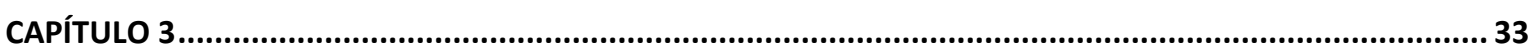

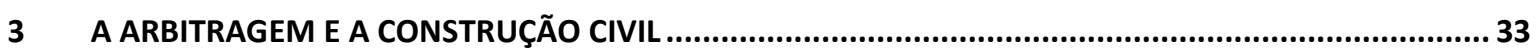

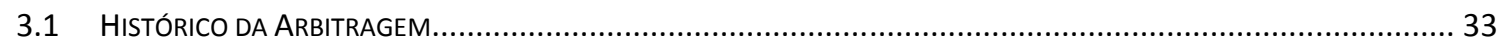

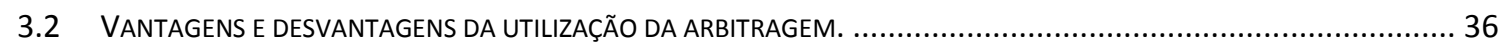

3.3 ANÁLISE DA LEI 9307/1996 - CONDIÇÕES E ESPECTRO DE UTILIZAÇÃO DA ARBITRAGEM............................ 43

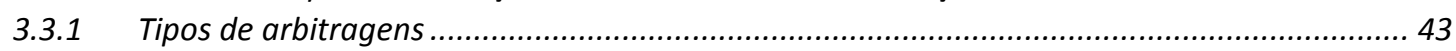

3.3.2 Definição das pessoas que podem se valer da arbitragem e arbitragem em contratos de PPP 44

3.3.3 Arbitragem de direito ou eqüidade................................................................................ 48

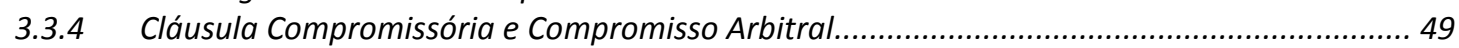

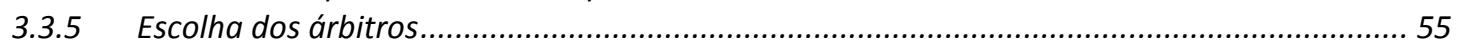

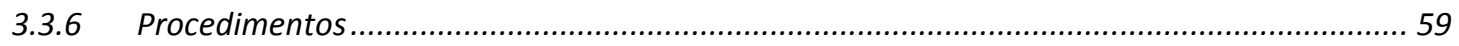

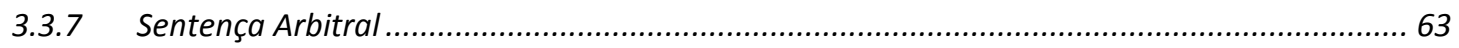

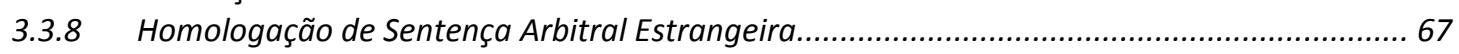

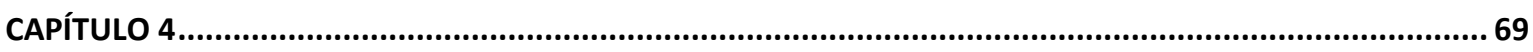

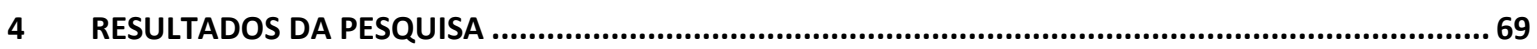

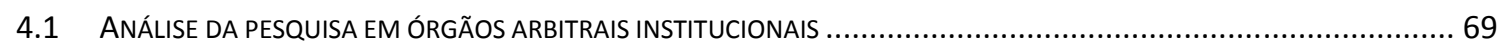

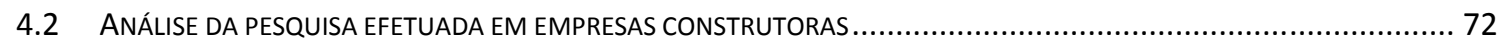

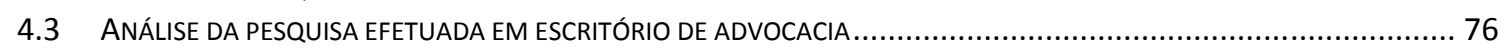

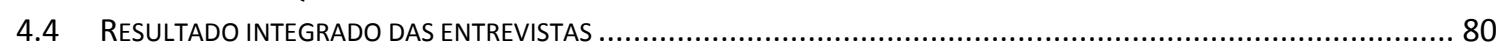

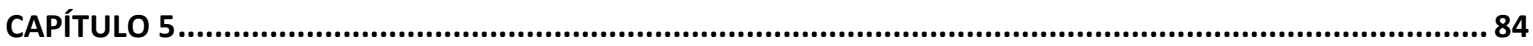

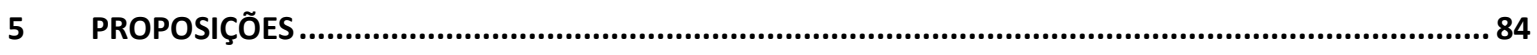

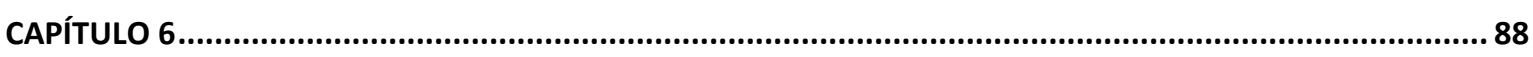

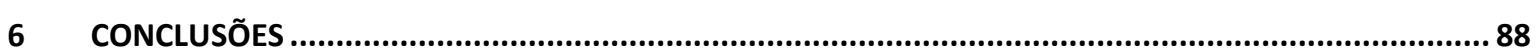

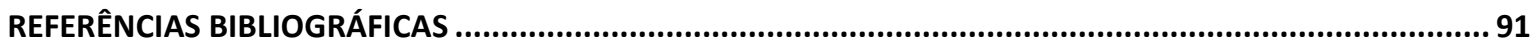




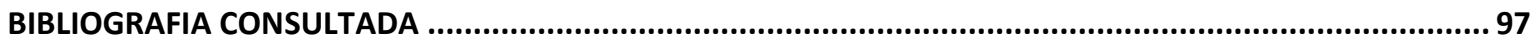

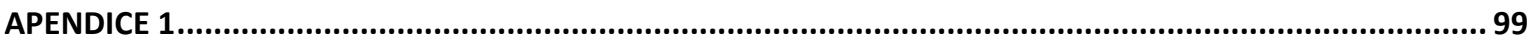

APENDICE 2

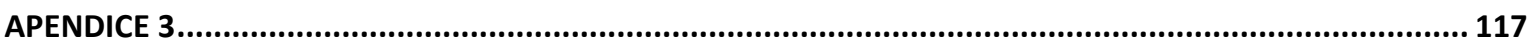




\section{CAPÍTULO 1}

\subsection{Justificativa}

Contratos são pactos entre agentes, definindo um objetivo a ser atingido pelas partes, com direitos e deveres definidos e procurando preservar o equilíbrio econômico-financeiro inicial. $\mathrm{Na}$ construção civil, os contratos ligados aos empreendimentos cobrem um grande espectro de atividades, desde aquisições de terrenos, incorporações, serviços de engenharia consultiva, execução de obras públicas e privadas, aquisição de materiais e outras atividades correlatas. Existem inúmeras variáveis nessas atividades, nem todas previstas nos contratos, por muitas vezes mal redigidos, que não cobrem todo o espectro e escopo do trabalho, resultando em campo fértil para conflitos e disputas ${ }^{1}$. Bueno (2008) e Pedrosa (1994) referenciam algumas causas desses conflitos e disputas:

- Incertezas e adversidades decorrentes de condições pré-existentes não previstas.

- Escopo de projeto errado, confuso ou omisso.

- Atribuições das partes mal definidas dentro do empreendimento.

- Falta de compatibilização das especialidades de projeto.

- Deficiências em planejamento e gestão das obras.

- Problemas pós-início das obras, tais como:

a) Paralisações causadas por problemas técnicos surgidos durante a execução.

\footnotetext{
${ }^{1}$ Neste trabalho o termo conflito será utilizado sempre se referindo aos estados de dissensão, desentendimento, descontentamento e atrito existentes entre pessoas ou organizações, e que caso não sejam solucionados podem vir a se tornar uma disputa ou um litígio. Os termos disputa e litígio serão sempre referenciados como conseqüências de conflitos não resolvidos, ligadas a um objetivo tangível e concreto, podendo depender de intervenções externas às partes para sua solução, tais como mediação, arbitragem, justiça estatal, etc. Embora a lei 9307/96 que instituiu a arbitragem no Brasil utilize o termo litígio, neste trabalho dá-se preferência ao termo disputa.
} 
b) Reduções de verbas.

c) Problemas legais.

d) Alterações significativas no contexto econômico e financeiro no decorrer da obra.

e) Problemas climáticos.

f) Problemas geológicos.

g) Modificações de projeto.

h) Inflação em alta.

i) Interferência do governo na legislação no decorrer da obra (fato do príncipe), tais como alterações tributárias, modificação da legislação ambiental, lançamento de planos econômicos, etc.

Nota-se que as causas dos conflitos e disputas são inúmeras e dispersas em variáveis múltiplas. González (1998), ao tratar das características dos contratos de empreitada e de incorporação imobiliária, destaca que as atividades ligadas às empresas de engenharia e de construção civil são extremamente complexas, por exigirem o gerenciamento de grande quantidade de informações.

Arditi e Patel (1989), discutindo sobre o sistema de gerenciamento de conflitos em empreendimentos de construção civil, alertam que o ambiente do setor é propenso a disputas. Acrescentam, também, que ao haver uma disputa entre construtor e empreendedor, o empreendimento sofre conseqüências e o seu prazo se alonga. Destacam que as disputas podem ser resolvidas por mediações, arbitragens, ou acordos que, porém, consomem tempo e recursos.

Jannadia et al. (2000), ao tratarem dos métodos de elaboração de contratos com resolução alternativa de disputa (ADR, Alternative Dispute Resolution), afirmam que conflitos são uma realidade em cada empreendimento, e que, se as partes não conseguirem chegar a um entendimento no nascedouro do conflito, as conseqüências atingem todos os agentes, ocasionando atrasos, aumentos de custos e riscos de litígios. 
lyer e Satyanarayana (2002) afirmam que as disputas ocorrem também devido a interpretações diversas de termos técnicos utilizados nos contratos de execução de obras. Contratante e contratado têm um único objetivo, compreendido de maneiras diferentes. Como conseqüências, no aflorar de uma disputa, ocorrem atrasos nos serviços, aumento de custos e perda de reputação de construtores e empreendedores.

Percebe-se pelos autores citados a complexidade do ambiente dos empreendimentos de construção civil, com a existência de inúmeras variáveis, dificultando a previsão de diversos fatores que possa gerar conflitos e disputas, tornando-as inerentes à atividade da construção civil e podendo gerar prejuízos aos agentes envolvidos. Até um planejamento detalhado pode ocultar problemas que afloram após o início dos empreendimentos, ocasionando conflitos.

Pedrosa (1994) reforça esta idéia ao afirmar que contratos de longa duração que possam prever todas as condições e situações são quase impossíveis de serem elaborados, cabendo, portanto, sua revisão durante a vigência com o objetivo de estabelecer o equilíbrio econômico-financeiro, especialmente em empreendimentos longos e complexos.

Caso os conflitos aconteçam e se não solucionados chegarem a uma disputa, ao tentarem solucionar suas disputas pela justiça estatal, as partes esbarram em sua morosidade causada pelo excesso de processos e burocracia, pelos custos altos (não só processuais, devendo-se levar em conta o custo total da disputa, tais como lucros cessantes, perdas de insumos devido a paralisações das obras, custos para o reinício da obra, danos à imagem das partes, dentre outros) e pelas dificuldades de julgamento técnico, em função da complexidade dos contratos de empreendimentos de construção civil.

Como resultado, há uma busca mundial de métodos alternativos de gerenciamento de conflitos e solução de disputas por métodos alternativos à justiça estatal, tais como a utilização da Dispute Review Boards (DRB), junta de especialistas que acompanha um contrato, emitindo recomendações, da 
Dispute Advisory Board (DAB), junta de especialistas que emite decisões, e o uso da Medição e da Arbitragem (BUENO, 2008).

No Brasil, com o objetivo de agilizar a solução das disputas, foi promulgada em 1996 a lei no 9.307/96, regulamentada em 2001, instituindo a arbitragem, que é uma forma alternativa de solução de disputas de forma privada, por meio de sentença similar à da justiça estatal, sem interferência do Estado.

Colaiácovo e Colaiácovo (1999) definem arbitragem como o processo consensual em que uma terceira parte, neutra, ouve os argumentos das duas partes sobre a disputa, analisa as evidências e emite uma decisão final, de cumprimento obrigatório e irrevogável.

Maia Neto (2002) descreve a arbitragem como um mecanismo pela qual a resolução da disputa relativa aos direitos patrimoniais disponíveis é feita por árbitros escolhidos pelas partes, de sua confiança, excluindo o poder judiciário, usualmente com conhecimento na matéria, com sigilo, rapidez e eficiência. $O$ uso da arbitragem não é compulsório, mas sim eletivo pelas partes, o que estimularia o entendimento.

Posto isto, a arbitragem, portanto é um mecanismo privado de solução de disputa escolhido pelas partes, que elegem de comum acordo uma terceira parte para analisar a disputa, dispensando a justiça estatal, para dar um veredicto de maneira sigilosa, sem possibilidade de revisão, obrigatório, célere, e constituindo-se título executivo, sendo possível a execução da sentença de imediato pela parte ganhadora à perdedora.

A escolha da solução de disputas pela arbitragem é introduzida no contrato por cláusula compromissória, ou por compromisso arbitral, firmado após a ocorrência do conflito. A arbitragem pode ser utilizada em contratos privados e também em contratos de Parcerias Público-Privadas (PPP), conforme a Lei 11.079 de 30/12/2004, a qual institui as normas gerais deste tipo de parceria entre os órgãos da Administração Pública e empresas particulares, havendo ainda a possibilidade de seu uso em contratos que envolvam empresas mistas e públicas. 
Maia Neto (2002) enumera as vantagens de se utilizar a arbitragem:

- Rapidez na solução das disputas.

- Sigilo.

- Custos menores.

- Redução das formalidades.

Outra vantagem significativa apontada é que o árbitro, ou árbitros, sempre em número ímpar, são escolhidos de comum acordo entre as partes, não são impostos. No caso das empresas de construção civil, o árbitro pode ser um especialista na questão a ser arbitrada, com a conseqüente objetividade, e conferindo qualidade à sentença.

Existem diversas entidades dedicadas à administração de arbitragens, em diversos países, dentre elas cita-se International Court of Arbitration of International Chamber of Commerce, American Arbitration Association, London Court of Arbitration, Câmara de Comércio de Estocolmo, Câmara de Comércio de Tóquio, Tribunal Arbitral da Corte de Comércio de Buenos Aires, Câmara de Comércio, Indústria e Produção da República Argentina.

Para o reconhecimento, homologação e execução de sentenças arbitrais prolatadas em países diferentes, há um tratado internacional, a New York Convention de 1958. Braghetta (2009) informa que 142 países já a reconheceram e a assinaram, inclusive o Brasil em 2002.

Conforme informação proferida por Cássio Telles Ferreira Netto, presidente o Conselho Nacional das Instituições de Medição e Arbitragem (Conima), no $2^{2}$ Congresso Internacional Medição e Arbitragem em 7 de agosto de 2008, existem 110 câmaras de arbitragem no país. Dentre elas podem-se citar como exemplos as câmaras do Instituto de Engenharia (IE), do Instituto Brasileiro de Avaliações e Perícias na Engenharia (IBAPE), da Federação das Indústrias e Comércio do Estado de São Paulo, da Câmara do Comércio Brasil-Canadá e a Câmara Imobiliária de Mediação e Arbitragem do Rio de Janeiro. 
Apesar das perdas potenciais ou efetivas das empresas construtoras, em função de conflitos ligados a contratos no Brasil, a solução de disputas com o uso da arbitragem aparentemente é pouco difundida e aparentemente pouco utilizada.

Para isso contribui a escassez de pesquisas acadêmicas que tratam da arbitragem direcionadas para o setor da construção civil. Quase que exclusivamente as fontes bibliográficas encontram-se na área do Direito, e as raras pesquisas com viés para a área da construção foram elaboradas por engenheiros com formação também em direito, podendo-se citar o Engenheiro e Advogado Francisco Maia Neto, ou por advogados cuja especialidade seja a elaboração de contratos para construção civil. As pesquisas já existentes sobre o tema, em geral artigos e livros, foram feitas a partir da ótica jurídica, e não com uma abordagem sob a ótica das empresas construtoras ou dos empreendimentos de construção civil. As empresas construtoras podem vir a ter uma vantagem competitiva dentro do mercado, pelos aparentes ganhos obtidos na solução de disputas pela arbitragem.

\subsection{Objetivo}

O objetivo desta pesquisa é analisar a freqüência, as razões e condições da utilização da lei no 9.307/1996 da arbitragem nos contratos de execução de empreendimentos de construção civil, buscando identificar as vantagens e desvantagens de sua utilização.

Com este panorama formado, espera-se contribuir sugerindo ações com vistas a incrementar a utilização da arbitragem para a solução de disputas nos contratos de construção civil, trazendo vantagens competitivas às empresas construtoras. 
O foco centra-se nas empresas construtoras, levando-se em conta as interfaces entre os agentes envolvidos nestes contratos, em empreendimentos privados e de Parceria Público-Privada (PPP), tais como edificações e obras de infraestrutura, e considerando-se os riscos potenciais de conflitos.

\subsection{Metodologia da Pesquisa}

A pesquisa lastreou-se em duas etapas, cada qual fazendo uso de um método de investigação: levantamento bibliográfico e pesquisa de campo com pessoas físicas ou jurídicas com experiências no tema pesquisado. Trata-se de pesquisa exploratória, qualitativa, conforme preconizado por Gil (1987). Seguiu-se uma etapa de análise das informações coletadas.

A primeira etapa se constituiu de levantamento e revisão bibliográfica, abrangendo periódicos, livros, legislação, dissertações, teses, jornais, revistas e sites da Internet, com fins de embasar a teoria e aprofundar o conhecimento sobre o tema escolhido. Procurou-se referenciar conceitos, tipos e área de aplicação dos contratos, quais os agentes atuantes e suas interfaces, os motivos dos conflitos e disputas, quais as pesquisa existentes sobre $o$ assunto, qual a legislação existente abrangendo licitações, contratos e, especificamente, sobre a lei da arbitragem, qual seu campo de utilização e suas limitações. A bibliografia nacional existente na área da Engenharia é incipiente, sendo abundante na área do Direito, porém muito centrada nos aspectos jurídicos e sem aplicação direta no gerenciamento de conflitos e solução de disputas em contratos de construção civil. A bibliografia internacional utilizada se refere a causas de conflitos e pesquisas de tipos de contratos, pelo fato da legislação brasileira estar baseada na "civil law", pois utiliza a lei escrita, e a legislação de vários países, inclusive da América do Sul, apoiar-se na "commom law", baseada nos princípios dos casos precedentes (MARCATO, 2007). As palavras chaves pesquisadas foram: 
construção civil, empresas construtoras, arbitragem, conflito, em língua portuguesa; construction, contract claims arbitration, conflicts, em língua inglesa.

A segunda etapa constituiu-se de pesquisa de campo, desenvolvida por meio de entrevistas com questionários estruturados lastreados na pesquisa bibliográfica, direcionadas a órgãos arbitrais institucionais, empresas construtoras e escritórios de advocacia, com experiências no tema pesquisado. Os questionários, seguindo as orientações de Gil (1987), contêm questões possibilitando apenas uma única interpretação, não sugerindo respostas, abrigando a maior gama de informações possíveis. As entrevistas são limitadas pelas cláusulas de confidencialidade e sigilo, tanto nos órgãos arbitrais institucionais como nos contratos entre advogados e empresas construtoras. Valores e nomes são proibidos de serem citados, e as informações fornecidas são de caráter qualitativo, pela limitação existente.

Três órgãos arbitrais institucionais com relevância e atuantes da cidade de São Paulo foram entrevistados com base no questionário estruturado do APÊNDICE 1, onde se transcreve as respostas dadas em cada caso.

O órgão arbitral institucional $\mathrm{O} 1$ é de grande porte e vinculado a uma câmara internacional de comércio de país da América do Norte, e se define como uma organização binacional, sem fins lucrativos, financiada pelo setor privado e independente, que complementa os serviços disponíveis pelo setor comercial do consulado de seu país de origem, com a função de estimular, apoiar e expandir as relações de comércio e investimentos entre empresas privadas no Brasil e no seu país de origem. Seu centro de arbitragem foi fundado em 1979, e dentre seus árbitros estão os redatores do texto da lei 9307/96 e o fundador e diretor da Revista de Arbitragem e Mediação. Sua sede é na cidade de São Paulo. Conforme informações da própria câmara, na data de novembro de 2009, estavam em andamento 70 processos arbitrais, sendo que 44 destes iniciaram-se em 2009. Informa 
também que em 30 anos de existência os processos arbitrais da câmara envolveram casos no valor total de $R \$ 6,3$ bilhoes.

O órgão arbitral institucional O2 é de médio porte, voltado para a mediação e arbitragem empresariais. Foi fundado em 2000, e sua sede é na cidade de São Paulo. É associado à Associação dos Peritos Judiciais do Estado de São Paulo, Federação dos Contabilistas do Estado de São Paulo, Câmara Ítalo-Brasileira de Comércio, Indústria e Agricultura de São Paulo e Instituto Brasileiro de Avaliações e Perícias de Engenharia de São Paulo (IBAPE).

O órgão arbitral institucional $\mathrm{O} 3$ é de grande porte e vinculado a uma câmara internacional de comércio de país da América do Norte, e se define como uma organização não-governamental, sem fins lucrativos, que reúne cerca de 5.400 sócios entre pequenas, médias e grandes empresas. Com sede em São Paulo, está presente também em Belo Horizonte, Brasília, Campinas, Curitiba, Goiânia, Porto Alegre, Recife, Ribeirão Preto, Uberlândia e Salvador. Segundo suas informações, as empresas associadas atuam em todas as áreas da economia e empregam 1,6 milhões de trabalhadores. Do total de companhias sócias, $80 \%$ são brasileiras, $13 \%$ americanas e o restante de outras nacionalidades. Foi fundada em 1919. Seu centro de arbitragem foi criado em 2000, e em 2008 informou que a quantidade de arbitragens subiu $50 \%$ em relação ao ano anterior. Seu presidente é um dos redatores da lei 9307/96 que instituiu a arbitragem no Brasil.

Nas entrevistas procurou-se identificar:

- Qual o volume de casos dos tribunais arbitrais e quantos destes se referem a empresas construtoras.

- Qual a proporção de casos que envolvem contratos privados e PPP.

- Qual a proporção de uso de cláusula compromissória e compromisso arbitral, em empreendimentos privados e PPP.

- Se há algum setor, infraestrutura ou edificações, onde o emprego do mecanismo é mais significativo e quais as razões. 
- Qual o volume de casos em que as partes envolvidas na arbitragem são empresas construtoras e agentes contratados, tais como subempreiteiros, fornecedores e outros.

- Se existem casos de arbitragem entre construtoras/incorporadoras e adquirentes de frações ideais, e qual o volume sobre o total de casos de empresas construtoras.

- Quais as razões pelas quais as empresas construtoras utilizam a arbitragem.

- Quais as razões que explicam sua não utilização.

- Que vantagens ou desvantagens percebem na sua utilização.

- Como as empresas construtoras avaliam os resultados da utilização.

- Quais agentes utilizam a arbitragem com maior freqüência (incorporador, construtor, subcontratado, etc.).

- Se em contratos administrativos já percebeu a utilização da arbitragem.

- Se empresas públicas ou mistas utilizam a arbitragem.

- Se o prazo previsto em lei é cumprido.

- Quais melhorias sugerem para o processo.

- Quais ações sugerem para a maior utilização da arbitragem.

- Se houve crescimento na utilização da arbitragem.

As entrevistas efetuadas em três empresas construtoras utilizaram o questionário estruturado do APÊNDICE 2, onde se transcreve as respostas dadas em cada caso. Estas empresas construtoras foram selecionadas a partir da sua relevância no sub-setor de obras privadas e parcerias públicoprivadas, PPP.

A empresa construtora $\mathrm{C} 1$ foi fundada em 1948 e atualmente faz parte de um grupo empresarial que atua nas áreas de engenharia, construção, telecomunicações, energia e concessões públicas, tanto no Brasil como em outros países. O faturamento geral do grupo em 2008 foi de $R \$ 11,75$ bilhões, e na área de engenharia e construção foi de $R \$ 4,34$ bilhões. Neste setor atua em projetos ligados à área petrolífera e obras de infraestrutura, tais como refinarias, gasodutos, metrô, termelétricas, rodovias e obras de 
saneamento. Sua sede é na cidade de São Paulo, e é associada à International Finance Corporation, que por sua vez faz parte do Banco Mundial. No ranking da Revista Exame das melhores empresas da área da construção em 2008, a construtora C1 é a $11^{a} \stackrel{a}{\text { colocada. }}$

A empresa construtora C2 é uma das cinco maiores construtoras do Brasil, e atua também no exterior. Foi fundada em 1976. Atua no setor de infraestrutura (estradas, ferrovias, obras de saneamento, pontes, túneis, hidrelétricas), edificações (indústrias, hotéis, shopping centers, prédios comercias e residenciais) e concessões de serviços públicos. Sua sede é na cidade de São Paulo. Seu faturamento bruto em 2008 foi de US\$ 843 milhões. No ranking da Revista Exame das melhores empresas da área da construção em 2008, a construtora C2 é a $12^{\text {a }}$ colocada.

A empresa construtora $\mathrm{C} 3$, com sede no Rio de Janeiro, foi fundada em 1953, e faz parte de um grupo empresarial que atua nas áreas de engenharia, construção, perfuração e produção de óleo e gás, cultivo e beneficiamento de alimentos, concessão de serviços públicos no Brasil (rodovias, empresas de saneamento e de energia), siderurgia e serviços de engenharia ambiental, no Brasil, África e América Latina. $\mathrm{Na}$ área de construção civil atua em infraestrutura, com empreendimentos em hidrelétricas, saneamento, recursos hídricos, plataformas para exploração de petróleo e gás, rodovias, ferrovias, aeroportos, metrôs e portos. No subsetor de edificações, seus empreendimentos estão concentrados na área residencial e comercial de alto padrão. O faturamento geral do grupo em 2008 foi de $R \$ 5,52$ bilhões, e na área de construção foi de $R \$ 3,79$ bilhões. No ranking da Revista Exame das melhores empresas da área da construção em 2008, a construtora C3 é a $3^{a}$ colocada.

Nas entrevistas procurou-se identificar:

- Quais as razões pelas quais incluem em seus contratos a cláusula compromissória.

- Quais as razões que explicam a não inclusão da cláusula compromissória em seus contratos. 
- Qual a proporção da inclusão da cláusula compromissória em cada tipo de obra, em contratos privados e de PPP.

- Quais as razões pelas quais, quando não utilizam a cláusula compromissória, fazem uso do compromisso arbitral em situações de disputa, em que proporção isso ocorre e para que tipos de obras.

- Se utilizam a arbitragem também com os agentes contratados, com quais e em que proporção.

- Quais segmentos de obras mais a utilizam.

- No caso de ser incorporador, se insere a cláusula compromissória nos contratos de venda de frações ideais.

- Se já assinou contrato com a previsão do uso da arbitragem em contratos administrativos, ou em contratos com empresas públicas ou mistas.

- Que vantagens percebem na utilização da arbitragem.

- Quais são as desvantagens na utilização da arbitragem.

- Como avaliam os resultados obtidos.

- Quais melhorias sugerem para o processo.

- Quais os motivos dos conflitos.

- Qual o tipo de contrato de construção utilizado.

- Se a arbitragem utilizada é institucional ou ad hoc, quantos árbitros são utilizados e se o prazo é seguido.

- Se já utilizou outros mecanismos de gerenciamento de conflitos ou solução de disputas.

Em três escritórios de advocacia as entrevistas forma conduzidas utilizandose o questionário estruturado do APÊNDICE 3 , onde se transcreve as respostas dadas em cada caso. Foram previamente selecionados os escritórios de advocacia de comprovada relevância do setor, e que assessoram ou assessoraram empresas construtoras em tribunais arbitrais.

O escritório de advocacia E1 é um dos maiores da cidade de São Paulo, e tem filiais em Brasília e Pequim. É associado a escritórios em Lisboa, Miami e Buenos Aires. Foi fundado há 50 anos, e conta com 60 advogados em seu quadro de profissionais. Um de seus sócios é coordenador do Conselho 
Jurídico do Sindicato da Indústria da Construção Civil do Estado de São Paulo (SindusCon-SP). O sócio entrevistado é árbitro da Câmara do Comércio Brasil-Canadá ( $\mathrm{CCBC}$ ), vice-presidente da câmara de mediação e conciliação da Federação das Indústrias do Estado de São Paulo (FIESP), membro honorário vitalício do conselho federal da Ordem dos Advogados do Brasil $(\mathrm{OAB})$ e do conselho secional da OAB/SP, e foi secretário da justiça do Estado de São Paulo de 1987 a 1990.

O escritório de advocacia E2 foi fundado em 1982, e tem sua sede em São Paulo. Na área de arbitragem é associado à American Chambers of Commerce (AMCHAM). Tem entre seus clientes uma das maiores empresas construtoras e incorporadoras do país, com potencial declarado de vendas de $\mathrm{R} \$ 16$ bilhões. O advogado entrevistado é especialista na área imobiliária, e assessora as empresas construtoras deste escritório.

O escritório de advocacia E3 foi fundado em 1995, e tem sua sede em São Paulo. Dentre suas especialidades está o direito imobiliário e a arbitragem. O sócio entrevistado é um dos redatores da lei 9307/96. É árbitro nas principais câmaras brasileiras de arbitragem: Câmara de Mediação e Arbitragem de São Paulo, Centro de Arbitragem da AMCHAM, Centro de Mediação e Arbitragem da CCBC, Câmara de Arbitragem Empresarial (CAMARB), da câmara de arbitragem da Fundação Getúlio Vargas, e na International Chamber of Commerce (ICC).

Nas entrevistas procurou-se identificar:

- Dos casos levados a tribunais arbitrais qual o percentual destes se refere a empresas construtoras.

- Quantas arbitragens se referem a obras privadas e quantas a PPP.

- Que vantagens percebem na utilização da arbitragem.

- Quais são as desvantagens da utilização da arbitragem.

- Qual a freqüência de inclusão de cláusula compromissória nos contratos que realiza para seus clientes construtoras.

- Se há algum agente que utiliza com maior freqüência a arbitragem. 
- Se há algum segmento do setor da construção civil onde o emprego da arbitragem é mais significativo (edificações ou infraestrutura).

- Se em incorporações utilizam a arbitragem para solucionar disputas com adquirentes das frações ideais.

- Qual o tipo de contrato utilizado.

- Se utilizou a arbitragem em contratos administrativos.

- Como as empresas construtoras avaliam os resultados obtidos.

- Quais melhorias sugerem para o processo.

- Quais os motivos dos conflitos.

- Se utiliza a arbitragem institucional ou ad hoc, com quantos árbitros, e se o prazo é cumprido.

As entrevistas com os órgãos institucionais arbitrais, empresas construtoras e escritórios de advocacia ocorreram nos meses de novembro e dezembro de 2009.

A seguir procedeu-se a uma análise crítica das informações coletadas pela pesquisa e pelas entrevistas, identificando-se as vantagens e desvantagens da utilização da arbitragem.

Finalmente, sugeriram-se ações com vistas a difundir e incrementar a utilização da arbitragem em contratos de construção civil.

Os questionários, antes de serem aplicados, e as referências bibliográficas utilizadas foram analisados por advogada com sólida formação acadêmica e relevância no meio jurídico, especialista em arbitragem, com fins de garantir a qualidade da pesquisa. 


\subsection{Estruturação da pesquisa}

A pesquisa está estruturada em 6 capítulos, seguido de um com as referências bibliográficas e de três apêndices com as transcrições das entrevistas.

No primeiro capítulo apresenta-se a justificativa para a escolha do tema da pesquisa, os objetivos a serem alcançados e a metodologia empregada.

No segundo capítulo há uma análise dos tipos de contrato utilizados pelas empresas de construção civil, um panorama do mercado de atuação das empresas construtoras e seus sub-setores, quais os diversos agentes que atuam em empreendimentos de construção civil privados e em PPP, quais os riscos potenciais de conflitos e disputas.

O terceiro capítulo trata da arbitragem conceitualmente, apresentando-se um histórico de sua utilização no tempo, os motivos da promulgação da lei №. 9307/96, uma análise desta lei, as vantagens e desvantagens de sua utilização e suas opções e condições de aplicação em empreendimentos privados e de PPP.

No quarto capítulo é apresentado o resultado da pesquisa sobre a utilização da arbitragem pelas empresas construtoras, sob o ponto de vista dos três agentes investigados, ou seja, os órgãos institucionais arbitrais, as empresas construtoras e os escritórios de advocacia, e é feita a análise dos resultados obtidos, confrontando-as com as informações adquiridas na revisão bibliográfica, em especial as do terceiro capítulo.

No quinto capítulo são apresentadas as proposições desta pesquisa, com sugestões para o incremento da utilização da arbitragem nos contrato de construção civil.

No sexto capítulo são apresentadas as considerações finais, levando-se em conta as limitações existentes desta pesquisa, as contribuições ao tema, o 
êxito obtido frente aos objetivos desta pesquisa, e as possíveis alternativas de continuidade do tema.

Os apêndices 1 a 3 trazem as transcrições das entrevistas realizadas com os órgãos institucionais arbitrais, empresas construtoras e escritórios de advocacia. 


\section{CAPÍTULO 2}

\section{Contratos na construção civil e seus agentes}

O contrato é o instrumento regulador de um empreendimento, onde estão contidas as regras a serem seguidas pelas partes, com o objetivo do empreendimento vir a ser realizado dentro dos parâmetros pré-acordados, tais como preço, prazo, qualidade, condições de pagamento e outras condições. Com isso procura-se evitar o surgimento de conflitos e disputas. O objeto e condições dos contratos de empreendimentos de construção civil são diferenciados dos contratos comuns em função das particularidades do setor, tais como a não repetitividade do produto, a diversidade de soluções técnicas, a grande quantidade de informações contidas e os inúmeros agentes atuantes.

Espera-se que um bom contrato mitigue os riscos de conflitos e, sobretudo, de disputas, e por isso um bom contrato é importante. No caso da arbitragem, no contrato estão as condições para a sua utilização. Conforme Strenger (1996), na raiz de qualquer procedimento arbitral se encontra o contrato. Complementa com a informação:

"o contrato, sem dúvida, é o pilar de sustentação dos ajustes concernentes à sua finalidade e propósito, abordando, nem sempre com propriedade e clareza, o contexto disciplinador de sua execução".

É, portanto, necessário conhecer a natureza e tipos de contratos com a finalidade de mitigar os riscos que podem levar a conflitos e disputas.

Neste capítulo são expostos o conceito de contrato, sua classificação segundo o agrupamento jurídico mais comum, os modelos de contratos padrão oferecidos por entidades para a utilização especificamente em empreendimentos de construção civil, quais os agentes que atuam nos contratos, e a classificação dos setores produtores dos empreendimentos, 
com fins de compreensão do contexto geral em que os contratos de construção civil estão inseridos.

\subsection{Conceito de contrato}

Sob uma ótica jurídica, segundo Costa e Junqueira (2008), um contrato pode ser assim definido:

"Contrato é o ato jurídico em que duas ou mais pessoas se obrigam a dar, fazer ou não fazer alguma coisa, verificando, assim, a constituição, modificação ou extinção do vínculo patrimonial".

Pedrosa (1994) cita:

"O contrato é um pacto entre duas ou mais pessoas - físicas ou jurídicas - no qual se estabelecem regras e normas, que, sem ofender a lei maior, passarão a ser respeitadas como vontade única daqueles que a firmaram."

Sob uma ótica da gestão de projetos ou empreendimentos de engenharia, o Project Management Institute (PMI, 2004) define:

"Um contrato é um acordo que gera obrigações para as partes, e que obriga o fornecedor a oferecer o produto, serviço ou resultado especificado e o comprador a pagar por ele".

Condensando os conceitos descritos, pode-se dizer que um contrato celebra um acordo entre duas ou mais pessoas, físicas ou jurídicas, para atingir um objetivo sob determinadas condições aceitas consensualmente pelas partes, que deve ser cumprido fielmente com o devido estabelecimento de direitos e deveres, limitados ao respeito às leis vigentes, geralmente ocasionando sanções à parte que o descumprir. $\mathrm{O}$ contrato deve conter o equilíbrio entre as partes, com direitos e deveres balanceados, evitando-se disputas futuras por prejuízos causados a uma das partes por desequilíbrio financeiro.

Os contratos podem ser feitos de duas formas: 
Por instrumento público, lavrados em registro público, por oficial, ficando desta maneira arquivado e registrado no cartório onde foi redigido e assinado, e seguindo determinadas regras.

Por instrumento particular, podendo ser lavrado pelas partes ou advogados ou outros profissionais indicados, não tendo o formalismo de leitura exigido pelo registro público.

Um contrato adequado deve conter, segundo Bueno (2008):

A qualificação das partes envolvidas, dos contratantes e das contratadas.

O objeto do trabalho, ou seja, a descrição do que está sendo contratado, e obrigações gerais das partes.

As condições de execução, descrevendo o prazo e cronogramas a serem seguidos, documentações necessárias, normas aplicáveis, projetos e outras informações.

O regime de contratação, preço, reajustes e forma de pagamento.

As penalidades.

As formas de rescisão.

As garantias.

As soluções de controvérsias, por via da justiça estatal, ou vias alternativas como medição, arbitragem, etc.

\subsection{Contratos administrativos}

Em caso de contratação de obra ou serviço público, quando o contratante é a administração pública e o contratado uma empresa privada, o contrato é 
chamado de administrativo, e tem características peculiares, pois os interesses públicos se sobrepõem aos interesses privados, representados pela outra parte do contrato. Neste caso podem ser aplicadas as cláusulas exorbitantes, que concedem privilégios à administração pública, podendo alterar unilateralmente o contrato, justificadas pelo objetivo do atendimento ao interesse público. Pedrosa (1994), referindo-se aos contratos de empreitada, reitera, porém, que a administração pública pode alterar 0 projeto e as condições de execução do contrato, porém não pode trazer desequilíbrio financeiro, prejudicando o contratado.

As obras e os serviços públicos são regidos pela lei 8666/93, que exige licitações para sua contratação e estabelece condições para as alterações contratuais, que podem ser:

Unilateralmente pela administração:

- Quando houver modificação do projeto ou das especificações, para melhor adequação técnica aos seus objetivos.

- Quando for necessária a modificação do valor contratual em decorrência de acréscimo ou diminuição quantitativa de seu objeto, nos limites permitidos pela Lei.

Por acordo entre as partes:

- Quando é conveniente a substituição da garantia de execução (caução em dinheiro ou títulos públicos, seguro-garantia, fiança bancária).

- Quando for necessária a modificação do regime de execução da obra ou serviço, bem como do modo de fornecimento, em face de verificação técnica da inaplicabilidade dos termos contratuais originários. 
- Quando for necessária a modificação da forma de pagamento, por imposição de circunstâncias supervenientes, ou seja, que sobrevém sem prévio aviso.

- Para restabelecer a relação que as partes pactuaram inicialmente entre os encargos do contratado e a retribuição da administração para a justa remuneração da obra, serviço ou fornecimento, objetivando a manutenção do equilíbrio econômico-financeiro inicial do contrato, na hipótese de sobrevirem fatos imprevisíveis, ou previsíveis, porém de conseqüências incalculáveis, retardadores ou impeditivos da execução do ajustado, ou, ainda, em caso de força maior, caso fortuito ou fato do príncipe, configurando área econômica extraordinária e extracontratual.

As obras e serviços públicos, segundo a lei 8666/93, podem ser executadas de forma direta (pelos órgãos e entidades da Administração, pelos próprios meios) ou de forma indireta (contratando terceiros).

No caso de execução indireta, a contratação deverá ser nas seguintes formas, segundo a lei 8666/93:

Empreitada por preço global, quando se contrata a obra ou serviço por preço certo e total.

Empreitada por preço unitário, quando se contrata a obra ou serviço por unidades de execução.

Tarefa, quando se ajusta mão-de-obra para pequenos trabalhos por preço certo, com ou sem fornecimento de material.

Empreitada integral, quando se contrata um empreendimento em sua integralidade, compreendendo todas as etapas das obras, serviços e instalações necessárias, sob inteira responsabilidade da contratada até a sua entrega ao contratante em condições de entrada em operação, atendidos os requisitos técnicos e legais para sua utilização 
em condições de segurança estrutural e operacional e com as características adequadas às finalidades para que foi contratada.

No caso das PPP os contratos também são considerados administrativos, porém nelas as cláusulas exorbitantes são atenuadas pelo equilíbrio entre os participantes da parceria. Oliveira (2005) reitera que nos contratos de PPP as partes públicas e privadas sofrem uma dependência recíproca, com direitos e deveres balanceados, o que na prática se traduz no amortecimento e diluição do efeito das cláusulas exorbitantes.

\subsection{Contratos de direito privado}

Define-se como contrato de direito privado aquele celebrado entre empresas privadas. Não há uma rigidez das condições como no contrato administrativo, e neste caso as partes podem livremente repactuar as condições iniciais, desde que consensualmente e sem ferir as leis.

Não há um agrupamento formal para os contratos privados assim como existe para os contratos administrativos, definidos pela lei 8666/93, em empreitada por preço global, empreitada por preço unitário, tarefa e empreitada integral. Porém, alguns autores os separam por categorias.

Gonzalez (1998) separa os contratos privados em dois tipos: os contratos de construção e os contratos de incorporação imobiliária. Conceitua, também, que os contratos de construção podem ser firmados por empreitada ou por administração.

O Project Management Institute (PMI, 2004) considera que os contratos podem ser inseridos em três categorias gerais:

Contrato de preço fixo ou preço global, que consiste de um preço total fixo para um produto bem definido. 
Contrato de custos reembolsáveis, cuja forma de pagamento consiste no pagamento ao contratado por seus custos reais diretos e indiretos.

Contrato por tempo e material, que é um contrato híbrido por conter aspectos tanto do contrato por preço fixo (preços unitários préfixados) como do contrato de custos reembolsáveis (já que o valor total do serviço ou acordo não é pré-fixado no momento da assinatura do contrato).

O mesmo instituto (PMI, 2004) define por forma de remuneração os seguintes tipos de contratos:

Contrato de custo mais taxa de incentivo ou CPIF, Cost Plus Incentive Fee, onde o contratante reembolsa o contratado pelos custos permitidos, advindo o lucro caso o contratado atinja os critérios de desempenho definidos no contrato.

Contrato de custo mais taxa fixa ou CPFF, Cost Plus Fixed Fee, ou remuneração por administração, onde é pago ao contratado uma taxa sobre os custos da obra definidos pelo contrato.

O contrato de preço fixo, ou FPC, Fixed Price Contract, onde o preço do produto é fixo.

Contrato de preço fixo com taxa de incentivo ou FPIF, Fixed Price Incentive Fee, onde o contratante paga ao contratado um valor fixado em contrato, com adicionais caso atenda a critérios de desempenho pré-definidos.

Contrato de preço fixo garantido, ou FPP, Firm Fixed Price, onde o preço do produto é fixo, independentemente dos custos do contratado.

Contrato por tempo e material, que é um contrato híbrido por conter aspectos tanto do contrato por preço fixo (preços unitários préfixados) como do contrato de custos reembolsáveis (já que o valor 
total do serviço ou acordo não é pré-fixado no momento da assinatura do contrato).

Ricardino (2007) agrupa os contratos de construção em uma categoria quanto à forma de remuneração e à abrangência do objeto do contrato:

Empreitada Integral, conforme definido pela lei 8666/93 e já citado anteriormente, quando se contrata um empreendimento compreendendo todas as etapas das obras, serviços e instalações necessárias, sob inteira responsabilidade da contratada até a sua entrega ao contratante em condições de entrada em operação, adequadas às finalidades para que foi contratada. Caso a contratada também forneça o projeto básico, é também chamado de contrato EPC Turnkey, onde EPC são as iniciais de Engineering, Procurement and Construction, ou seja, Projetos, Suprimentos e Construção. Turnkey pode ser definido pela expressão "chave na mão", uma analogia à compra de um automóvel, onde é só ligá-lo para iniciar sua utilização.

Preço Global, onde a contratação é por preço fixo, com remuneração por etapa alcançada. É também conhecido por Lump Sum. Ricardino (2007) salienta que nesta modalidade cabe à contratada o levantamento dos quantitativos dos serviços e a formação dos preços, elevando seu risco no negócio.

Metas ou alvos, ou Aliança, onde as partes se compõem para dividir os riscos, compondo juntos o orçamento para composição do preço dos serviços, os alvos a serem atingidos e a remuneração da contratada caso os alvos sejam alcançados.

Preços unitários, quando se contrata a obra ou serviço por unidades de execução.

Administração, onde a contratada é remunerada pela incidência de uma taxa sobre os custos da obra definidos pelo contrato. 
Bueno (2008) define ainda mais um tipo de contrato, englobando duas modalidades abordadas por Ricardino (2007), a empreitada integral e 0 preço global, que vem a ser o contrato EPC Turnkey Lump Sum, que traduzido livremente seria um contrato que inclui projetos, suprimentos, construção, com "chave na mão" e a preço fixo.

Baseando-se nas definições anteriores, de maneira simplificada pode-se dizer que os contratos podem ser assim agrupados:

Por empreitada, podendo-se considerar o fornecimento dos projetos, integral ou não, a preço global ou preços unitários, considerando-se somente a mão-de-obra, ou considerando mão-de-obra e os materiais, a ser paga por medições ou alvos alcançados, com bonificação ou não.

Por administração, onde a remuneração da empresa construtora se dá pela incidência de uma taxa sobre os custos da obra, a serem definidas pelas partes.

A elaboração de um contrato não é tarefa simples, com uma complexidade crescente proporcional ao vulto da obra e serviços, e às especialidades envolvidas. Cabe ao suporte jurídico assessorar as empresas de engenharia na elaboração dos contratos.

Uma alternativa para a elaboração de contratos vem da Fédération Internationale des Ingénieurs-Conseils (FIDIC), organização internacional que se define como representante global das empresas de engenharia consultiva, promovendo e desenvolvendo relações comerciais entre os agentes, e suprindo-as com trabalhos por ela desenvolvidos, tais como modelos de contratos. Nestes, os agentes envolvidos são as empresas de engenharia, governo, órgãos de financiamento, indústria, comércio, fornecedores e outros profissionais da construção.

Os modelos de contratos da FIDIC são os seguintes, conforme descrito em seu site de internet: 
> Green Book, Shirt Form of Contract - para serviços de engenharia de pequeno valor, de escopo simplificado, repetitivos ou de pequena complexidade, com projetos fornecidos pelo contratante.

Red Book, Conditions of Contract for Construction - para serviços de engenharia e construção, com projetos e escopo fornecidos pelo contratante à empresa construtora.

The MDB Harmonised Conditions of Contract for Construction - para serviços de engenharia e construção, com projetos e escopo fornecidos pelo contratante, nas condições de financiamento de projetos pelo Multilateral Development Banks, ou seja, para a obtenção de financiamento das obras por organismos internacionais, em geral de infraestrutura.

Yellow Book, Conditions of Contract for Plant and Design-Build - sob o arranjo usual deste tipo de contrato o contratado fornece, atendendo aos pré-requisitos do contratante, os projetos, equipamentos elétricos e mecânicos, e serviços civis, mecânicos e elétricos.

Silver Book, Contract for EPC/Turnkey Projects - como já definido anteriormente, quando se contrata um empreendimento compreendendo todas as etapas das obras, serviços e instalações necessárias, inclusive projeto, sob inteira responsabilidade da contratada até a sua entrega ao contratante em condições de entrada em operação, adequadas às finalidades que foi contratada.

DBO, Design, Build and Operate Projects - são aqueles nos quais o proprietário contrata o projeto, a construção e o compromisso de operação em longo prazo, cabendo ao contratado a responsabilidade total sobre todo o empreendimento. O objetivo é o de agregar inovação, qualidade e desempenho ao empreendimento, ao vincular a execução à operação a longo prazo, estimado pela FIDIC em 20 anos. 
Ricardino (2007) cita outras fontes que elaboram minutas de contratos, tais como a American Society of Civil Engineers (ASCE), a Engineering Advanced Association of Japan (ENAA) e o Institute of Civil Engineers, em geral voltados para a obtenção de financiamentos para obras de infraestrutura.

Em todos estes modelos de contratos é possível a aplicação da arbitragem como forma de solução de disputas, pois conforme está detalhado no Capítulo 3 desta pesquisa, as condições para sua utilização estão presentes, tais como a disponibilidade de direitos patrimoniais e a capacidade de contratar dos agentes.

\subsection{Os empreendimentos e os agentes envolvidos em um contrato de construção civil}

No setor da construção civil existem diversos sub-setores produtores de empreendimentos, com a atuação de diversos agentes, que são as partes dos contratos.

Mesquita (2006) descreve que estes empreendimentos são complexos e com várias particularidades, tais como:

A ausência de instalações definitivas para a produção, com variabilidade de locações internas no canteiro.

Produção sujeita às intempéries.

A presença de diferentes profissionais e utilização de vários equipamentos e ferramentas,

A complexidade e variabilidade tecnológica dos processos construtivos, com grande multiplicidade de materiais, componentes e tecnologias. 
O envolvimento de grande número de fornecedores (insumos, recursos humanos, equipes, serviços de projeto e consultoria) e de gestores do empreendimento.

O fato dos empreendimentos serem únicos, temporários e não repetitivos, sujeitos a influências externas e internas.

A atuação de diversos agentes, diferentes do trinômio "clienteintermediário-fornecedor" da indústria seriada.

Concluindo, Mesquita (2006) afirma que cada novo empreendimento utiliza uma gestão própria, diferente de outro empreendimento, devido às suas complexidades e particularidades. Melhado (2001) complementa este conceito com o da empresa-empreendimento, onde este é tratado como uma empresa efêmera, duradoura enquanto existir o empreendimento. Define que para estabelecê-lo é necessário formar uma equipe multidisciplinar envolvendo o empreendedor, projetistas, construtores e outros agentes. Henry (1994) apud Melhado (2001) definem a empresaempreendimento:

\footnotetext{
"grupamento temporário de competências, que tem por objetivo desenvolver um projeto, da forma mais interessante para cada agente, e o gerenciar até a fase de entrega da obra, atendendo às exigências técnicas, arquitetônicas, econômicas e normativas".
}

A construção civil trabalha, portanto, por empreendimentos e reunindo novos agentes a cada vez que um deste se inicia, com todas as suas singularidades próprias descritas.

Em relação aos setores produtivos de empreendimentos, onde atuam os agentes, estes podem ser classificados de maneiras diversas. Uma destas classificações é a do Ministério da Ciência e Tecnologia (MCT, 2000):

Infraestrutura:

- Obras de transportes (rodovias, ferrovias, aeroportos, portos). 

- Obras de distribuição de água e saneamento.
- Obras de distribuição de energia.
○ Obras de telecomunicações.

\section{Edificações:}

- Edificações relacionadas às obras de infraestrutura (rodoviários, terminais de aeroportos, estações de tratamento, etc.).

- Edificações hospitalares, escolares, de segurança, administrativas, etc.

- Edificações comerciais - sedes administrativas, escritórios para venda e locação (incorporação imobiliária), shopping centers, lojas individuais de todos os ramos do comércio (hipermercados, restaurantes, etc.), centros de distribuição.

- Edificações industriais - unidades fabris.

- Edificações residenciais - no segmento de edificações residenciais o mercado é segmentado, em geral, pelas variáveis sócioeconômicas e pela tipologia construtiva (unidades habitacionais unifamiliares e unidades habitacionais multifamiliares).

Mesquita (2006), reunindo informações da Fundação João Pinheiro 1984), IBGE (2004), ABNT (1984) e Martucci (1990), classifica o setor em segmentos, levando-se em conta o tipo de uso, conforme figura 1 :

\begin{tabular}{|c|c|c|c|}
\hline $\begin{array}{c}\text { FUNDAÇẢO JOÃO } \\
\text { PINHEIRO (1984) }\end{array}$ & IBGE (2004) & ABNT-NBR (1984) & MARTUCCI (1990) \\
\hline $\begin{array}{l}\text { Edificaçŏes, } \\
\text { Construçăo Pesada; } \\
\text { Montagem Industrial. }\end{array}$ & $\begin{array}{l}\text { Edificaçōes; } \\
\text { Obras viárias; } \\
\text { Obras de arte especiais; } \\
\text { Obras de mortagern, } \\
\text { Obras de outros tipos. }\end{array}$ & $\begin{array}{l}\text { Obras de E Efficações; } \\
\text { Obras Viárias; } \\
\text { Obras Hidráulicas; } \\
\text { Obras de Sistemas } \\
\text { Industriais; } \\
\text {. Obras de Urbanizaçăo, } \\
\text {. Obras Diversas. }\end{array}$ & $\begin{array}{l}\text { Construçăo Pesada; } \\
\text {.E dificaçōes. }\end{array}$ \\
\hline
\end{tabular}

Figura 1 - Classificação dos segmentos de obras (Fonte: Mesquita, 2006) 
Separando-se as obras em públicas e privadas, pode-se a princípio descrever os agentes atuante em um contrato da seguinte forma:

Obras públicas, regidas pela lei 8666/93:

- O proprietário da obra, no caso o governo, representado pelos órgãos públicos, entidades administrativas ou empresas públicas.

- O construtor, aquele que é contratado para a execução do serviço ou obra.

Em obras privadas existem diversas modalidades de negócios e contratos, desde execução de obras, prestação de serviços de engenharia, incorporações, construções "built to suit", alianças, jointventures, etc. Frente a este cenário, diversos são os agentes atuantes e seu entrelaçamento contratual. Pode-se, independente do tipo de contrato e da sua interdependência, indicar os agentes atuantes mais comuns:

- O empreendedor, aquele que promove a obra, que a gera e impulsiona. Neste caso, podem existir diversos arranjos diferentes:

- Pode ser apenas o dono da construção, como, por exemplo, um empreendedor que constrói sobre o terreno de outro, com direito de uso do imóvel por determinado período de tempo.

- Nas construções de edifícios residenciais e comerciais, o empreendedor é o incorporador responsável conforme a lei 4591/64 por "promover e realizar a construção, podendo ser pessoa física ou jurídica, comerciante ou não, que embora não efetuando a construção, compromisse ou efetive a venda de frações ideais de terreno objetivando a vinculação de tais frações a unidades autônomas, em edificações a serem construídas ou em construção sob regime condominial, ou que meramente aceite propostas para efetivação de tais 
transações, coordenando e levando a têrmo a incorporação e responsabilizando-se, conforme o caso, pela entrega, a certo prazo, preço e determinadas condições, das obras concluídas". Segundo a lei, o incorporador somente pode ser: a) o proprietário do terreno, o promitente comprador, o cessionário deste ou promitente cessionário; b) o construtor ou corretor, neste caso investidos por instrumento público de poderes especiais para concluir todos os negócios tendentes à alienação das frações ideais de terreno, e que se obrigará pessoalmente pelos atos que praticar na qualidade de incorporador. As obras resultantes somente poderão ser contratadas sob o regime de empreitada, a preço fixo ou reajustável, ou de administração, também chamada de "a preço de custo".

- O dono do terreno e também da obra, como, por exemplo, uma empresa que promove a construção de uma nova fábrica.

- Os projetistas e consultores técnicos.

- Novamente o construtor, aquele que é contratado para a execução do serviço ou obra.

- No caso de uma incorporação, o adquirente da fração ideal.

- Os gerenciadores das obras. O Project Management Institute (PMI, 2000) define gerenciamento como "a aplicação de conhecimentos, habilidades, ferramentas, e técnicas às atividades do projeto, a fim de satisfazer seus requisitos".

Outros agentes envolvidos em obras públicas e privadas são os agentes financeiros, responsáveis pelo crédito para a construção e comercialização, de caráter privado (consórcios de imóveis) ou governamentais (Caixa Econômica Federal, Banco Nacional de Desenvolvimento Econômico e Social, Companhia de Desenvolvimento Habitacional e Urbano do Estado de 
São Paulo etc.), ou ainda entidades internacionais (Banco Mundial, Banco Interamericano de Desenvolvimento, etc.), conforme citados por Abiko et al (2005).

A interface de atuação dos agentes, e suas relações contratuais com as possibilidades de uso da arbitragem estão apresentadas na figura 2.

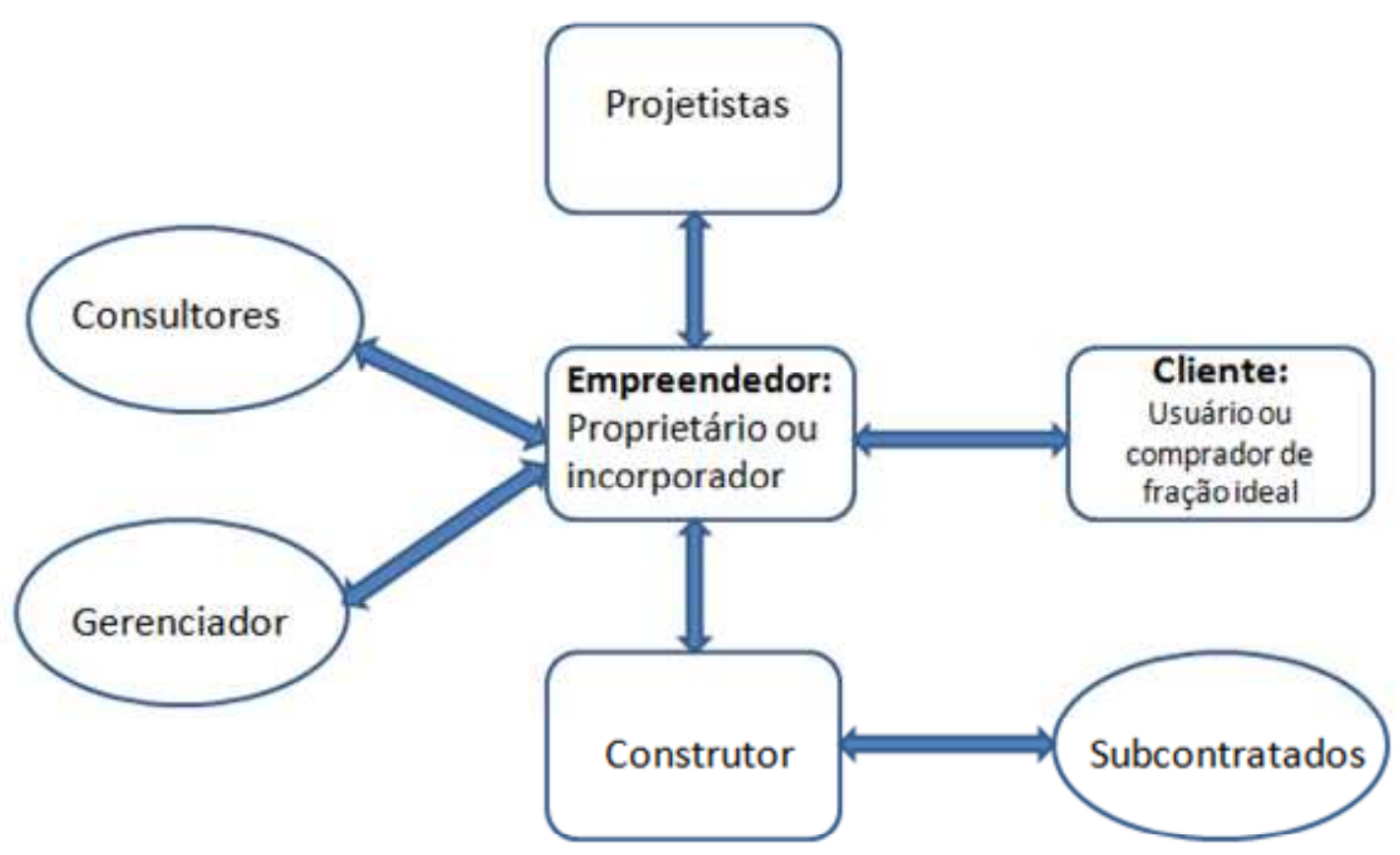

Figura 2: Interface contratual entre agentes com possibilidade de uso da arbitragem (adaptado de Melhado, 2001) 


\section{CAPÍTULO 3}

\section{A arbitragem e a construção civil}

Para uma correta e vantajosa utilização da arbitragem em disputas na construção civil é necessário conhecer a lei 9307/96 e as condições de sua aplicação, quais são as opções oferecidas pela legislação, e em quais delas é mais útil aplicá-la. Neste capítulo são apresentadas as vantagens e desvantagens de sua utilização e uma análise da lei 9307/96, com fins de entender seus mecanismos para sua correta aplicação. Ele traz assim elementos para formular a pesquisa de campo.

\subsection{Histórico da Arbitragem}

O uso da arbitragem para a solução de disputas não é algo recente. Diversos autores e fontes demonstram um histórico de sua utilização desde a antiguidade, onde a figura do árbitro já era conhecida e citada. Maia Neto (2002) descreve a utilização deste recurso 3.000 anos antes de Cristo, pelos hebreus, em uma câmara composta por três árbitros, denominada BethDiam. No Direito Romano o mesmo autor cita Quintiliano, nomeado diversas vezes como "arbiter", tendo narrado suas experiências em obra literária; na Idade Média há a citação de arbitragem em relações comerciais, por serem mais rápidas e eficientes que os tribunais oficiais. Ressalva, também, questões históricas resolvidas pela arbitragem, como a fixação da Linha de Tordesilhas por Bula publicada pelo Papa Alexandro VI, estabelecendo a linha divisória das terras das Américas entre Portugal e Espanha.

Ainda segundo Maia Neto (2002), na Bíblia, na $1^{\text {a}}$ Carta de Paulo aos Coríntios, capítulo 6, versículos 1 e 5, segundo a Tradução na Linguagem de Hoje, há as seguintes citações a um tribunal arbitral: 


\begin{abstract}
"Quando algum de vocês tem uma queixa contra um irmão na fé, como se atreve a pedir justiça a juízes que não são cristãos, em vez de pedir ao povo de Deus? Vocês não sabem que o povo de Deus julgará o mundo? [...] Será que não há entre vocês alguém com bastante sabedoria para resolver uma questão entre irmãos?"
\end{abstract}

Em 3.000 a.C. já se utilizava a arbitragem em soluções amigáveis para contendas privadas no Egito, Assíria, Babilônia, e Kheta, além de entre os hebreus, já citados, assim como as questões de limites entre cidades-estado (Polis) da Grécia, como o Tratado de Paz entre Esparta e Atenas em 445 a.C. (JESUS, 2003). Prossegue, notando que, no Brasil, a Constituição monárquica de 1824, capítulo 6º, quando tratou do poder judicial, inseriu no artigo 160 a seguinte redação, já tratando da arbitragem como modo alternativo de solução de disputas:

\footnotetext{
"Nas cíveis, e nas penas civilmente intentadas, poderão as Partes nomear Juízes Árbitros. Suas Sentenças serão executadas sem recurso, se assim o convencionarem as mesmas Partes".
}

Segundo Colaiácovo e Colaiácovo (1999), pode-se também identificar a figura do árbitro nos senhores feudais e reis, que julgavam, decretavam penas e não eram contestados. Com o surgimento do Estado Moderno de Direito, a função arbitral passou para as mãos dos juízes, que obedecem aos limites legais, necessitando sempre as suas sentenças de fundamentação.

Carvalho (2007) menciona a utilização da arbitragem no Brasil, localizando-a no Decreto №. 737 de 25/11/1850, que previa seu uso de maneira obrigatória na solução de conflitos entre comerciantes, e que foi posteriormente revogada pela lei ㄲo. 1350 de 14/09/1866, conforme transcrição:

\title{
"SECÇÃO VII
}

Do arbitramento

Art. 189. O arbitramento terá logar ou nos casos expressos no Codigo (arts. 80, 82, 95, 194, 201, 209, 215, 749, 776 e outros), ou 
quando o facto do qual depende a decisão final carece do juizo, informação, ou avaliação dos homens da arte, ou peritos.

Art. 190. Quando ás partes convier o arbitramento, devem requere-lo na acção, contestação ou allegações finaes."

A autora informa também que a "arbitragem voluntária foi mantida e citada no Código Civil de 1916 (artigos no 1.037 a 1.048), bem como no antigo código de Código de Processo Civil (arts. n. 1.031 a 1.046), que, ao ser remodelado em 1973, estabeleceu a intervenção obrigatória do Poder Judiciário, até o advento da lei ํo. 9.307/1996":

\section{"CAPÍTULOX \\ DO COMPROMISSO}

Art. 1.037. Revogado pela Lei no 9.307, de 23.9.1996.

Texto original: As pessoa capazes de contratar poderão, em qualquer tempo, louvar-se, mediante compromisso escrito, em árbitros, que lhes resolvam as pendências judiciais, ou extrajudiciais.

Art. 1.038. Revogado pela Lei oㅜ 9.307, de 23.9.1996:

Texto original: O compromisso é judicial ou extrajudicial. O primeiro pode celebrar-se por termo nos autos, perante o juizo ou tribunal, por onde correr a demanda; o segundo, por escritura pública ou particular, assinada pelas partes e duas testemunhas. (Redação dada pelo Decreto do Poder Legislativo no 3.725, de 15.1.1919)"

Em relação à utilização da arbitragem no Brasil Grion (2007) utiliza as estatísticas internacionais da Corte Internacional de Arbitragem da Câmara de Comércio Internacional ( $\mathrm{CCl}$ ) para demonstrar o aumento do uso da arbitragem pelas empresas brasileiras, conforme a tabela 1 .

\begin{tabular}{|c|c|}
\hline Ano & Quantidade de casos \\
\hline 1995 & 4 \\
\hline 1997 & 12 \\
\hline 1999 & 26 \\
\hline 2001 & 28 \\
\hline 2004 & 30 \\
\hline 2005 & 35 \\
\hline 2006 & 67 \\
\hline
\end{tabular}

Tabela 1: Quantidade de casos de arbitragens que envolvem empresas brasileiras na CCI.

(Fonte: Grion, 2007) 
Outros dados importantes levantados por Grion (2007) na Corte Internacional de Arbitragem da $\mathrm{CCl}$ foram o número de arbitragens internacionais sediadas no Brasil, que saltaram de 2 casos em 2000 para 14 em 2006, e também o número de árbitros brasileiros nomeados na $\mathrm{CCl}$, que pularam de 8 em 2000 para 31 em 2006.

\subsection{Vantagens e desvantagens da utilização da arbitragem.}

Ao promulgar a lei da arbitragem ำ 9307/96 o Estado procurou remover algumas barreiras de acesso à justiça, pois ao recorrer à justiça estatal, as partes interessadas se deparam com vários obstáculos para a solução de suas disputas. Dentre eles, cita-se:

$>$ É morosa, em função do acúmulo de processos e das formalidades processuais.

Martins, Lemes e Carmona (1999) transcrevem comentário de B.F. Garth: "No triênio 93/94/95 os 33 Ministros do Superior Tribunal de Justiça apreciaram e julgaram 106.000 processos, restando pendentes assim 51.000 sentenças judiciais. Tal fato corresponde a 3.300 sentenças por ministro ou 20 sentenças por sessão, por Ministro [...] nas Justiças Federal e Estadual tramitam em torno de 8 milhões de processos [..]." Isto demonstra a saturação existente nos Tribunais.

É onerosa, pois envolve as custas do processo, os honorários dos advogados, honorários de peritos e outros custos agregados ao processo, além de outras perdas que possam ocorrer após o início do processo judicial, tais como lucros cessantes, perdas causadas pelas paralisações de obras, inadimplências, etc.

A lentidão da justiça estatal, com processos que se arrastam por anos, também contribui para economicamente enfraquecer as partes. 
Há casos em que empresas encerram suas atividades por não receberem a tempo valores que seriam devidos e fundamentais para sua sobrevivência. Por exemplo, pode-se citar uma empreiteira com pagamentos suspensos por uma disputa, que suspende por falta de caixa os pagamentos a fornecedores, com possíveis protestos e até possível falência da empresa, e suspensão de pagamentos a empreiteiros e mão-de-obra própria, levando a paralisações das obras, novas ações de cobrança e ações na Justiça do Trabalho.

É burocrática, apega a formalidades, causando frustrações em quem nela necessita recorrer.

Martins, Lemes e Carmona (1999) indicam que o excessivo apego pelos advogados e juízes às formalidades e as nuances do direito processual os iludem, como se estivessem aplicando ao caso concreto a estrita legalidade, porém não fazendo justiça. É um contrasenso, pois a justiça é adiada ao tentar-se executá-la. As partes podem se utilizar de barreiras jurídicas baseadas nas formalidades para postergar as sentenças em casos que Ihes sejam desfavoráveis, em que tenham probabilidade de derrota no processo.

É pública, qualquer pessoa tem acesso ao processo, não há sigilo.

Segredos comerciais, técnicos e tecnológicos podem ser revelados, assim como situações potencialmente danosas à imagem e credibilidade das partes, às vezes não fundamentadas. Segundo Fagundes (2000), "o sigilo sempre preserva a estabilidade econômica das empresas ou pessoas físicas litigantes, uma vez que as discussões, restritas a contratos específicos, não são passíveis de distribuição judicial, cuja divulgação é pública. Acentua-se esta vantagem estratégica nos casos de reformulações de participação societária, em que demandas entre sócios podem gerar indesejável e nem sempre adequada quebra de confiança do público fornecedor e 
consumidor dos produtos da empresa". Na prática, pode-se exemplificar uma disputa entre incorporadora e construtora de um empreendimento residencial. Se levado a público, pode haver um efeito de falta de confiança e credibilidade na viabilidade e no término da obra, levando os compradores a impetrarem ações contra as empresas, com desistência de compra dos imóveis. Isto, se levado a público, poderia induzir a um efeito em série, com um crescer na falta de confiança e credibilidade no empreendimento e empresas e novas ações, podendo levar ao fracasso completo do empreendimento. No caso de uma arbitragem, o conflito é resolvido de maneira sigilosa, evitando-se os efeitos mencionados.

A qualidade de parte das sentenças é duvidosa, pois os juízes não são especialistas em todas as áreas, tendo que recorrer a peritos e em geral baseando-se nas conclusões destes para ditar as sentenças.

Na prática, o juiz ao não conhecer o mérito de uma matéria colocada em julgamento solicita a um perito de sua confiança que a examine, gerando um laudo técnico que responda às suas indagações, consubstanciadas em quesitos formulados pelo perito judicial, assistentes técnicos e pelas partes. Sanchez (2007) ressalva que o juiz freqüentemente aceita, sem maiores considerações, o laudo do perito oficial, podendo vir a desprezar as alegações discordantes, no caso os laudos dos assistentes técnicos, ressaltando que o Juízo tem ampla liberdade de formar seu convencimento e não se vinculando nem mesmo à prova pericial produzida pelo perito oficial. No caso do perito judicial cometer algum equívoco, isto não será percebido pelo juiz, por não ser especialista da matéria, induzindo-o ao erro.

Em resumo, as críticas que se faz à justiça estatal é que ela é morosa, onerosa, burocrática, não sigilosa e de qualidade nem sempre adequada ao tratar de temas específicos da área da Engenharia, em particular da área de construção civil e seus empreendimentos. 
$\mathrm{Na}$ esfera jurídica vários argumentos são utilizados para se justificar a utilização das cortes arbitrais. Porém, um deles é recorrente: que as partes, ao procurarem os tribunais para a solução de uma disputa, têm o objetivo de resolvê-lo de maneira justa. No entanto, os obstáculos apontados impedem o acesso à justiça, pois o simples acesso à mesma pela possibilidade de adentrar com uma ação, ou a existência de tribunais à disposição das partes, não significam que a justiça será feita. Discute-se, no fundo, o amplo direito de acesso à justiça, dificultada pelas barreiras atualmente existentes.

Neste contexto, a arbitragem foi instituída com fins de solucionar disputas de forma privada, procurando evitar as desvantagens do uso da justiça estatal.

Aparentemente, pela revisão bibliográfica, notam-se diversas vantagens ao se utilizar a arbitragem:

Rapidez, pois não existem os ritos do processo judicial, que podem levar anos para serem resolvidos.

Conforme o Capítulo V da lei 9307/96, que legisla sobre a sentença arbitral, Art. 23, define-se que "a sentença arbitral será proferida no prazo estipulado pelas partes. Nada tendo sido convencionado, o prazo para a apresentação da sentença é de seis meses, contado da instituição da arbitragem ou da substituição do árbitro. Parágrafo único. As partes e os árbitros, de comum acordo, poderão prorrogar o prazo estipulado".

Considerando-se que alguns processos chegam a demorar décadas para serem julgados pela justiça estatal, algumas vezes com falecimento das partes por problemas de idade avançada, com a perda de foco e motivo da ação, a obsolescência dos motivos que levaram a ação a ser impetrada, entre outros, os prazos curtos de uma sentença arbitral são uma grande vantagem. 
Schabbel (2002) sugere um fluxograma do procedimento arbitral, com prazo definido de 6 meses, conforme figura 1 :

\section{FLUXOGRAMA DE UMA ARBITRAGEM}

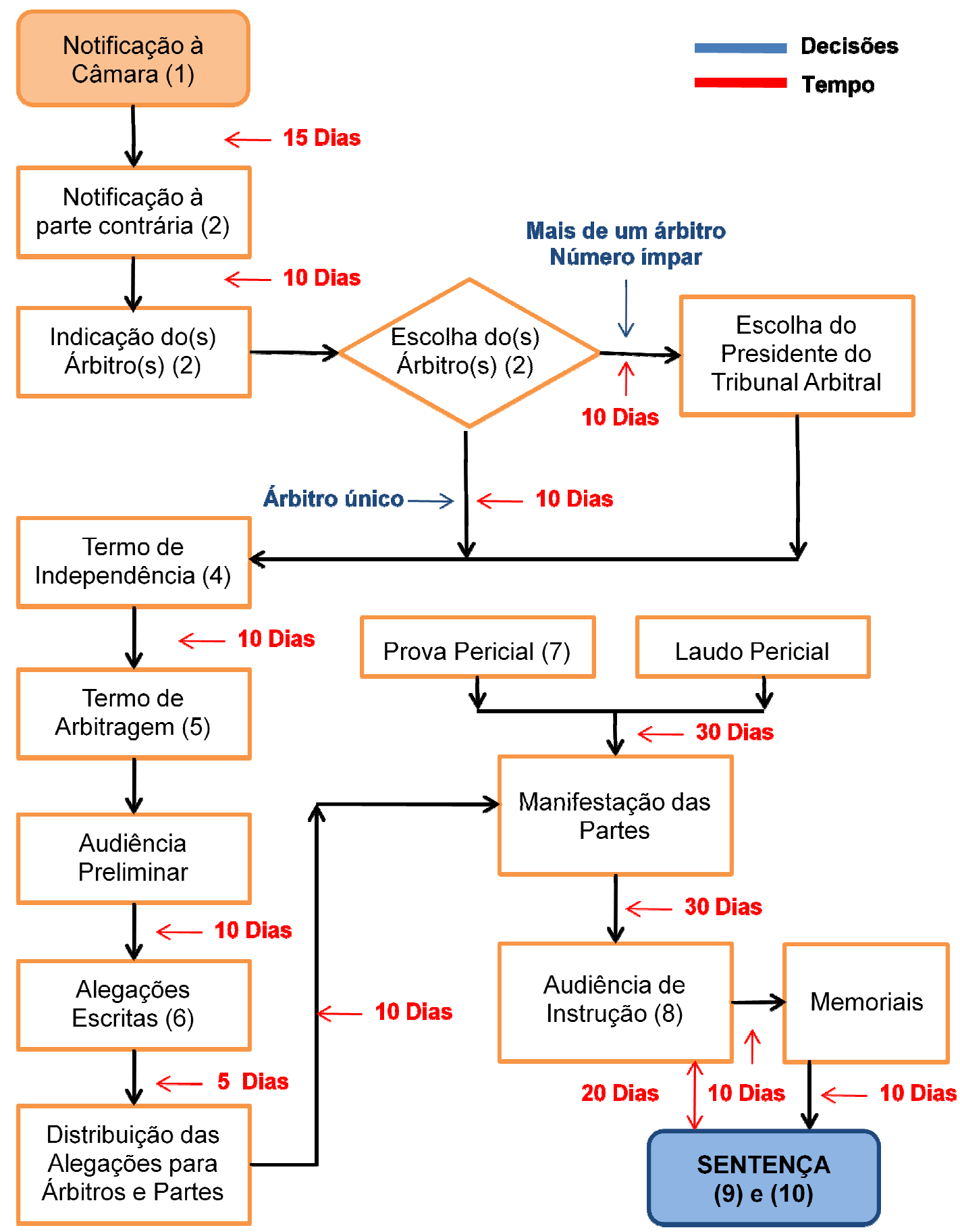

Figura 3: Fluxograma de uma arbitragem (Fonte: Schabbel, 2002). 
Flexibilidade, pois as partes decidem os termos da arbitragem, tais como número de árbitros, local, prazo, instituição que poderá dirigir o processo arbitral, dentre outras alternativas.

Sigilo, o processo é privado e discreto, sem acesso ao público, e sem divulgação de segredos estratégicos ou informações que possam vir a constranger as partes.

Chuffi (2005) cita que a arbitragem é discreta por natureza e a justiça estatal é pública por excelência.

Economia nos custos, pois embora os árbitros trabalhem sob remuneração, diversos autores, entre eles Maia Neto (2002), indicam que os custos são menores que os de um processo na justiça estatal, que englobam advogados, custas processuais, peritos.

No caso de uma das partes recorrer, levando o processo a instâncias superiores, o que não ocorre em uma arbitragem por haver uma única instância, onera-se ainda mais o processo.

Redução das formalidades, pois o processo arbitral é muito simples, com poucas regras estabelecidas pelas partes, em comparação com os procedimentos formais da justiça estatal, regidos por leis, regras e regimentos, e sem interposição de recursos

Não é impositiva, pois as partes escolhem as cláusulas arbitrais, os árbitros ou instituição de arbitragem de comum acordo, ao contrário da justiça estatal, onde o juiz não é conhecido das partes, pois depende da vara a que for distribuída o processo, ação esta tomada à revelia dos interessados.

Permite decisões com mais qualidade, pois as sentenças são fornecidas por um árbitro especialista no assunto, ao contrário do juiz que em geral é leigo, e apóia suas decisões em perícias efetuadas por sua solicitação.

Maior capacidade de solução da disputa. 
Diferentemente da justiça estatal, onde somente uma parte ganha e a outra perde, há a possibilidade do árbitro conduzir o conflito a uma solução negociada pelo fato de ter sido escolhido por ambas as partes, criando um clima favorável, ao contrário do Judiciário, que é impessoal. Isto leva também à maior aceitação da sentença proferida pelo árbitro.

A sentença tem caráter de título executivo judicial (Código de Processo Civil Art. 472), conforme artigo 31 do Capítulo V da lei 9307/96.

Isto significa que caso a parte perdedora não cumpra a decisão do árbitro esta poderá ser executada na justiça de imediato.

Em relação às desvantagens, Amaral (2010) cita o fato da sentença ser irrecorrível no caso de uma sentença arbitral ser de má qualidade, pois o árbitro pode ser um bom especialista na área técnica, mas desconhecer a legislação. Pode-se também apontar um árbitro despreparado tecnicamente, que levará a uma sentença ruim. No caso de uma sentença com vícios, esta poderá ser anulada pela justiça estatal, conforme o Artigo 32 da lei 9307/96, gerando perda de tempo e valores aos envolvidos.

Borges (2008) indica que o desconhecimento da arbitragem por empresas de porte pequeno e médio também é uma desvantagem, pois torna-se uma barreira à sua utilização, devido ao temor de se utilizar um procedimento à margem da justiça estatal. Aponta que não há tradição em seu uso no Brasil, sem instituições ou árbitros reconhecidos, levando a um sentimento de desconfiança da sua eficácia. Cita também, a cultura do litígio:

\footnotetext{
"onde um bom advogado é aquele que, através de vários recursos e artifícios levam os processos até o tribunal e por lá estes ficam anos sem julgamento. Com isso, a falta da utilização da prática arbitral inibiu a construção de jurisprudência própria, deixando o instituto disperso no mundo jurídico, adormecido nos livros e com uma minoria de adeptos."
} 
Outra desvantagem é que embora a sentença judicial seja equiparada a um título executivo judicial, caso o perdedor se negue a cumpri-la a parte vencedora deverá entrar com uma ação judicial para que seu cumprimento se efetive.

\subsection{Análise da lei 9307/1996 - condições e espectro de utilização da arbitragem}

Para uma correta avaliação das opções de uso da arbitragem em contratos de construção civil neste capítulo serão descritas as condições de utilização da arbitragem, o contexto em que pode ser utilizada, quais as opções de utilização que a lei oferece às partes, quais requisitos um árbitro deve ter, quais os procedimentos a serem seguidos, como a sentença arbitral é declarada, e como pode ser anulada, e no caso de arbitragem internacional, como pode ser homologada no Brasil.

\subsubsection{Tipos de arbitragens}

A arbitragem pode ser institucional ou ad hoc:

$>$ É institucional quando se escolhe uma instituição para a escolha do(s) árbitro(s), tais como as Câmaras Arbitrais do Instituto de Engenharia, do Instituto Brasileiro de Avaliações e Perícias na Engenharia, da Federação das Indústrias e Comércio do Estado de São Paulo.

As câmaras administram o processo, sem entrar no mérito do julgamento. Estas seguirão seus regulamentos internos, sistematizando os processos arbitrais, com maior formalismo e metodologia instituída. 
Chama-se ad hoc quando é escolhido um árbitro particular, que segue um formalismo menor e é mais direto.

Neste caso as partes envolvidas decidem as regras e critérios do julgamento arbitral, decorrendo destas a solução do conflito.

\subsubsection{Definição das pessoas que podem se valer da arbitragem e arbitragem em contratos de PPP}

A lei da arbitragem define que a ela podem valer-se as pessoas capazes de contratar, para dirimirem litígios referentes a direitos patrimoniais disponíveis, conforme transcrição do art. 1ํ:

Art. 1ำ As pessoas capazes de contratar poderão valer-se da arbitragem para dirimir litígios relativos a direitos patrimoniais disponíveis.

As pessoas a que se refere a lei podem ser físicas ou jurídicas, e entendese por pessoas capazes de contratar aquelas com capacidade de exercer seus direitos.

No caso de pessoas físicas, podem recorrer à arbitragem aquelas que adquiriram a maioridade por idade ou por emancipação. Cachapuz (2000) cita as condições em que a emancipação ocorre, levando à cessação da incapacidade: o casamento; o exercício de emprego público efetivo; a colação de grau científico em curso de ensino superior; o estabelecimento civil ou comercial com economia própria. Não possuem capacidade de exercer direitos civis as pessoas físicas incapacitadas mentalmente, presas e insolventes, dentre outras.

As pessoas jurídicas privadas podem valer-se da arbitragem, pois são capazes de contratar e podem dispor de bens e direitos patrimoniais. Quanto ao setor público, em princípio não podem utilizá-la a União, os Estados, os Municípios e as Autarquias, por não poderem dispor de seus bens. 
Existem controvérsias sobre a aplicação da arbitragem pelas empresas públicas e sociedades de economia mista.

Define-se empresa pública (ou estatal) como aquela dotada de personalidade jurídica, com patrimônio próprio e capital pertencente à União, criada por lei para explorar atividade econômica que o Governo seja levado a exercer por força de contingência ou de conveniência administrativa, conforme Decreto-Lei o․ 900/69. Seu capital é exclusivamente público, de uma ou mais entidades. Martins, Lemes e Carmona (1999) acentuam que as regras comerciais não são necessariamente aplicadas a este tipo de empresa, que algumas exploram atividades econômicas, porém outras prestam serviços públicos privativos da União ou de empresa estatal. Estas empresas foram originalmente criadas para atuar na área energética, de telecomunicações, portuária, de pesquisa e de lavra de minerais.

Quanto à sociedade de economia mista, conforme o Decreto-Lei ㄲo. 900/69 é a pessoa jurídica de direito privado que explora atividade econômica, sendo uma sociedade anônima cujas ações com direito a voto pertencem em sua maioria à União ou à entidade de administração indireta. Pode também, prestar serviços públicos.

Martins, Lemes e Carmona (1999) conceituam as atividades das sociedades públicas e de economia mista:

Continuando sob o magistério de Bandeira de Mello, podemos classificar as Empresas Públicas e as Sociedades de Economia Mista de dupla natureza: a) explora atividades econômicas, que, em princípio, competem às empresas privadas e apenas supletivamente, por razões de muita importância, é que o Estado pode vir a ser chamado a protagonizá-las; b) presta serviços públicos ou coordena a execução de obras públicas, sendo ambas as atividades induvidosamente pertinentes à esfera do Estado.

O que se discute com base nos conceitos emitidos de empresa estatal e de economia mista, e nos conceitos de suas atividades econômicas, é se os seus direitos patrimoniais são disponíveis ou não, o que definiria se podem 
se valer da arbitragem, já que sua personalidade jurídica lhe confere a capacidade de contratar. Caso haja prestação de serviço público, é matéria de interesse público; se houver atividade econômica na qual a empresa atuar nas mesmas condições que o setor privado, subentende-se que se trata de direito privado, segundo Martins, Lemes e Carmona (1999). Neste caso, a empresa pode contratar como se empresa privada fosse, sem depender de licitação pública regida pela lei 8.666/1993, porém seguindo os seus princípios. Conclui que em contratos que dispõem sobre direitos patrimoniais celebrados com particulares, a empresa estatal e a mista podem valer-se da arbitragem; já em contratos onde se fornecem serviços esta afirmação não é aplicável, ou seja, a solução de disputas pela arbitragem não é possível.

O que se nota, entretanto, é que embora diversos autores acenem para a utilização da arbitragem em contratos públicos, não há unanimidade, que os estudos convergem mais para orientações do que para uma certeza de sua utilização. Na prática, pelo fato de a sentença arbitral ser um título de execução imediata, parece haver um temor nos administradores da área pública pela utilização da arbitragem, causando resistência e desmotivação em implementar seu uso. Como foi anteriormente mencionado, é assunto controverso e foge do objetivo desta pesquisa explorar todas as nuances existentes, sendo, portanto, apenas apresentado um panorama sobre a matéria.

Há um caso explícito em lei em que o poder público pode se valer da arbitragem. Com o advento da lei no. 11.079 de 30/12/2004 que instituiu as regras para licitação e contratação das PPP, parcerias público-privadas, novamente a solução de controvérsias pelo uso da arbitragem veio à tona, pois esta lei prevê a utilização da arbitragem para a solução das disputas.

A lei $n$ ‥ 11.079/2004 define a PPP como sendo:

Art. $2^{\circ}$ Parceria público-privada é o contrato administrativo de concessão, na modalidade patrocinada ou administrativa. 
$\S 11^{0}$ Concessão patrocinada é a concessão de serviços públicos ou de obras públicas de que trata a Lei $n^{\circ} 8.987$, de 13 de fevereiro de 1995, quando envolver, adicionalmente à tarifa cobrada dos usuários contraprestação pecuniária do parceiro público ao parceiro privado.

$\S 2^{0}$ Concessão administrativa é o contrato de prestação de serviços de que a Administração Pública seja a usuária direta ou indireta, ainda que envolva execução de obra ou fornecimento e instalação de bens.

§ 3ํNão constitui parceria público-privada a concessão comum, assim entendida a concessão de serviços públicos ou de obras públicas de que trata a Lei $n^{\circ} 8.987$, de 13 de fevereiro de 1995, quando não envolver contraprestação pecuniária do parceiro público ao parceiro privado.

Namblard (1994) apud Oliveira (2005) descreve as PPP como sendo "parcerias de autoridades públicas com empresas e investidores do setor privado, com o objetivo de conceber, planificar, financiar, construir e operar projetos de infraestrutura habitualmente prestados através de mecanismos tradicionais como os contratos públicos", dentro de um contexto de escassez de recursos governamentais para a execução de obras e projetos de alto custo, em geral voltadas para infraestrutura, transporte, saneamento e saúde. A isso, conclui o autor, alia-se a condição de uma prestação de serviços de melhor qualidade, com um menor custo para a sociedade.

O capítulo I da lei 11.079/2004, Disposições Preliminares, descreve os agentes públicos que podem se valer das PPP:

Art. $1^{\circ}$ Esta Lei institui normas gerais para licitação e contratação de parceria público-privada no âmbito dos Poderes da União, dos Estados, do Distrito Federal e dos Municípios.

Parágrafo único. Esta Lei se aplica aos órgãos da Administração Pública direta, aos fundos especiais, às autarquias, às fundações públicas, às empresas públicas, às sociedades de economia mista e às demais entidades controladas direta ou indiretamente pela União, Estados, Distrito Federal e Municípios.

A PPP estabelecer-se-á conforme a referida lei, art. 9 "Antes da celebração do contrato, deverá ser constituída sociedade de propósito específico, incumbida de implantar e gerir o objeto da parceria." Isto institui a pessoa jurídica com capacidade de transacionar, sob "a forma de companhia aberta, com valores mobiliários admitidos a negociação no mercado, devendo obedecer a padrões de governança corporativa e adotar contabilidade e 
demonstrações financeiras padronizadas, conforme regulamento" transcrito da lei.

A utilização da arbitragem está expressa na lei no seguinte artigo:

Art. 11. O instrumento convocatório conterá minuta do contrato, indicará expressamente a submissão da licitação às normas desta Lei e observará, no que couber, os $\S \S 3^{\circ}$ e $4^{\circ}$ do art. 15 , os arts. 18,19 e 21 da Lei $n^{\circ} 8.987$, de 13 de fevereiro de 1995, podendo ainda prever:

- emprego dos mecanismos privados de resolução de disputas, inclusive a arbitragem, a ser realizada no Brasil e em língua portuguesa, nos termos da Lei no 9.307, de 23 de setembro de 1996, para dirimir conflitos decorrentes ou relacionados ao contrato.

Trata-se, portanto, de possibilidade indiscutível da empresa pública valer-se da arbitragem, prevista em lei. Ressalte-se que as obras regidas pelas PPP são de grande vulto e alcance social, tais como rodovias, ferrovias, metrôs, e que, portanto, a utilização da arbitragem em suas controvérsias pode gerar grande economia ao poder público, e às empresas, e benefícios à sociedade.

\subsubsection{Arbitragem de direito ou eqüidade}

A lei 9307/96 define que o julgamento arbitral poderá ser de direito ou eqüidade:

Art. $2^{\circ} \mathrm{A}$ arbitragem poderá ser de direito ou de eqüidade, a critério das partes.

$\S 1$ 10 Poderão as partes escolher, livremente, as regras de direito que serão aplicadas na arbitragem, desde que não haja violação aos bons costumes e à ordem pública. 
$\S 2^{\circ}$ Poderão, também, as partes convencionar que a arbitragem se realize com base nos princípios gerais de direito, nos usos e costumes e nas regras internacionais de comércio.

Julgar por direito significa que o julgamento dar-se-á pela aplicação das normas de direito conforme as leis.

Julgar por eqüidade significa não utilizar as regras formais de direito, onde o(s) árbitro(s) neste caso decidirá(ão) pelas suas convicções íntimas, em seu senso particular de justiça. Conforme explica Maia Neto (2002), o julgamento por eqüidade pode ser definido pela justiça do caso particular, onde o juiz percebe que a aplicação fria da lei pode levar a uma injustiça, citando ainda Edouard Couture:

"Quando encontrares a lei em conflito com a justiça, deveis ficar com a justiça."

Por ser um julgamento baseado em critérios subjetivos, a lei define que no julgamento por eqüidade deve o árbitro ter uma conduta que não agrida os bons costumes e a ordem pública. Define-se bons costumes como o padrão de comportamento baseado em valores morais em uso por uma sociedade em determinada época, que pelo consenso da população passa a ser obrigatório. Ordem pública é entendida como o estado de paz social baseada no respeito a pessoas, autoridades, instituições, bens, e também como o conjunto de normas que não podem ser alteradas pela vontade do particular (MAIA NETO, 2002).

Por princípios gerais de direito entende-se as normas elementares que servem de base a toda e qualquer ação.

\subsubsection{Cláusula Compromissória e Compromisso Arbitral}

A atribuição da utilização da arbitragem é feita pela inserção da cláusula compromissória no contrato, a qual simultaneamente institui a arbitragem e 
exclui a justiça estatal. Ocorre no momento da contratação, por livre acordo entre os contratantes. No caso de aparecer uma disputa no decorrer do empreendimento posteriormente à assinatura de um contrato que não prevê o uso da arbitragem, esta pode ser instituída a qualquer tempo pelo compromisso arbitral.

A cláusula compromissória é definida na lei 9307/96 da seguinte forma:

Capítulo II

Da Convenção de Arbitragem e seus Efeitos

Art. $3^{\circ}$ As partes interessadas podem submeter a solução de seus litígios ao juízo arbitral mediante convenção de arbitragem, assim entendida a cláusula compromissória e o compromisso arbitral.

Art. 4ำ A cláusula compromissória é a convenção através da qual as partes em um contrato comprometem-se a submeter à arbitragem os litígios que possam vir a surgir, relativamente a tal contrato.

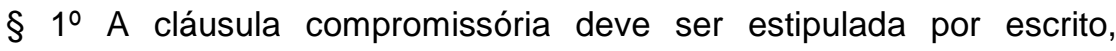
podendo estar inserta no próprio contrato ou em documento apartado que a ele se refira.

A cláusula compromissória é autônoma em relação ao contrato, significando que, mesmo que o contrato ou parte dele seja anulado, a cláusula compromissária não será anulada, podendo as partes continuarem a se valer da arbitragem.

A cláusula compromissória poderá ser cheia, na qual é indicada determinada instituição para proceder ao arbitramento, ou vazia, quando as partes simplesmente se obrigam a utilizar a arbitragem. Existem vantagens em se utilizar uma cláusula compromissória cheia:

As regras a serem seguidas já estão explícitas nos regulamentos da instituição indicada. 
Caso uma das partes resista à utilização da arbitragem, a própria instituição cuidará de aplicar as regras do rito arbitral, sem necessidade de recorrer à justiça estatal.

Caso a cláusula compromissória seja vazia, isto obrigará a parte interessada a se utilizar da arbitragem a notificar a outra parte, convocando-a a comparecer em determinado local e data para a instauração do início do processo arbitral. Havendo recusa ou o não comparecimento da parte convocada, deverá a parte que deu início ao processo recorrer à Justiça Estatal para instituir a arbitragem. Isto implica em maior burocracia para a instituição da arbitragem. Considerando-se que um dos objetivos da sua utilização é a diminuição das formalidades e rapidez da sentença, percebese que a utilização da cláusula compromissória vazia não é vantajosa.

Este rito está descrito nos Art. $6^{\circ}$ e $7^{\circ}$ do capítulo II da lei 9307/96:

Art. 6o Não havendo acordo prévio sobre a forma de instituir a arbitragem, a parte interessada manifestará à outra parte sua intenção de dar início à arbitragem, por via postal ou por outro meio qualquer de comunicação, mediante comprovação de recebimento, convocando-a para, em dia, hora e local certos, firmar o compromisso arbitral.

Parágrafo único. Não comparecendo a parte convocada ou, comparecendo, recusar-se a firmar o compromisso arbitral, poderá a outra parte propor a demanda de que trata 0 art. $7^{\circ}$ desta Lei, perante 0 órgão do Poder Judiciário a que, originariamente, tocaria o julgamento da causa.

Art. $7^{\circ}$ Existindo cláusula compromissória e havendo resistência quanto à instituição da arbitragem, poderá a parte interessada requerer a citação da outra parte para comparecer em juízo a fim de lavrar-se o compromisso, designando o juiz audiência especial para tal fim.

$\S 1^{\circ} \mathrm{O}$ autor indicará, com precisão, o objeto da arbitragem, instruindo o pedido com o documento que contiver a cláusula compromissória.

$\S 2^{\circ}$ Comparecendo as partes à audiência, o juiz tentará, previamente, a conciliação acerca do litígio. Não obtendo sucesso, tentará o juiz 
conduzir as partes à celebração, de comum acordo, do compromisso arbitral.

$\S 3^{0}$ Não concordando as partes sobre os termos do compromisso, decidirá o juiz, após ouvir o réu, sobre seu conteúdo, na própria audiência ou no prazo de dez dias, respeitadas as disposições da cláusula compromissória e atendendo ao disposto nos arts. 10 e 21 , $\S$ $2^{\circ}$, desta Lei.

§ 4ํㅗ Se a cláusula compromissória nada dispuser sobre a nomeação de árbitros, caberá ao juiz, ouvidas as partes, estatuir a respeito, podendo nomear árbitro único para a solução do litígio.

$\S 5^{\circ} \mathrm{A}$ ausência do autor, sem justo motivo, à audiência designada para a lavratura do compromisso arbitral, importará a extinção do processo sem julgamento de mérito.

§ 6ำ Não comparecendo o réu à audiência, caberá ao juiz, ouvido o autor, estatuir a respeito do conteúdo do compromisso, nomeando árbitro único.

$\S 7^{\circ}$ A sentença que julgar procedente o pedido valerá como compromisso arbitral.

Deve-se sempre detalhar ao máximo as condições de utilização na cláusula compromissória inserida em um contrato. Maia Neto (2002) sugere um modelo de cláusula compromissória:

Toda e qualquer controvérsia que surgir entre os contratantes, em relação a aplicação, duração, validade, interpretação ou execução do presente contrato, bem como qualquer causa referente ao seu objeto, será resolvido pela arbitragem, conforme a Lei 9307/96, de acordo com as normas de Regulamento de Arbitragem da Câmara Arbitral da "XX" Arbitral, por " $X$ " árbitro(s) e seus respectivos suplentes, nomeados conforme o disposto no referido regulamento. A arbitragem estará sujeita às leis do Brasil, e será conduzida no idioma Português.

Uma cláusula compromissória eficiente deverá determinar:

Que todas as disputas sejam resolvidas pela arbitragem; 
Independência da cláusula, garantindo que mesmo que uma das partes não concorde com o uso da arbitragem o processo arbitral continuará;

As regras do processo arbitral, tais como local, prazo máximo de sentença, indicação dos árbitros em termos de número e qualificação, língua do processo e outros.

O compromisso arbitral é estabelecido em caso de aparecimento de disputas durante a execução do contrato, indicando a arbitragem para a solução da disputa. Pode ser judicial, no caso de já haver uma ação em curso, ou extrajudicial, celebrado em compromisso particular ou público.

A lei 9307/96 assim descreve e regulamenta o compromisso arbitral:

Art. 9ㅇ 0 compromisso arbitral é a convenção através da qual as partes submetem um litígio à arbitragem de uma ou mais pessoas, podendo ser judicial ou extrajudicial.

$\S 1^{\circ} \mathrm{O}$ compromisso arbitral judicial celebrar-se-á por termo nos autos, perante o juízo ou tribunal, onde tem curso a demanda.

$\S 2^{\circ} \mathrm{O}$ compromisso arbitral extrajudicial será celebrado por escrito particular, assinado por duas testemunhas, ou por instrumento público.

Art. 10. Constará, obrigatoriamente, do compromisso arbitral:

I - o nome, profissão, estado civil e domicílio das partes;

II - o nome, profissão e domicílio do árbitro, ou dos árbitros, ou, se for o caso, a identificação da entidade à qual as partes delegaram a indicação de árbitros;

III - a matéria que será objeto da arbitragem; e

IV - o lugar em que será proferida a sentença arbitral.

Art. 11. Poderá, ainda, o compromisso arbitral conter:

I - local, ou locais, onde se desenvolverá a arbitragem; 
II - a autorização para que o árbitro ou os árbitros julguem por eqüidade, se assim for convencionado pelas partes;

III - o prazo para apresentação da sentença arbitral;

IV - a indicação da lei nacional ou das regras corporativas aplicáveis à arbitragem, quando assim convencionarem as partes;

V - a declaração da responsabilidade pelo pagamento dos honorários e das despesas com a arbitragem; e

VI - a fixação dos honorários do árbitro, ou dos árbitros.

Parágrafo único. Fixando as partes os honorários do árbitro, ou dos árbitros, no compromisso arbitral, este constituirá título executivo extrajudicial; não havendo tal estipulação, o árbitro requererá ao órgão do Poder Judiciário que seria competente para julgar, originariamente, a causa que os fixe por sentença.

É importante notar a diferença temporal em que a opção pela arbitragem é escolhida. Ao se optar pela inserção da cláusula compromissória no contrato o objeto da disputa é indefinido, pois não ocorreu ainda nenhum conflito ou disputa. Quando o compromisso arbitral é utilizado significa que já há uma disputa em andamento, e neste caso o objeto do processo arbitral já é definido e claro.

O compromisso arbitral deverá, segundo a lei, conter elementos obrigatórios e opcionais. Os elementos obrigatórios estão descritos no artigo 10, itens I, II, III e IV. Os elementos opcionais estão descritos no artigo 11, itens I, II, III, IV, V e VI.

O compromisso arbitral poderá se extinguir por recusa dos árbitros em aceitar a nomeação, falecimento ou impossibilidade de voto desde que as partes não aceitem substituto ou ainda expiração do prazo definido para a sentença arbitral, conforme determina o Artigo 12:

Art. 12. Extingue-se o compromisso arbitral: 
I - escusando-se qualquer dos árbitros, antes de aceitar a nomeação, desde que as partes tenham declarado, expressamente, não aceitar substituto;

II - falecendo ou ficando impossibilitado de dar seu voto algum dos árbitros, desde que as partes declarem, expressamente, não aceitar substituto; e

III - tendo expirado o prazo a que se refere o art. 11, inciso III, desde que a parte interessada tenha notificado o árbitro, ou o presidente do tribunal arbitral, concedendo-Ihe o prazo de dez dias para a prolação e apresentação da sentença arbitral.

\subsubsection{Escolha dos árbitros}

São qualidades desejadas nos árbitros para julgar o assunto objeto do litígio, que conseqüentemente economizará tempo, custos e conferirá qualidade à sentença, conforme Maia Neto (2002), Almeida (2002) e Sanchez (2007):

Imparcialidade - o árbitro não deverá procurar favorecer nenhuma das partes.

Confiança das partes, o que dará credibilidade à sentença.

Independência - o árbitro não deverá ter qualquer vinculação com as partes.

Neutralidade - 0 árbitro não poderá ter idéias pré-concebidas sobre o assunto a ser julgado.

Eficiência - o árbitro deverá ser capaz de produzir a sentença arbitral.

Discrição - o árbitro deverá exercer conduta reservada que preserve as partes. 
Notório saber - o árbitro deverá ter um conhecimento profundo sobre a matéria a ser julgada em um sentido e contexto mais amplo que o da própria ação.

Qualificação técnica - o árbitro deverá conhecer em profundidade 0 assunto abordado sob a ótica técnica.

Obrigatoriamente o árbitro deve ser pessoa física e não jurídica, e ter capacidade civil. Podem-se utilizar pessoas jurídicas na qualidade de instituições para a montagem dos tribunais, porém as pessoas físicas serão os árbitros.

A lei exige número ímpar de árbitros com fins de se evitar empate ao votarse a sentença arbitral, no caso de serem indicados mais de um árbitro. Havendo mais de um árbitro, haverá um presidente da corte arbitral, eleito pelos outros árbitros. No caso de não haver consenso, eleger-se-á o mais idoso. É opcional a escolha de um secretário pelo presidente eleito.

Em relação à quantidade de árbitros, deve-se avaliar quais as vantagens de se indicar um ou vários árbitros. Um único árbitro trará agilidade e menor custo. Por outro lado, decidirá isoladamente, sem outros pareceres ou opiniões. Utilizando-se mais de um árbitro a decisão será de consenso, porém de maior custo, e menos ágil.

As regras de escolhas dos árbitros estão descritas no capítulo III da lei 9307/96:

Dos Árbitros

Art. 13. Pode ser árbitro qualquer pessoa capaz e que tenha a confiança das partes.

$\S 1^{\circ}$ As partes nomearão um ou mais árbitros, sempre em número ímpar, podendo nomear, também, os respectivos suplentes.

§ 2 Quando as partes nomearem árbitros em número par, estes estão autorizados, desde logo, a nomear mais um árbitro. Não havendo acordo, requererão as partes ao órgão do Poder Judiciário a que 
tocaria, originariamente, o julgamento da causa a nomeação do árbitro, aplicável, no que couber, o procedimento previsto no art. $7^{\circ}$ desta Lei.

$\S 3^{\circ}$ As partes poderão, de comum acordo, estabelecer o processo de escolha dos árbitros, ou adotar as regras de um órgão arbitral institucional ou entidade especializada.

§ 4ํㅗㄴ Sendo nomeados vários árbitros, estes, por maioria, elegerão o presidente do tribunal arbitral. Não havendo consenso, será designado presidente o mais idoso.

$\S 5^{\circ} \bigcirc$ árbitro ou 0 presidente do tribunal designará, se julgar conveniente, um secretário, que poderá ser um dos árbitros.

$\S 6^{\circ}$ No desempenho de sua função, o árbitro deverá proceder com imparcialidade, independência, competência, diligência e discrição.

$\S 7$ Poderá 0 árbitro ou 0 tribunal arbitral determinar às partes 0 adiantamento de verbas para despesas e diligências que julgar necessárias.

Os árbitros poderão ser impedidos de cumprir seus deveres no caso de terem relações com uma das partes, e dúvidas quanto à sua imparcialidade e independência. Os próprios árbitros indicados têm o dever de revelar se há qualquer fato impeditivo de assumirem a causa arbitral, tais como parentesco, relações legais com uma das partes tais como ter sido testemunha, perito, ser amigo íntimo, ser devedor ou credor de uma das partes e outros motivos descritos nos artigos 134 e 135 do Código de Processo Civil, conforme aponta Maia Neto (2002).

A lei 9307/96 assim descreve as regras de impedimento do juiz arbitral:

Art. 14. Estão impedidos de funcionar como árbitros as pessoas que tenham, com as partes ou com o litígio que Ihes for submetido, algumas das relações que caracterizam os casos de impedimento ou suspeição de juízes, aplicando-se-lhes, no que couber, os mesmos deveres e responsabilidades, conforme previsto no Código de Processo Civil.

$\S 1^{\circ}$ As pessoas indicadas para funcionar como árbitro têm o dever de revelar, antes da aceitação da função, qualquer fato que denote dúvida justificada quanto à sua imparcialidade e independência. 
$\S 2^{\circ} \mathrm{O}$ árbitro somente poderá ser recusado por motivo ocorrido após sua nomeação. Poderá, entretanto, ser recusado por motivo anterior à sua nomeação, quando:

a) não for nomeado, diretamente, pela parte; ou

b) o motivo para a recusa do árbitro for conhecido posteriormente à sua nomeação.

Art. 15. A parte interessada em argüir a recusa do árbitro apresentará, nos termos do art. 20, a respectiva exceção, diretamente ao árbitro ou ao presidente do tribunal arbitral, deduzindo suas razões e apresentando as provas pertinentes.

Parágrafo único. Acolhida a exceção, será afastado o árbitro suspeito ou impedido, que será substituído, na forma do art. 16 desta Lei.

Art. 16. Se o árbitro escusar-se antes da aceitação da nomeação, ou, após a aceitação, vier a falecer, tornar-se impossibilitado para o exercício da função, ou for recusado, assumirá seu lugar o substituto indicado no compromisso, se houver.

§ 1N Não havendo substituto indicado para o árbitro, aplicar-se-ão as regras do órgão arbitral institucional ou entidade especializada, se as partes as tiverem invocado na convenção de arbitragem.

$\S 2^{\circ}$ Nada dispondo a convenção de arbitragem e não chegando as partes a um acordo sobre a nomeação do árbitro a ser substituído, procederá a parte interessada da forma prevista no art. $7^{\circ}$ desta Lei, a menos que as partes tenham declarado, expressamente, na convenção de arbitragem, não aceitar substituto.

Os árbitros respondem por seus atos no tribunal arbitral sendo equiparados aos funcionários públicos em termos penais, conforme artigos 312 a 327 (MAIA NETO, 2002). São considerados atos suscetíveis a penas que variam de multa a até oito anos de reclusão, dentre outros, o roubo ou apropriação de bens e numerário direta ou indiretamente, aceitar vantagens indevidas, retardar ou deixar de praticar ato do ofício, conforme o artigo 17: 
Art. 17. Os árbitros, quando no exercício de suas funções ou em razão delas, ficam equiparados aos funcionários públicos, para os efeitos da legislação penal.

O árbitro é um juiz de fato, a sua sentença não necessita de homologação judicial e é título executivo, podendo ser cobrada de imediato, pois para a sentença arbitral não há possibilidade de se recorrer da sentença, conforme o artigo 18:

Art. 18. O árbitro é juiz de fato e de direito, e a sentença que proferir não fica sujeita a recurso ou a homologação pelo Poder Judiciário.

\subsubsection{Procedimentos}

Processo, no contexto legal, é definido por Carnelutti (1956) apud Cachapuz (2000) como a seqüência de atos que se realizam para a composição da disputa.

Procedimento é a seqüência de atos coordenados, seguindo-se regras préestabelecidas e interligadas com a finalidade de organizar e concluir o processo, conforme descrito no capítulo IV da lei 9307/96. No caso em estudo, a solução da disputa estabelecida pela arbitragem. O procedimento arbitral está descrito na figura 3, p. 43.

O processo arbitral inicia-se efetivamente quando a nomeação for aceita pelo(s) árbitro(s). Caso este(s) entenda $(\mathrm{m})$ que existam questões sobre a convenção arbitral, deverá neste instante requerer às partes os esclarecimentos necessários, e em conjunto com estas juntar ao processo arbitral um adendo elaborado em conjunto, conforme o capítulo IV da lei 9307/96:

Art. 19. Considera-se instituída a arbitragem quando aceita a nomeação pelo árbitro, se for único, ou por todos, se forem vários.

Parágrafo único. Instituída a arbitragem e entendendo o árbitro ou o tribunal arbitral que há necessidade de explicitar alguma questão 
disposta na convenção de arbitragem, será elaborado, juntamente com as partes, um adendo, firmado por todos, que passará a fazer parte integrante da convenção de arbitragem.

Por questões, conforme Almeida (2002), entende-se:

"as omissões, obscuridades, contradições, ou ainda falhas, para se utilizar de um termo de conotação geral, no texto da convenção de arbitragem, capazes de infundir dúvida em seu espírito, capazes de levá-lo a cometer equívocos em seu julgamento".

Dentro dos procedimentos arbitrais cabe às partes neste instante levantar, caso existam, suspeições e impedimentos sobre os árbitros, ou sobre a própria convenção arbitral, tais como omissões, incongruências, pontos obscuros, contradições, etc. O árbitro poderá ser substituído, no caso de suspeição ou impedimento, e caso haja nulidade, invalidade ou ineficácia da convenção arbitral a justiça estatal julgará a causa.

$\mathrm{Na}$ convenção de arbitragem as partes já determinaram alguns procedimentos, que deverão ser seguidos, tais como número de árbitros, local do julgamento arbitral, língua em que o processo tramitará, e outros. Os procedimentos adicionais serão os de um órgão arbitral, no caso de ser institucional, ou serão reguladas pelo(s) árbitro(s), no caso de ser ad hoc. Conforme está na lei 9307/96:

Art. 21. A arbitragem obedecerá ao procedimento estabelecido pelas partes na convenção de arbitragem, que poderá reportar-se às regras de um órgão arbitral institucional ou entidade especializada, facultandose, ainda, às partes delegar ao próprio árbitro, ou ao tribunal arbitral, regular o procedimento.

$\S 1^{\circ}$ Não havendo estipulação acerca do procedimento, caberá ao árbitro ou ao tribunal arbitral discipliná-lo.

$\S 2^{\circ}$ Serão, sempre, respeitados no procedimento arbitral os princípios do contraditório, da igualdade das partes, da imparcialidade do árbitro e de seu livre convencimento. 
No parágrafo $2^{\circ}$ garantem-se alguns princípios legais, que em conjunto dão equilíbrio ao processo arbitral:

Contraditório, que vem a ser a igualdade de manifestação e participação das partes dentro do processo.

Da igualdade das partes, ou isonomia, que dispões que todos são iguais perante a lei, independentes de sua capacidade econômica, capacidades pessoais, cargo, etc.

Imparcialidade do árbitro, já discutido anteriormente.

Livre convencimento, pelo qual o árbitro tem liberdade para formar sua sentença baseado nas provas apresentadas, seguindo um raciocínio lógico.

As partes podem se utilizar de advogados para representá-los perante a corte arbitral, conforme o parágrafo 3ํㅜ do Artigo 21 da lei 9307/96. Deve-se considerar que os advogados têm o conhecimento das leis, dos ritos, e estão emocionalmente distantes da disputa, sendo vantajosa e aconselhável a sua contratação. Conforme descreve a lei 9307/96:

$\S 3^{\circ}$ As partes poderão postular por intermédio de advogado, respeitada, sempre, a faculdade de designar quem as represente ou assista no procedimento arbitral.

O parágrafo $4^{\circ}$ do Artigo 21 da lei 9307/96 obriga o(s) árbitro(s) a convocar(em) as partes a tentar(em) uma conciliação, agindo como mediador(es). Levando-se em conta que um dos objetivos da lei é justamente a rapidez do julgamento, a tentativa de conciliação é extremamente importante, podendo levar ao término do conflito já no início dos trabalhos arbitrais. É inegável vantagem, pois ocorre de maneira pacífica, de comum acordo entra as partes, sem a interferência de um terceiro com poder de decisão, no caso o árbitro. Não existirão derrotados ou vencedores neste caso. Além disso, os gastos serão menores. Caso haja 
o acordo, a arbitragem encerra-se com uma sentença arbitral. Conforme está na lei:

$\S 4^{\circ}$ Competirá ao árbitro ou ao tribunal arbitral, no início do procedimento, tentar a conciliação das partes, aplicando-se, no que couber, 0 art. 28 desta Lei.

O artigo 28 diz:

Art. 28. Se, no decurso da arbitragem, as partes chegarem a acordo quanto ao litígio, o árbitro ou o tribunal arbitral poderá, a pedido das partes, declarar tal fato mediante sentença arbitral, que conterá os requisitos do art. 26 desta Lei.

Cabe ao(s) árbitro(s) utilizando os poderes que a lei lhe(s) confere conduzir o processo arbitral dentro dos procedimentos previstos, inclusive quanto à produção de provas. Poderá(ão) convocar testemunhas para conceder depoimentos, requisitar provas periciais, solicitar documentações para esclarecimentos, e outras atividades que ajudem a elucidar o conflito. Não deverá(ão) o(s) árbitro(s) se esquecer de documentar todas as atividades, evitando-se desta maneira a anulação do processo arbitral. Caso necessário, se uma das partes se recusar a comparecer a uma audiência arbitral, poderá(ao) o(s) árbitro(s) solicitar à justiça estatal que conduza a parte à audiência previamente agendada. No caso do não atendimento das convocações por uma das partes, poderá(ao) o(s) árbitro(s) julgar à revelia, sem a presença da parte rebelde. Almeida (2002) define revelia como ausência de defesa. Estas considerações estão descritas na lei 9307/96:

Art. 22. Poderá o árbitro ou o tribunal arbitral tomar o depoimento das partes, ouvir testemunhas e determinar a realização de perícias ou outras provas que julgar necessárias, mediante requerimento das partes ou de ofício.

$\S 1^{\circ} \mathrm{O}$ depoimento das partes e das testemunhas será tomado em local, dia e hora previamente comunicados, por escrito, e reduzido a termo, assinado pelo depoente, ou a seu rogo, e pelos árbitros.

$\S 2^{\circ}$ Em caso de desatendimento, sem justa causa, da convocação para prestar depoimento pessoal, o árbitro ou o tribunal arbitral levará 
em consideração o comportamento da parte faltosa, ao proferir sua sentença; se a ausência for de testemunha, nas mesmas circunstâncias, poderá o árbitro ou o presidente do tribunal arbitral requerer à autoridade judiciária que conduza a testemunha renitente, comprovando a existência da convenção de arbitragem.

$\S 3^{0}$ A revelia da parte não impedirá que seja proferida a sentença arbitral.

$\S 4^{\circ}$ Ressalvado o disposto no $\S 2^{\circ}$, havendo necessidade de medidas coercitivas ou cautelares, os árbitros poderão solicitá-las ao órgão do Poder Judiciário que seria, originariamente, competente para julgar a causa.

$\S 5^{\circ}$ Se, durante o procedimento arbitral, um árbitro vier a ser substituído fica a critério do substituto repetir as provas já produzidas.

\subsubsection{Sentença Arbitral}

A sentença arbitral é o ato final do processo, onde, após a análise das documentações e das provas e após ouvir testemunhas, o árbitro emite sua decisão, encerrando a disputa. É definitiva e irrecorrível, não cabendo recursos, e é título executivo. Conforme a lei 9307/96 o prazo para que o árbitro declare a sentença é de seis meses, podendo este prazo ser modificado de comum acordo entre as partes:

Da Sentença Arbitral

Art. 23. A sentença arbitral será proferida no prazo estipulado pelas partes. Nada tendo sido convencionado, o prazo para a apresentação da sentença é de seis meses, contado da instituição da arbitragem ou da substituição do árbitro.

Parágrafo único. As partes e os árbitros, de comum acordo, poderão prorrogar o prazo estipulado. 
Sua apresentação deverá ser escrita, por maioria dos votos, no caso de mais de um árbitro. No caso de empate, o voto do presidente do tribunal arbitral decidirá a sentença. Se algum árbitro não concordar com a sentença, poderá separadamente apresentar seus pontos de divergência. Caso existam dúvidas se os direitos são disponíveis ou não, condição fundamental para o processo arbitral, o mesmo é suspenso e as partes são encaminhadas à justiça estatal. Conforme a lei 9307/96:

Art. 24. A decisão do árbitro ou dos árbitros será expressa em documento escrito.

§ 1ำ Quando forem vários os árbitros, a decisão será tomada por maioria. Se não houver acordo majoritário, prevalecerá o voto do presidente do tribunal arbitral.

$\S 2^{\circ}$ O árbitro que divergir da maioria poderá, querendo, declarar seu voto em separado.

Art. 25. Sobrevindo no curso da arbitragem controvérsia acerca de direitos indisponíveis e verificando-se que de sua existência, ou não, dependerá o julgamento, o árbitro ou o tribunal arbitral remeterá as partes à autoridade competente do Poder Judiciário, suspendendo o procedimento arbitral.

Parágrafo único. Resolvida a questão prejudicial e juntada aos autos a sentença ou acórdão transitados em julgado, terá normal seguimento a arbitragem.

Para evitar a anulação da sentença, esta deverá conter alguns requisitos obrigatórios estipulados na lei:

O relatório, com a qualificação das partes, e um resumo das ocorrências havidas no decorrer do processo.

A fundamentação da sentença, com o exame das questões, declarando se o julgamento foi feito por eqüidade.

O dispositivo, com a conclusão das questões formuladas, e a declaração da sentença. 
Data e local da sentença.

Conforme diz a lei 9307/96:

Art. 26. São requisitos obrigatórios da sentença arbitral:

I - o relatório, que conterá os nomes das partes e um resumo do litígio;

II - os fundamentos da decisão, onde serão analisadas as questões de fato e de direito, mencionando-se, expressamente, se os árbitros julgaram por eqüidade;

III - o dispositivo, em que os árbitros resolverão as questões que lhes forem submetidas e estabelecerão o prazo para o cumprimento da decisão, se for o caso; e

IV - a data e o lugar em que foi proferida.

Parágrafo único. A sentença arbitral será assinada pelo árbitro ou por todos os árbitros. Caberá ao presidente do tribunal arbitral, na hipótese de um ou alguns dos árbitros não poder ou não querer assinar a sentença, certificar tal fato.

Na sentença arbitral, segundo o artigo 27 da lei, deverá o árbitro definir os custos e despesas com o processo arbitral, que caberá ao perdedor, podendo também exigir um valor por litigância de má-fé, quando uma das partes tenta alterar, tumultuar, resistir, mentir ou utilizar de outros modos para que a verdade não transpareça.

Conforme o artigo 28 da lei, se durante o processo arbitral o conflito for resolvido por um acordo, caberá ao juiz arbitral declarar isto mediante uma sentença, contendo os requisitos do artigo 26.

Ao se proferir a sentença arbitral, o árbitro ou o presidente do tribunal arbitral simultaneamente encerrará o processo arbitral, e deverá enviar cópias da sentença às partes, que terão cinco dias contados do recebimento para solicitar ao árbitro que corrija erro material da sentença, ou esclareça algum ponto obscuro ou omitido, dúvida ou contradição da sentença. $O$ árbitro ou o presidente do tribunal arbitral terá o prazo de dez dias para 
aditar a sentença e notificar as partes. Como já comentado anteriormente, a sentença arbitral torna-se titulo executivo neste estágio.

A sentença arbitral poderá ser anulada, apenas pelo Poder Judiciário, se houverem as condições dispostas no artigo 32 da lei:

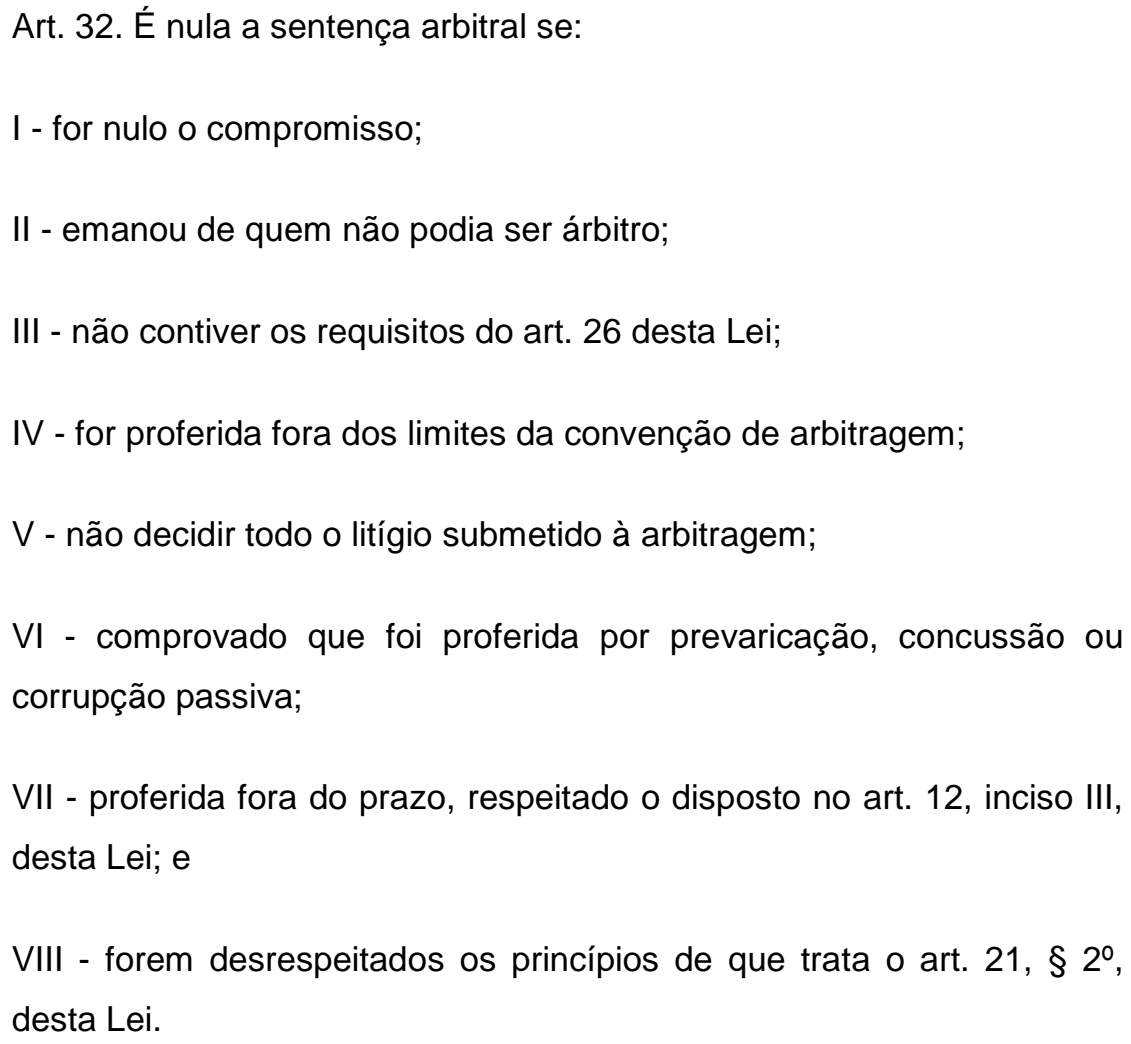

As razões para a nulidade são claras, cabendo esclarecer que o inciso VII refere-se aos princípios do contraditório, da igualdade das partes, da imparcialidade do árbitro e de seu livre convencimento. Para que a anulação ocorra, deverá a parte interessada ingressar com ação no Poder Judiciário no prazo máximo de noventa dias após a declaração da sentença arbitral.

A sentença será anulada totalmente no caso conforme descrito no artigo 32 da lei:

I - for nulo o compromisso;

II - emanou de quem não podia ser árbitro;

$\mathrm{VI}$ - comprovado que foi proferida por prevaricação, concussão ou corrupção passiva; 
VII - proferida fora do prazo, respeitado o disposto no art. 12, inciso III, desta Lei; e

VIII - forem desrespeitados os princípios de que trata o art. $21, \S 2^{\circ}$, desta Lei.

A sentença terá nulidade parcial se, conforme descrito no artigo 32 da lei:

$$
\begin{aligned}
& \text { III - não contiver os requisitos do art. } 26 \text { desta Lei; } \\
& \text { IV - for proferida fora dos limites da convenção de arbitragem; } \\
& \text { V - não decidir todo o litígio submetido à arbitragem. }
\end{aligned}
$$

Neste caso, o processo poderá ser aproveitado, devendo o árbitro proferir outra sentença, sem vícios.

\subsubsection{Homologação de Sentença Arbitral Estrangeira}

O contexto econômico mundial atual está profundamente ligado à globalização. Colaiácovo e Colaiácovo (1999) afirmam que a interdependência e integração entre as diferentes economias nacionais e os agentes econômicos vem se incrementando nas últimas décadas, com suporte de um grande avanço tecnológico nas áreas de transportes e de comunicações. As empresas globais agem como se o mundo fosse uma única região, incluindo-se neste caso as grandes empresas construtoras e empreiteiras que se dedicam a obras públicas.

As grandes empresas construtoras brasileiras tradicionalmente há muito anos já atuam no exterior, construindo ferrovias, barragens, hidrelétricas, obras de infraestrutura, obras de saneamento, rodovias, etc. As possibilidades de conflitos e disputas são uma realidade neste setor, sendo normal que elas estipulem a arbitragem internacional para solucioná-los. $O$ fato das sentenças arbitrais serem reconhecidas mesmo que promulgadas 
no exterior traz segurança para as empresas construtoras. Para que a sentença arbitral seja válida no Brasil, a lei 9307/96 estipula que:

Do Reconhecimento e Execução de Sentenças

Arbitrais Estrangeiras

Art. 34. A sentença arbitral estrangeira será reconhecida ou executada no Brasil de conformidade com os tratados internacionais com eficácia no ordenamento interno e, na sua ausência, estritamente de acordo com os termos desta Lei.

Parágrafo único. Considera-se sentença arbitral estrangeira a que tenha sido proferida fora do território nacional.

Art. 35. Para ser reconhecida ou executada no Brasil, a sentença arbitral estrangeira está sujeita, unicamente, à homologação do Supremo Tribunal Federal.

Em 2004, pela Emenda Constitucional № 45, foi transferida ao Supremo Tribunal de Justiça (STJ) a competência para homologação de laudos arbitrais estrangeiros, o que levou à agilização do processo.

A lei se refere também a tratados internacionais cuja conformidade está interligada a execução no Brasil de sentença arbitral estrangeira. Martins, Lemes e Carmona (1999) notam que o Brasil ratificou o Protocolo de Genebra sobre Cláusulas Arbitrais em 1923, a Convenção Interamericana sobre Arbitragem Internacional, conhecida como Convenção do Panamá, em 1975, e a Convenção de Montevidéu em 1995. Mais recentemente, em 2002, o Brasil reconheceu a New York Convention de 1958, que aproximadamente 140 países já reconheceram e assinaram, a qual é um tratado internacional para reconhecimento, homologação e execução de sentenças arbitrais. 


\section{CAPÍTULO 4}

\section{Resultados da Pesquisa}

Neste capítulo são apresentadas as análises isoladas das informações coletadas pelas entrevistas em órgão institucionais arbitrais, empresas construtoras e escritórios de advocacia, e uma análise integrada de todas as informações, com o objetivo de formar um panorama da utilização da arbitragem como forma de solução de disputas em empreendimentos de construção civil.

\subsection{Análise da pesquisa em órgãos arbitrais institucionais}

As entrevistas lastreadas em questionários estruturados foram efetuadas em três órgãos institucionais arbitrais da cidade de São Paulo, os quais são nomeados pelas letras $\mathrm{O} 1, \mathrm{O} 2$ e $\mathrm{O} 3$ de maneira aleatória. No APENDICE 1 estão as transcrições das perguntas e respostas das entrevistas em cada órgão institucional arbitral.

Os resultados das entrevistas indicam:

- É relevante a quantidade de casos citados de arbitragens que envolvem empresas construtoras em relação ao total de casos, sendo citado que nos dois órgãos de maior porte (O1 e O3) estes correspondem respectivamente a $40 \%$ e $30 \%$ dos casos totais.

- A utilização da arbitragem é baseada exclusivamente em cláusulas compromissórias, não havendo quase uso de compromisso arbitral; apenas o órgão institucional arbitral $\mathrm{O} 1$ indicou $\mathrm{o}$ uso deste instrumento num percentual ínfimo, conforme informado, de $1 \%$. 
- Somente em contratos privados a arbitragem foi utilizada; não houve nenhum caso de utilização em contratos de PPP e contratos administrativos.

- Há um equilíbrio entre os sub-setores de infraestrutura e edificações em relação à utilização da arbitragem.

- As disputas predominantes são entre empresa construtora (contratada) e o cliente (contratante), embora ocorram também entre empresa construtora e subcontratados. Nota-se que no órgão institucional arbitral $\mathrm{O} 2$, dos casos que envolvem empreendimentos de construção civil, metade corresponde a empresas construtoras e subcontratados, tendo como explicação o fato de que as custas neste órgão são menores que nos órgão 01 e O3, facilitando a utilização da arbitragem em contratos de valores menores que os tratados nas câmaras de maior porte.

- As câmaras arbitrais não são utilizadas para solução de disputas entre incorporadoras e adquirentes de frações ideais, pois o código do consumidor é mais adequado para solucionar este tipo de conflito, além do alto custo existente na arbitragem.

- São citados como fatores estimulantes da utilização da arbitragem pelas empresas construtoras a rapidez de resolução do conflito, o sigilo e a qualidade da sentença. Desestimula, no entanto, o alto custo do processo arbitral. Em alguns casos as empresas construtoras deixam de utilizar a arbitragem por desconhecimento da lei e de suas vantagens, ou por que há um interesse em postergar a resolução do conflito.

- Segundo os órgãos arbitrais, as empresas construtoras não notam desvantagens na utilização da arbitragem, avaliam favoravelmente o seu uso, em especial porque a questão se resolve em um prazo muito mais curto que na justiça estatal, porém contestam os custos altos do processo arbitral. 
- O prazo estipulado em lei, de 180 dias, raramente é cumprido. O órgão 01 informou que o prazo médio é de 14 meses e o órgão O2 que é de 12 meses.

- Os órgãos arbitrais consideram que a lei 9306/97 é suficiente, não necessita de alterações; que deve ser feito um trabalho de divulgação para incrementar seu uso; que nos dois últimos anos houve um aumento de uso da arbitragem de forma expressiva.

$\mathrm{Na}$ tabela 2 estão transcritas as entrevistas com os órgãos institucionais arbitrais.

\begin{tabular}{|c|c|c|c|}
\hline \multirow{2}{*}{ Questão } & \multicolumn{3}{|c|}{ Órgãos arbitrais institucionais } \\
\hline & O1 & $\mathrm{O} 2$ & $\mathrm{O} 3$ \\
\hline $\begin{array}{l}\text { Dos processos arbitrais deste órgão, as empresas construtoras } \\
\text { correspondem a qual proporção sobre os casos totais? }\end{array}$ & $40 \%$ & $10 \%$ & $30 \%$ \\
\hline $\begin{array}{c}\text { Dos processos arbitrais que envolvem empresas construtoras, qual a } \\
\text { proporção de utilização de cláusula compromissória, e qual a } \\
\text { proporção de uso de compromisso arbitral? }\end{array}$ & $\begin{array}{l}\text { Praticamente só } \\
\text { cláusula } \\
\text { compromissória; } \\
\text { compromisso } \\
\text { arbitral } 1 \%\end{array}$ & $\begin{array}{l}\text { Só cláusula } \\
\text { compromissória }\end{array}$ & $\begin{array}{l}\text { Só cláusula } \\
\text { compromissória }\end{array}$ \\
\hline $\begin{array}{c}\text { Dos contratos com cláusulas compromissórias, proporcionalmente, } \\
\text { quantos se referem a contratos privados? E a PPP? }\end{array}$ & Todos privados & Todos privados & Todos privados \\
\hline $\begin{array}{l}\text { Dos contratos com compromisso arbitral, proporcionalmente, } \\
\text { quantos se referem a contratos privados? E a PPP? }\end{array}$ & Não aplicável & Não aplicável & Não aplicável \\
\hline $\begin{array}{l}\text { Há algum setor onde o emprego do mecanismo é mais significativo } \\
\text { (Infraestrutura, Edificações)? }\end{array}$ & $\begin{array}{l}\text { Infraestrutura e } \\
\text { pequenas centrais } \\
\text { hidrelétricas }\end{array}$ & Edificações & Equilibrado \\
\hline $\begin{array}{l}\text { Qual o volume de casos em que as partes envolvidas na arbitragem são } \\
\text { construtoras e agentes contratados (por exemplo, subempreiteiros, } \\
\text { fornecedores, etc.)? }\end{array}$ & Nenhum & $\begin{array}{c}\text { Metade } \\
\text { construtora/cliente } \\
\text { e metade } \\
\text { construtora/subem } \\
\text { preiteiro }\end{array}$ & $\begin{array}{l}10 \% \\
\text { corresponde a } \\
\text { construtora/ } \\
\text { subcontratado }\end{array}$ \\
\hline $\begin{array}{l}\text { Existem casos de arbitragem entre construtoras/incorporadoras e } \\
\text { adquirentes de frações ideais? Qual o volume sobre o total de casos de } \\
\text { empresas construtoras? }\end{array}$ & $\begin{array}{l}\text { Não, o custo não } \\
\text { compensa }\end{array}$ & $\begin{array}{c}\text { Somente um caso, } \\
\text { o código do } \\
\text { consumidor é mais } \\
\text { utilizado }\end{array}$ & $\begin{array}{l}\text { Não, o código do } \\
\text { consumidor } \\
\text { desestimula. }\end{array}$ \\
\hline $\begin{array}{l}\text { Quais as razões pelas quais as empresas construtoras utilizam a } \\
\text { arbitragem? }\end{array}$ & $\begin{array}{l}\text { Sigilo, rapidez, } \\
\text { qualidade da } \\
\text { decisão }\end{array}$ & $\begin{array}{l}\text { Raídez, eficácia e } \\
\text { especialidade }\end{array}$ & $\begin{array}{l}\text { Rapidez, } \\
\text { agilidade, sigilo }\end{array}$ \\
\hline O que explica sua não utilização? & $\begin{array}{c}\text { Falta de interesse } \\
\text { na resolução, } \\
\text { interessa } \\
\text { postergar para } \\
\text { pagar menos }\end{array}$ & $\begin{array}{l}\text { Desconhecimento, } \\
\text { custo elevado }\end{array}$ & $\begin{array}{c}\text { Empresas: } \\
\text { desconhecimento, } \\
\text { insegurança, } \\
\text { postergação; } \\
\text { Advogados: } \\
\text { preconceito, } \\
\text { desconhecimento } \\
\text { ou estratégia de } \\
\text { defesa }\end{array}$ \\
\hline
\end{tabular}

(continua) 


\begin{tabular}{|c|c|c|c|}
\hline \multirow{2}{*}{ Questão } & \multicolumn{3}{|c|}{ Órgãos arbitrais institucionais } \\
\hline & 01 & $\mathrm{O} 2$ & $\mathrm{O} 3$ \\
\hline Quais as desvantagens as construtoras apontam? & $\begin{array}{l}\text { Processo deveria } \\
\text { ser mais rápido }\end{array}$ & Não apontaram & Preço \\
\hline Como tais empresas avaliam os resultados obtidos? & Satisfeitas & Favoravelmente & $\begin{array}{l}\text { Bom, pela } \\
\text { finalização do } \\
\text { conflito }\end{array}$ \\
\hline $\begin{array}{l}\text { Quais os agentes que empregam com maior freqüência as arbitragens } \\
\text { (incorporador, construtora, subcontratado, agente financeiro, etc.)? }\end{array}$ & $\begin{array}{l}\text { Contratante e } \\
\text { construtora }\end{array}$ & Todos & $\begin{array}{c}\text { Em infraestrutura } \\
\text { são as } \\
\text { construtoras e } \\
\text { subcontratados; } \\
\text { em edificações } \\
\text { são as financeiras } \\
\text { e incorporadoras }\end{array}$ \\
\hline $\begin{array}{c}\text { Contratos administrativos com arbitragem - já houve tentativa de } \\
\text { utilização? }\end{array}$ & Não & Não & Não \\
\hline E empresas públicas ou mistas já tentaram se valer da arbitragem? & Não & Não & Não \\
\hline $\begin{array}{l}\text { O prazo constante da Lei } 9307 / 96 \text {, de } 180 \text { dias, é cumprido ou as partes } \\
\text { elegem novos prazos? }\end{array}$ & Não & $\begin{array}{l}\text { Não; a média é de } \\
1 \text { ano }\end{array}$ & Sim \\
\hline $\begin{array}{l}\text { Quais melhorias este órgão sugere para o processo arbitral, em relação } \\
\qquad \text { à lei } 9307 / 96 ?\end{array}$ & $\begin{array}{c}\text { A lei é ótima, não } \\
\text { há necessidade } \\
\text { de mudanças }\end{array}$ & $\begin{array}{l}\text { Falta glossário de } \\
\text { têrmos. }\end{array}$ & $\begin{array}{c}\text { A lei é } \\
\text { transparente e } \\
\text { perfeita }\end{array}$ \\
\hline Quais ações este órgão sugere para incrementar o uso da arbitragem? & $\begin{array}{l}\text { Câmaras arbitrais } \\
\text { com valores mais } \\
\text { baixos; maior } \\
\text { conhecimento do } \\
\text { mecanismo por } \\
\text { conta dos agentes }\end{array}$ & $\begin{array}{c}\text { Divulgação, } \\
\text { palestras e cursos }\end{array}$ & $\begin{array}{l}\text { Divulgação junto a } \\
\text { construtoras e } \\
\text { advogados }\end{array}$ \\
\hline Houve um incremento na quantidade de uso de arbitragem neste órgão? & $\begin{array}{c}\text { Sim, em especial } \\
\text { nos últimos dois } \\
\text { anos }\end{array}$ & Sim & $\begin{array}{c}\text { Sim, em especial } \\
\text { nos últimos dois } \\
\text { anos }\end{array}$ \\
\hline
\end{tabular}

Tabela 2 - Transcrição das entrevistas com os órgãos arbitrais institucionais.

\subsection{Análise da pesquisa efetuada em empresas construtoras}

As entrevistas lastreadas em questionários estruturados foram efetuadas em três empresas construtoras de grande porte, com atuação em obras privadas e públicas. No APENDICE 2 estão as transcrições das perguntas e respostas das entrevistas em cada empresa construtora, que foram nomeadas pelas letras C1, C2 e C3 de maneira aleatória.

Os resultados das entrevistas indicam:

- Os motivos principais que levam as empresas construtoras a se utilizarem da arbitragem são a rapidez, a qualidade da sentença conseqüência do julgamento técnico promovido pelo árbitro no 
processo - e a segurança que estes fatores proporcionam. Há também a postura de agentes financeiros que exigem a cláusula compromissória nos contratos das obras por estes financiadas.

- Por outro lado, o alto custo das arbitragens desmotiva o seu uso. Este alto custo deriva do fato das empresas construtoras utilizarem apenas órgãos institucionais de grande porte, com custos administrativos altos e cujos árbitros também recebem honorários altos, em função da sua expertise e renome. Some-se a isto outro fator, que tais empresas sempre preferem cortes arbitrais com no mínimo três árbitros, aumentando ainda mais o custo final. Isto limita a utilização da arbitragem a contratos de alto valor, comprovado pelo fato da empresa construtora $\mathrm{C} 1$ se valer de seu uso em contratos apenas com valores maiores que US $\$ 11,50$ milhões, na data base de dezembro de 2009.

- As empresas construtoras utilizam atualmente a arbitragem apenas em contratos privados, mas no passado já houve inserção da cláusula compromissória em contratos de PPP pela empresa construtora C3. No caso de contratos administrativos com empresas públicas ou mistas, há a possibilidade de uso, desde que conste no edital de concorrência a sua exigência, ou quando há financiamento externo da obra, em que a arbitragem é praticamente compulsória, segundo a empresa construtora C3.

- Somente se utilizou a arbitragem com a inclusão de cláusula compromissória, não havendo nenhum caso de uso de compromisso arbitral.

- As empresas construtoras também se valem da arbitragem para solução de disputas com agentes subcontratados, mas restrito a contratos de valores expressivos, em função do custo da arbitragem.

- O sub-setor de infraestrutura sobressai em relação ao de edificações na utilização da arbitragem. A empresa construtora C3 declarou 
utilizá-la mais em edificações, porém com a justificativa de que as obras de infraestrutura em execução eram exclusivamente públicas, que não admitiam a arbitragem em seus contratos.

- As vantagens citadas são a rapidez, eficiência, qualidade da sentença e segurança.

- Já as desvantagens nomeadas são o custo e uma insegurança causada pelo fato da sentença arbitral ser irrecorrível, ou seja, no caso do árbitro decretar uma sentença de má qualidade não há maneira de alterá-la. Isto reforça a posição das empresas construtoras apenas se utilizarem de órgãos arbitrais institucionais, pois há possibilidade da disputa ser julgada com mais qualidade, mas que, porém, acaba incorrendo em maior custo, e limitando os contratos passíveis de serem arbitrados àqueles de valor alto. Um dado levantado pela empresa construtora C3 é sobre a alta freqüência da utilização dos mesmos árbitros de renome, levando-os a ficarem impedidos de julgarem diversas causas, pois há uma alternância da empresas em ser réu ou autor de ações simultâneas onde o árbitro é o mesmo. A conseqüência, pela falta de variação na escolha dos árbitros, é a sua escassez, havendo a necessidade da entrada de novos árbitros para suprir esta carência.

- As empresas construtoras consideram os resultados obtidos nas cortes arbitrais satisfatórios, pela eficiência, rapidez, e pelas decisões técnicas e bem fundamentadas.

- Os contratos mais utilizados são os de empreitada, preponderando o contrato EPC.

- As maiores causas de conflitos são as falhas em projetos, as inadimplências contratuais em geral (não cumprimento de prazo, falta de licenças ambientais, falta de pagamento, entre outros), problemas geológicos e climáticos. 
- O prazo estipulado em lei de 180 dias em geral não é cumprido, sendo o prazo máximo de dois anos para término do julgamento.

- As empresas construtoras julgam boa a lei 9306/97. Nota-se, porém, que há um temor, conforme já citado, pelo fato da sentença ser irrecorrível, havendo um anseio das mesmas no uso da jurisprudência, que significa o aproveitamento daquilo que serve como modelo, referindo-se a sentenças já proferidas em casos semelhantes.

$\mathrm{Na}$ tabela 3 estão transcritas as entrevistas com as empresas construtoras.

\begin{tabular}{|c|c|c|c|}
\hline \multirow{2}{*}{ Questão } & \multicolumn{3}{|c|}{ Construtoras } \\
\hline & C1 & $\mathrm{C} 2$ & C3 \\
\hline $\begin{array}{l}\text { Quais as razões pelas quais a empresas construtora inclui em seus } \\
\text { contratos a cláusula compromissória? }\end{array}$ & $\begin{array}{l}\text { Tempo, expertise } \\
\text { do árbitro, } \\
\text { segurança }\end{array}$ & $\begin{array}{l}\text { Segurança, } \\
\text { rapidez, por chegar } \\
\text { a um resultado }\end{array}$ & $\begin{array}{l}\text { Exigência por } \\
\text { causa dos } \\
\text { financiamentos } \\
\text { externos, } \\
\text { celeridade e } \\
\text { julgamento técnico }\end{array}$ \\
\hline $\begin{array}{l}\text { Quais as razões que explicam a não utilização da cláusula } \\
\text { compromissória em seus contratos? }\end{array}$ & $\begin{array}{l}\text { Custo para } \\
\text { contratos de valor } \\
\text { baixo }\end{array}$ & É caro & $\begin{array}{l}\text { Em contratos de } \\
\text { obras públicas } \\
\text { falta de } \\
\text { conhecimento; é } \\
\text { caro }\end{array}$ \\
\hline $\begin{array}{l}\text { Qual o volume de sua inclusão para cada tipo de obra em contratos } \\
\text { privados e de PPP? }\end{array}$ & Só privado & Só privado & Só privado \\
\hline $\begin{array}{l}\text { Quais as razões pelas quais, quando não utilizam a cláusula, fazem uso } \\
\text { do compromisso arbitral em uma disputa? }\end{array}$ & $\begin{array}{l}\text { Não utilizam } \\
\text { compromisso } \\
\text { arbitral }\end{array}$ & $\begin{array}{l}\text { Não utilizam } \\
\text { compromisso } \\
\quad \text { arbitral }\end{array}$ & $\begin{array}{l}\text { Não utilizam } \\
\text { compromisso } \\
\text { arbitral }\end{array}$ \\
\hline Em que proporção isso ocorre e para que tipos de obras? & Não ocorreu & Não ocorreu & Não ocorreu \\
\hline $\begin{array}{l}\text { Utiliza a cláusula também com os agentes contratados? Com quais e } \\
\text { em que percentuais? }\end{array}$ & Subeempreiteiro & Não & $\begin{array}{l}\text { Muito pouco, em } \\
\text { contratos de valor } \\
\text { alto com } \\
\text { subempreiteiros }\end{array}$ \\
\hline Quais segmentos de obras mais a utilizam? & Infra-estrutura & Infra-estrutura & $\begin{array}{l}\text { Edificaçốes } \\
\text { privadas }\end{array}$ \\
\hline $\begin{array}{l}\text { É incorporador? Caso seja, costuma utilizar a cláusula em contratos de } \\
\text { venda de frações ideais? }\end{array}$ & Não é incorporador & $\begin{array}{c}\text { Não é } \\
\text { incorporador }\end{array}$ & Não usa \\
\hline Qual o tipo de contrato utilizado, empreitada global, EPC, aliança, FIDIC? & $\begin{array}{l}\text { Todos, com EPC } \\
\text { sempre usamos a } \\
\text { arbitragem }\end{array}$ & EPC & $\begin{array}{l}\text { Empreitadas a } \\
\text { preços unitários }\end{array}$ \\
\hline $\begin{array}{l}\text { Em contratos administrativos com empresas publicas ou mistas a } \\
\text { construtora já assinou contrato com cláusula compromissória? }\end{array}$ & Não & $\begin{array}{l}\text { Sim, quando há } \\
\text { financiamento } \\
\text { externo }\end{array}$ & $\begin{array}{l}\text { Com empresa } \\
\text { mista, quando } \\
\text { consta em edital }\end{array}$ \\
\hline Que vantagens percebe na utilização da arbitragem? & $\begin{array}{l}\text { Rapideze } \\
\text { eficiência }\end{array}$ & $\begin{array}{l}\text { Velocidade e } \\
\text { segurança }\end{array}$ & $\begin{array}{l}\text { Celeridade e } \\
\text { árbitros técnicos }\end{array}$ \\
\hline
\end{tabular}

(continua) 
(conclusão)

\begin{tabular}{|c|c|c|c|}
\hline \multirow{2}{*}{ Questão } & \multicolumn{3}{|c|}{ Construtoras } \\
\hline & C1 & $\mathrm{C} 2$ & C3 \\
\hline E quais são as desvantagens? & $\begin{array}{l}\text { Insegurança } \\
\text { causada pelos } \\
\text { árbitros em } \\
\text { relação ao } \\
\text { resultado da } \\
\text { demanda;falta de } \\
\text { jurisprudência. }\end{array}$ & Custo & $\begin{array}{l}\text { É caro e faltam } \\
\text { árbitros de renome }\end{array}$ \\
\hline Como avaliam os resultados obtidos? & $\begin{array}{c}\text { Eficiente, decisões } \\
\text { bem } \\
\text { fundamentadas }\end{array}$ & $\begin{array}{l}\text { Satisfatório, pelo } \\
\text { resultado ser } \\
\text { técnico }\end{array}$ & Bom pela rapidez \\
\hline Quais melhorias sugerem para o processo? & $\begin{array}{c}\text { A lei é boa, porém } \\
\text { falta a } \\
\text { jurisprudência }\end{array}$ & $\begin{array}{c}\text { A lei é boa, porém } \\
\text { executar a } \\
\text { sentença no } \\
\text { judiciário é } \\
\text { problemático caso } \\
\text { seja necessário }\end{array}$ & $\begin{array}{c}\text { A lei é boa, porém } \\
\text { falta a } \\
\text { jurisprudência }\end{array}$ \\
\hline Quais os motivos dos conflitos? & $\begin{array}{l}\text { Projetos com } \\
\text { erros, omissões, } \\
\text { problemas } \\
\text { geológicos. }\end{array}$ & $\begin{array}{c}\text { Falhas e } \\
\text { modificações em } \\
\text { projetos, } \\
\text { contratante não } \\
\text { cumpre } \\
\text { obrigações, } \\
\text { problemas } \\
\text { climáticos }\end{array}$ & $\begin{array}{l}\text { Inadimplementos, } \\
\text { prazo, falta de } \\
\text { verba, problemas } \\
\text { geológicos }\end{array}$ \\
\hline Utiliza arbitragem Institucional ou ad hoc? & Institucional & Institucional & Institucional \\
\hline Quantos árbitros são escolhidos? & Um ou três & Três & Três \\
\hline O prazo é seguido? & $\begin{array}{c}\text { Não, dura até dois } \\
\text { anos }\end{array}$ & Não, até 14 meses & Sim \\
\hline Já utilizou Dispute Review Boards ou Dispute Adjucation Board? & Não & Não & Sim, DRB \\
\hline
\end{tabular}

Tabela 3 - Transcrição das entrevistas com as empresas construtoras.

\subsection{Análise da pesquisa efetuada em escritório de advocacia}

As entrevistas lastreadas em questionários estruturados foram efetuadas em três escritórios de advocacia de grande porte e renome, que assessoram empresas de construção civil em obras privadas e públicas. No APENDICE 3 estão as transcrições das perguntas e respostas das entrevistas em cada escritórios, que foram nomeados pelas letras E1, E2 e E3 de maneira aleatória.

Os resultados das entrevistas indicam: 
- O volume dos conflitos assessorados por advogados que são levados a tribunais arbitrais variam de escritório a escritório, de um quinto a metade dos casos totais, sendo significativos em função do amplo espectro de ações que estes escritórios atendem.

- Todas as arbitragens em contratos de construção civil nas quais estes escritórios estão envolvidos referem-se a contratos privados, e nenhuma delas estão vinculadas a contratos para execução de obras de PPP.

- Novamente as arbitragens aconteceram baseadas apenas na utilização da cláusula compromissória, não havendo nenhum caso de uso de compromisso arbitral.

- As principais vantagens citadas da utilização da arbitragem são o custo, o sigilo, a celeridade, o julgamento técnico promovido pelo árbitro no processo, a participação ativa do árbitro no processo arbitral e o custo-benefício.

- Citam como desvantagens o alto custo para determinados valores contratuais, a impossibilidade de recorrer da sentença no caso do desfecho não ser favorável ao seu cliente, as decisões equivocadas proferidas pelo árbitro que são contrárias ao direito (que, no entanto podem ser anuladas pela anulação da sentença arbitral), o árbitro que age fora de suas funções, tentando agir como mediador em vez de árbitro e as decisões tecnicamente incorretas.

- A inserção da cláusula compromissória é praticamente total nos contratos das empresas construtoras que os escritórios E1 e E2 assessoram; o escritório E3 declara ser baixa a sua utilização nos contratos que elabora.

- Os agentes que mais utilizam a arbitragem são as empresas construtoras, e também as incorporadoras. 
- Há um equilíbrio nos setores que utilizam a arbitragem, pois foram citadas as edificações, as obras de infraestrutura e também as grandes incorporações. Em comum, observa-se o valor alto dos contratos. Em relação aos adquirentes de frações ideais, em se tratando de incorporações, dois escritórios, E1 e E3, citaram que não se utilizam da arbitragem, pois a lei de incorporações seria mais eficiente para solucionar as disputas, no caso de rescisão contratual; já o escritório E2 a utiliza. Notou-se que o uso da arbitragem neste caso facilita de modo indireto $o$ entendimento entra a construtora/incorporadora e o adquirente da fração ideal, pois seu alto custo inibe o litígio, sendo mais vantajoso às partes chegarem a um acordo.

- Os escritórios de advocacia informaram não terem inserido a cláusula compromissória em contratos administrativos, com exceção de um único caso, onde uma das partes era uma empresa mista, conforme informado pelo escritório E3.

- Os contratos mais utilizados são os de empreitada global, seguidos de contratos específicos elaborados pelos próprios escritórios.

- Os escritórios de advocacia consideram que as empresas construtoras estão satisfeitas com os resultados obtidos nas cortes arbitrais, e em geral cumprem as sentenças, mesmo as desfavoráveis.

- Citam que as causas de conflitos mais comuns são os planejamentos falhos das obras, as alterações das condições financeiras no decorrer da obra, os problemas financeiros de uma das partes, os vícios construtivos decorrentes da má-execução, os problemas climáticos e a reivindicação de pagamento de serviços extracontratuais.

- A lei 9306/97 é considerada eficiente, com a ressalva do escritório E2 de não se utilizar a jurisprudência na sentença arbitral. 
- A arbitragem utilizada é sempre institucional e o prazo estipulado em lei de 180 dias não é cumprido, variando de doze a quatorze meses.

$\mathrm{Na}$ tabela 4 estão transcritas as entrevistas com os escritórios de advocacia.

\begin{tabular}{|c|c|c|c|}
\hline \multirow{2}{*}{ Questão } & \multicolumn{3}{|c|}{ Escritórios de Advocacia } \\
\hline & E1 & E2 & E3 \\
\hline $\begin{array}{l}\text { Dos casos levados a tribunais arbitrais qual o volume destes se } \\
\text { refere a empresas construtoras? }\end{array}$ & Um terço & Metade & $20 \%$ \\
\hline Quantas arbitragens referiam-se a obras privadas? & Todas & Todas & Todas \\
\hline Quantas arbitragens referiam-se a obras de PPP? & Nenhuma & Nenhuma & Nenhuma \\
\hline Que vantagens percebe na utilização da arbitragem? & $\begin{array}{l}\text { Custo, sigilo e } \\
\text { rapidez }\end{array}$ & $\begin{array}{c}\text { Rapidez, } \\
\text { julgamento } \\
\text { técnico, } \\
\text { participação ativa } \\
\text { do árbitro }\end{array}$ & $\begin{array}{l}\text { Celeridade, sigilo, } \\
\text { custo-beneficio, } \\
\text { qualidade da } \\
\text { decisão }\end{array}$ \\
\hline E quais as desvantagens? & $\begin{array}{l}\text { Não há } \\
\text { possibilidade de } \\
\text { recorrer }\end{array}$ & $\begin{array}{c}\text { Decisões } \\
\text { contrárias ao } \\
\text { direito, árbitro age } \\
\text { fora das funções, } \\
\text { custo alto, } \\
\text { decisões não } \\
\text { técnicas }\end{array}$ & Custo Financeiro \\
\hline $\begin{array}{l}\text { Qual a freqüência de inclusão de cláusula compromissória nos } \\
\text { contratos que realiza para seus clientes construtoras? }\end{array}$ & Quase $100 \%$ & Em todos & Baixa \\
\hline Há algum agente que emprega com maior freqüência a arbitragem? & Construtoras & Construtoras & $\begin{array}{l}\text { Incorporadoras e } \\
\text { construtoras }\end{array}$ \\
\hline $\begin{array}{l}\text { Há algum setor onde o emprego do mecanismo é mais significativo } \\
\text { (Infraestrutura, Edificações)? }\end{array}$ & Edificações & $\begin{array}{l}\text { Infraestrutura e } \\
\text { grandes } \\
\text { incorporações }\end{array}$ & Infraestrutura \\
\hline $\begin{array}{l}\text { Incorporações a utilizam para solucionar disputas com adquirentes } \\
\text { das fraços ideais? }\end{array}$ & Não & Sim & Não \\
\hline $\begin{array}{l}\text { Qual o tipo de contrato utilizado, empreitada global, EPC, aliança, } \\
\text { FIDIC? }\end{array}$ & Contratos próprios & $\begin{array}{l}\text { Empreitada } \\
\text { Global }\end{array}$ & $\begin{array}{l}\text { Empreitada } \\
\text { Global }\end{array}$ \\
\hline Já se utilizou de arbitragem em contratos administrativos? & Nunca & Não & $\begin{array}{l}\text { Um caso, de } \\
\text { empresa mista }\end{array}$ \\
\hline Como as empresas avaliam os resultados obtidos? & $\begin{array}{l}\text { Cumprem as } \\
\text { sentenças }\end{array}$ & Satisfeitas & Bom \\
\hline Quais melhorias sugerem para o processo? & $\begin{array}{l}\text { Não vejo } \\
\text { necessidade }\end{array}$ & Jurisprudência & $\begin{array}{l}\text { Tornar o ambiente } \\
\text { mais propício à } \\
\text { utilização da } \\
\text { arbitragem }\end{array}$ \\
\hline Quais os motivos dos conflitos? & $\begin{array}{l}\text { Planejamentos de } \\
\text { obras falhos, } \\
\text { alteração das } \\
\text { condições } \\
\text { financeiras, } \\
\text { problemas } \\
\text { climáticos }\end{array}$ & $\begin{array}{c}\text { Vícios } \\
\text { construtivos em } \\
\text { vistorias } \\
\text { intermediárias e } \\
\text { no recebimento } \\
\text { da obra }\end{array}$ & $\begin{array}{l}\text { Problemas em } \\
\text { projetos, } \\
\text { deficiências em } \\
\text { planejamento e } \\
\text { gestão de obra } \\
\text { falho, falta de } \\
\text { dinheiro, serviços } \\
\text { extras sempre, } \\
\text { modificações de } \\
\text { projetos, } \\
\text { problemas } \\
\text { climáticos }\end{array}$ \\
\hline Utiliza arbitragem Institucional ou ad hoc? & Institucional & Institucional & Institucional \\
\hline Quantos árbitros são escolhidos? & Sempre três & Três ou cinco & Três \\
\hline O prazo estipulado na lei ( 180 dias) é seguido? & $\begin{array}{l}\text { Em geral é } \\
\text { prorrogado }\end{array}$ & $\begin{array}{l}\text { Não, média de } \\
\text { um ano }\end{array}$ & $\begin{array}{l}\text { Nunca, média de } \\
14 \text { meses }\end{array}$ \\
\hline
\end{tabular}

Tabela 4 - Transcrição das entrevistas com os escritórios de advocacia 


\subsection{Resultado integrado das entrevistas}

Após a coleta dos dados pelas entrevistas com os órgãos institucionais arbitrais, as empresas construtoras e os escritórios de advocacia, e sua análise parcial, procurou-se integrar todas as informações em uma única análise para delimitação do panorama da utilização da arbitragem, suas vantagens e desvantagens. Dentro da análise qualitativa proposta pela metodologia da pesquisa, notou-se que as os resultados encontrados nos três segmentos entrevistados são convergentes.

Quanto à utilização da arbitragem, há uma tendência crescente tanto por parte das empresas construtoras, como também dos escritórios de advocacia. Isto é corroborado pelas informações fornecidas pelos órgãos institucionais arbitrais nacionais aonde o volume de casos vem crescendo, em especial nos últimos dois anos e confirmando as informações de Grion (2007) citadas no capítulo 3.1 desta pesquisa. O órgão institucional arbitral O1 é o único que fornece estatísticas de sua câmara de arbitragem, e é significativa a informação que em 30 anos há um histórico de 164 casos de arbitragens, sendo que 44 casos ocorreram em 2009, indicando um aumento de casos.

Em relação a qual instrumento é mais utilizado para a instituição da arbitragem, verificou-se que o compromisso arbitral não é usado, ou seja, a arbitragem é sempre decidida pela cláusula compromissória. Confirma-se uma tendência de que, se não há uma pré-disposição dos agentes para se solucionar as disputas pela arbitragem ao se elaborar o contrato da obra, não o haverá após o surgimento do conflito.

A arbitragem é utilizada quase que exclusivamente em disputas ligadas a obras privadas. Embora a legislação brasileira permita seu uso em contratos de obras de PPP, não foi relatado nenhum caso. Em contratos administrativos que envolvam empresas mistas ou estatais existe essa possibilidade, sendo possível citar dois fatores que a estimulam, a exigência 
por parte de agentes que financiam as obras, e editais de concorrência das obras que exigem a inserção da cláusula compromissória, mas o seu uso ainda é muito baixo. Saliente-se que em todas as entrevistas foi citado um único caso de arbitragem que envolvia um contrato administrativo, por parte de um dos escritórios de advocacia.

Quanto à predominância de algum sub-setor que mais utilize a arbitragem, a pesquisa demonstrou um equilíbrio entre os sub-setores de infraestrutura e edificações, em número de arbitragens. Já em relação a valores dos contratos arbitrados, embora estes não fossem revelados em função do sigilo, verificou-se nas entrevistas que 0 sub-setor de infraestrutura corresponde aos maiores valores. Foi significativa a informação de uma empresa construtora de que seus contratos com cláusula compromissória correspondem a $20 \%$ do total das obras, porém em valores monetários correspondem a $60 \%$ do faturamento da empresa, e são em sua maioria contratos de obras de infraestrutura.

Quanto aos agentes que participam das disputas arbitradas, predominam empresa construtora e cliente, ocorrendo também entre empresa construtora e agentes subcontratados, neste caso limitado pelo valor dos contratos, onde contratos de baixos valores não contêm a cláusula compromissória. Uma das alternativas de uso da arbitragem, entre incorporadora e adquirentes de frações idéias, não se configurou viável, em função dos altos valores de uma arbitragem frente aos valores de venda dos imóveis, e também em função da legislação. O código do consumidor e a lei das incorporações são citadas pelos advogados como alternativas mais viáveis para a solução de um conflito ou uma rescisão contratual, nestes casos.

Quanto às vantagens da arbitragem, alguns fatores são sempre nomeados, em especial, a celeridade do processo arbitral (embora o prazo legal de 180 dias seja sempre prorrogado, em geral o processo encerra-se entre seis meses e dois anos, lembrando que na justiça estatal os prazos são dilatados, gerando a sensação dos processos serem intermináveis), o sigilo, a qualidade da sentença (técnica e bem fundamentada), a participação ativa 
do árbitro no processo arbitral e a certeza de solução da disputa. A qualidade da sentença está ligada à especialidade e à capacidade dos árbitros, lembrando que estes são escolhidos pelas partes, que procurarão indicar aqueles com notório saber no assunto arbitrado. Citou-se também o custo-benefício da arbitragem, pois paradoxalmente, embora o custo foi citado como desvantagem, há o sentimento de que o processo arbitral é rápido, e que caso fosse utilizada a justiça estatal as perdas futuras poderiam ser maiores, em função de lucros cessantes, abalos na imagem, e outras ações paralelas na justiça decorrentes do mesmo conflito. Deve-se levar em conta não apenas os custos processuais, mas outros custos decorrentes da disputa.

Quanto às desvantagens, não se configurou a expectativa de que a arbitragem tivesse um custo baixo, conforme informado por diversos autores. Ocorre que empresas construtoras e escritórios de advocacia não confiam em arbitragens que não sejam conduzidas por órgãos arbitrais institucionais de grande porte, as quais contam com árbitros caros e cobram taxas para administrar o andamento dos processos arbitrais. Afastam, deste modo, as arbitragens ad hoc, que poderiam ser conduzidas por um único árbitro, com valores menores. Os processos enviados a estes árbitros poderiam ser de contratos de valores baixos, mas isto não ocorre, pois há uma concentração de contratos de valores altos em órgãos arbitrais institucionais, gerando uma delimitação do mercado alcançado pela arbitragem.

Outra desvantagem informada é a insegurança causada pelo fato certo da sentença arbitral ser irrecorrível, e também de ser título executivo. Caso o árbitro decrete uma sentença de má qualidade ou incorreta, não há como alterá-la, exceto por anulação da sentença. Uma sentença arbitral só pode ser anulada dentro das condições do artigo 32 da lei 9307/96, havendo erro processual, ou por vício dos árbitros, tais como prevaricação, parcialidade, falta de neutralidade e outras condições que indiquem a falta de honestidade no processo. Esta situação acaba também reforçando a posição de utilização de órgãos arbitrais institucionais com árbitros múltiplos, mais 
caros. Como a sentença é irrecorrível, vários entrevistados citaram como desvantagem o impedimento de uso da jurisprudência, aproveitando como modelo para a sentença arbitral outras sentenças já proferidas em casos semelhantes.

Em relação à formação dos tribunais arbitrais, nas entrevistas com os órgãos arbitrais institucionais e construtoras foi apontada como composição ideal de um tribunal arbitral em contratos de construção civil a nomeação de um tribunal misto, composto de advogado, engenheiro e perito contábil. Esta composição agrega o conhecimento jurídico para os procedimentos processuais, o conhecimento técnico da engenharia e o conhecimento legal e financeiro para a execução de cálculos monetários complexos.

Levando-se em conta as vantagens e desvantagens da arbitragem, as empresas construtoras são favoráveis ao seu uso, pela solução rápida, pela eficiência, e pelas decisões técnicas e bem fundamentadas.

Quanto aos contratos mais utilizados, o mais citado é de empreitada, em geral EPC, e contratos elaborados especificamente para cada obra individualmente pelos escritórios de advocacia.

Quanto às causas dos conflitos e disputas, as mais citadas foram as falhas em projetos e suas alterações no decorrer da obra, as falhas em planejamento e gestão das obras, as alterações financeiras durante a execução da obra, as inadimplências contratuais (tais como não cumprimento de prazo, falta de licenças ambientais e falta de pagamento, dentre outros), os problemas geológicos e climáticos, os problemas financeiros de uma das partes, os vícios construtivos decorrentes da máexecução e a reivindicação de pagamento de serviços extracontratuais.

Em resumo, a arbitragem é majoritariamente utilizada em contratos privados, instituída pela cláusula compromissória em contratos de valores altos, solucionando disputas principalmente entre clientes e empresas construtoras. Os agentes consideram-na satisfatória, atingindo os objetivos pretendidos, pelo fato de ser rápida, sigilosa e com sentenças de boa 
qualidade técnica. É considerada uma solução cara, por serem utilizados órgãos arbitrais institucionais de grande porte e pela falta de confiança dos agentes em instituições arbitrais de pequeno porte ou em arbitragens ad hoc. Os contratos mais utilizados são os de empreitada e as maiores causas de conflito são as falhas e alterações de projetos, as inadimplências contratuais, as falhas de gestão e planejamento das obras, os problemas climáticos e geológicos e os problemas financeiros.

\section{CAPÍTULO 5}

Neste capítulo são apresentadas as proposições desta pesquisa, com sugestões para o incremento da utilização da arbitragem nos contrato de construção civil.

\section{Proposições}

Deve-se inicialmente considerar que, pela complexidade de informações de uma obra contidas em projetos e métodos construtivos, sistemas de planejamento e gestão, qualidade de execução e outras variáveis existentes, torna-se muito difícil prever em um contrato todos os riscos potenciais que possam levar a disputas, e que foi comprovado pela pesquisa. Nesta, verificou-se que além da complexidade interna ao próprio projeto e contrato, existem os fatores externos que contribuem para os litígios, os quais são imprevisíveis e fogem do controle dos agentes. Destes, pode-se citar os problemas geológicos e climáticos, alterações das condições financeiras do país e do mercado. Portanto, conflitos e disputas estão latentes no contexto de uma obra de construção civil, com o risco de surgirem no decorrer de sua execução, por fatores internos ou externos, mesmo o contrato tendo sido minucioso e procurado cobrir todos os riscos possíveis. Havendo a disputa, os agentes podem escolher a justiça estatal ou a arbitragem para resolvê-la. 
Seguida a metodologia escolhida da pesquisa, e após a análise das informações coletadas em órgãos arbitrais institucionais, empresas construtoras e escritórios de advocacia, foi possível montar o panorama da utilização da arbitragem em contratos de construção civil.

Sob a ótica da empresa construtora, a lei da arbitragem confere uma situação de conforto e segurança em função da definição rápida das disputas, com qualidade técnica das sentenças e sigilo processual. Portanto algumas proposições podem ser feitas para disseminar sua maior utilização.

Este panorama demonstra que há um crescimento do número de arbitragens nos últimos anos, e também um ambiente favorável entre os agentes para sua utilização. Porém, só utilizará a arbitragem quem dela tiver conhecimento, caso da empresas construtoras pesquisadas, com especialidade em execução de obras privadas e PPP, que no caso são empresas de grande porte. Nas entrevistas com os órgãos arbitrais institucionais percebeu-se que as empresas de menor porte não fazem uso da arbitragem, em função do desconhecimento do mecanismo da lei 9307/96 por parte delas ou de seus advogados, e uma cultura de postergar a decisão do processo, caso este esteja em condições que não lhes sejam favoráveis. Uma das proposições desta pesquisa, portanto, seria a de difusão da lei 9307/96 e dos benefícios de seu uso junto a empresas médias ou de pequeno porte e advogados destas empresas.

Conforme apontado pela pesquisa, existem raríssimas utilizações da arbitragem em contratos administrativos e PPP, em geral ligados a exigência de organismo financiador estrangeiro, exigência esta previamente inserida no edital de concorrência com empresas mistas, não havendo nenhum caso detectado na pesquisa de empresas públicas. Uma informação fornecida por um dos advogados entrevistados é a de que se nota insegurança no poder público, devido à rapidez do julgamento, impossibilidade de recorrer da sentença, e desconhecimento dos mecanismos do processo arbitral. Por outro lado, um dos escritórios de advocacia que já participou de uma arbitragem envolvendo uma empresa mista declarou que "as empresas 
mistas e estatais procuram através de seus administradores a excelência em administração, e não se oporiam em utilizar a arbitragem". Propõe-se, por conseguinte, maior difusão da lei da arbitragem dentro das empresas mistas, pois, dependendo do tipo de serviço prestado, nas mesmas condições que no setor privado, contratando como se fosse empresa privada, dispondo sobre direitos patrimoniais com particulares e não dependendo da lei 8666/1993, existirão condições para o uso da arbitragem. No caso das empresas públicas, não existe consenso jurídico se a arbitragem pode ser utilizada. Portanto, não se aconselha sua utilização até que haja a convicção legal.

O levantamento e revisão bibliográfica mostravam que uma das vantagens da arbitragem seria seu custo baixo comparado com a justiça estatal, o que não se configurou nas entrevistas da pesquisa de campo. Isto se deve ao contexto de utilização da arbitragem, onde os agentes se utilizam dos órgãos arbitrais institucionais de grande porte, com custos altos, gerado pela falta de confiança em órgãos arbitrais de pequeno porte ou arbitragens ad hoc. Há a necessidade do surgimento de órgãos arbitrais com custos baixos e mesma competência e credibilidade dos grandes órgãos arbitrais institucionais. Necessita-se também da formação de árbitros competentes e críveis para julgarem questões arbitrais de baixos valores, pela arbitragem ad hoc, com a intenção de diminuir os valores de custo de uma arbitragem. A soma destas duas providências providenciará o acesso de empresas construtoras pequenas e médias à utilização da arbitragem, levando-as a terem as mesmas vantagens das empresas construtoras de maior porte.

Finalmente, propõe-se preventivamente que o processo do projeto seja encerrado de maneira adequada antes da sua orçamentação e contratação, com execução e compatibilização de todos os projetos complementares ao arquitetônico, visto que parte dos motivos de conflito decorrem de falhas em projetos e alterações deste no decorrer da obra. Além disso, a implantação de ferramentas de planejamento e gestão dentro das empresas construtoras com o objetivo de se evitar as falhas apontadas também concorrem para evitar o surgimento dos conflitos. 
Quanto à lei 9307/96 da arbitragem, a pesquisa demonstrou que é considerada muito clara, objetiva, e que cumpre seus objetivos. Foi percebido que se nota um anseio da utilização da jurisprudência nos processos, porém esta matéria é de escopo jurídico, não sendo objetivo desta pesquisa adentrar neste campo. 


\section{CAPÍTULO 6}

Neste capítulo são apresentadas as considerações finais, levando-se em conta as limitações existentes desta pesquisa, as contribuições ao tema, o êxito obtido frente aos objetivos desta pesquisa, e as possíveis alternativas de continuidade do tema.

\section{Conclusões}

Procurou-se ao longo desta pesquisa traçar o panorama da utilização da arbitragem sob a ótica da empresa construtora, e verificar se existiam vantagens e desvantagens na sua utilização, propondo ações para incrementar seu uso, caso fosse favorável para as empresas construtoras. Entende-se que o objetivo foi atendido pela caracterização do problema e as proposições apresentadas.

O levantamento e revisão bibliográfica efetuados sobre os conceitos de contrato, seus agentes, e uma análise da lei da arbitragem demonstrou que a maioria das pesquisas sobre arbitragem é volumosa na área jurídica, com viés conceitual, e praticamente inexistente na área da engenharia civil, com poucas informações disponíveis sobre seu potencial prático de aplicação em contratos de construção civil. A pesquisa de campo, desenvolvida por meio de entrevistas com questionários estruturados lastreados na pesquisa bibliográfica e limitada pelas condições de sigilo dos contratos e processos arbitrais, trouxe à tona as vantagens de seu uso e o problema dos altos custos das arbitragens, que não havia se configurado na pesquisa bibliográfica, pela segmentação do uso da arbitragem em contratos de grande valor. Demonstrou, também, que o uso da arbitragem é ascendente nos últimos anos, pois tanto empresas construtoras como escritórios de advocacia têm inserido com freqüência cada vez maior a cláusula 
compromissória na maioria de seus contratos de obras de grandes valores, porém não a utilizando em contratos de valores baixos.

Conclui-se em vários aspectos que a arbitragem é favorável e pode ser um bom instrumento de solução das disputas para empresas construtoras, pela facilidade de sua implementação pelas cláusulas arbitrais inseridas no contrato ou posteriormente pelo compromisso arbitral, pela clareza da lei, pelo prazo curto de emissão da sentença arbitral em comparação com a justiça estatal, pela simplicidade do processo arbitral, pela qualidade técnica das sentenças e outras vantagens. Não é, no entanto, solução universal para todas as disputas em contratos de construção civil, podendo ser conveniente para aquelas identificadas e descritas na análise integrada das entrevistas, tais como disputas entre construtoras e incorporadoras, ou entre construtoras e subcontratados, e não ser conveniente em outras, tais como disputas entre compradores de frações idéias e incorporadoras.

Em relação a uma das vantagens citadas pelos entrevistados, em especial pelas empresas construtoras, o sigilo, trata-se de vantagem exclusiva para as partes do processo arbitral, e não para a sociedade, pois a publicidade das razões para uma decisão da justiça faz parte do estado de direito democrático. E neste caso a publicidade é suprimida, assim como a sentença arbitral, que, caso seja desfavorável à sociedade, não será conhecida.

No caso de não cumprimento da sentença arbitral pela parte perdedora, a ganhadora deverá solicitar na justiça estatal seu cumprimento. Poder-se-ia neste caso questionar qual a vantagem da arbitragem, já que está se recorrendo à justiça comum. Pelo fato da sentença arbitral ser definitiva, não mais será possível recorrer do mérito da questão, postergando o encerramento do processo, o que é possível na justiça estatal, mas apenas solicitar o cumprimento da sentença. Como conseqüência, abrevia-se o tempo de solução da disputa, o que continua sendo vantajoso à parte ganhadora. 
No entanto, embora se conclua que a utilização da arbitragem é vantajosa, o contexto atual de sua utilização em contratos de construção civil resume-se às grandes empresas construtoras inserindo a cláusula compromissória em grandes contratos, e valendo-se dos órgãos arbitrais institucionais de grande porte para instituir a arbitragem no caso de uma disputa. Estas grandes empresas construtoras se recusam a utilizar órgãos arbitrais institucionais de pequeno porte ou arbitragens ad hoc por não confiarem na capacidade destes órgãos ou dos árbitros.

Em relação às pequenas e médias obras, e às pequenas e médias empresas construtoras, existe um grande hiato de seu uso imposto basicamente pelo desconhecimento do mecanismo, já que em relação ao custo poderiam ser utilizados órgãos arbitrais institucionais de pequeno porte ou arbitragens ad hoc. Este segmento é uma alternativa de continuidade de pesquisa do tema, assim como o aprofundamento da pesquisa nas empresas mistas e públicas.

Outra alternativa para ampliar a pesquisa seria a de entrevistar os engenheiros gestores dos contratos das obras, que poderão fornecer novos dados sobre as causas dos conflitos e disputas, por estarem diretamente ligados à execução do empreendimento, ao passo que nas entrevistas desta pesquisa o foco foi na alta direção das empresas, cuja visão é sistêmica da corporação, e não do empreendimento.

Finalmente, percebe-se que a maioria dos contratos que inserem a cláusula compromissória ocorre entre cliente e empresa construtora, e são raros os casos entre empresas construtoras e subcontratados. Tem-se também, neste caso, uma alternativa de aprofundar o tema da pesquisa, abordando-o sob esta ótica. 


\section{REFERÊNCIAS BIBLIOGRÁFICAS}

ALMEIDA, J. A. Processo arbitral. Belo Horizonte: Del Rey, 2002.190 p.

AMARAL, A. C. R. A arbitragem no Brasil e no âmbito do comércio internacional. Disponível em http://www.hottopos.com/harvard4/ton.htm. Acesso em: 15 jan. 2010.

ARDITI, D.; PATEL, B. K. Expert System for claim management in construction projects. International Journal of Project Management, v.7, p. 141-146, Aug. 1989. Disponível em < http://www.sciencedirect.com/science? _ob=PublicationURL\&_tockey=\%23TOC\%235908\%232002\%2399979999\% 23269566\%23FLA\%23\&_cdi $=5908 \& \_p u b T y p e=J \& \_a u t h=y \& \_a c c t=C 000050$ 221\&_version $=1 \&$ _urlVersion $=0 \&$ \&userid $=10 \& \mathrm{md} 5=\mathrm{e} 5101 \mathrm{c} 69 \mathrm{~d} 3623223 \mathrm{a} 35 \mathrm{~d}$ 7d0a6ce7b354>. Acesso em: 10 jan. 2010.

BORGES, E. C. V. As vantagens da prática arbitral para a solução das controvérsias das micro e pequenas empresas, 2008. Disponível em $<w w w . c b m a e . o r g . b r / s i t e s / 1000 / 1083 / 00000242 . d o c>$. Acesso em: 15 jan. 2010.

BRASIL. Lei n.o 4591, de 16 de dezembro de 1964. Dispõe sobre o condomínio em edificações e as incorporações imobiliárias. Disponível em <http://www.planalto.gov.br/ccivil_03/Leis/L4591.htm>. Acesso em: 2 de abril de 2009.

. Lei n.o 8666, de 21 de junho de 1993. Institui normas para licitações e contratos da administração pública, e dá outras providências. Disponível em: <http://www.planalto.gov.br/ccivil_03/LEIS/L8666cons.htm>. Acesso em: 27 de novembro de 2008. 
Lei n.o 8987, de 13 de fevereiro de 1995. Dispõe sobre o regime de concessão e permissão da prestação de serviços públicos previsto no art. 175 da Constituição Federal, e dá outras providências.Disponível em: http://www.planalto.gov.br/ccivil_03/Leis/L8987cons.htm>. Acesso em: 10 de julho de 2009.

Lei n.o 9307, de 23 de setembro de 1996. Dispõe sobre a arbitragem. Disponível em:<http://www.planalto.gov.br/ccivil_03/leis/L9307.ht m> Acesso em: 12 de março de 2007.

BUENO, J. C. Mitigação de riscos na elaboração de negociação de contratos EPC. 2. Conferência anual de gestão de riscos na construção, 2008, São Paulo./no prelo/.

BRAGHETTA, A. Judiciário é parceiro na evolução da arbitragem, entrevista concedida a Lilian Matsuura. Disponível em: <http://www.conjur.com.br/2009-out-11/entrevista-adriana-braghetta-advoga da-especialista-arbitragem>. Acesso em: 21 out. 2009.

CACHAPUZ, R. R. Arbitragem: alguns aspectos do processo e do procedimento na lei no 9.307/96. Leme: Editora de Direito, 2000. 262 p.

CARVALHO, I. C. M. Possibilidade de utilização da arbitragem pela administração pública. Disponível em: http://www. Manucciadv.com.br/pag e/index.php?n1=artigos\&n2=interna\&id=26. Acesso em: 3 mar. 2008.

CHUFFI, S. Solução de conflitos por arbitragem nas relações médicopaciente regidas por contrato. 2005. 112 p. Monografia (Bacharel em Direito), Faculdade de Direito, Associação Catarinense de Ensino. Joinville, 2005.

COLAIÁCOVO, J. L.; COLAIÁCOVO, C. A. Negociação, mediação e arbitragem, teoria e prática. Rio de Janeiro: Editora Forense, 1999. 394 p. 
COSTA, W. V.; JUNQUEIRA, G. J. P. Contratos, manual prático e teórico. São Paulo: Madras Editora, 2008. 288 p.

FAGUNDES, A. B. Mediação e arbitragem: alternativas rápidas e eficientes. Revista OESP Construção, ano 5 n.1, 2000. Disponível em http://www.ie.org.br/cmaie/informe_publicacoes.php?p=11. Acesso em: 20 dez. 2009.

FRANÇA. International Chamber of Commerce, international court of arbitration. Resolving Business Disputes Worldwide, 2002.

GIL, A. C. Como elaborar projetos de pesquisa. São Paulo: Ed Atlas, 1996. $159 \mathrm{p}$.

GONZÁLEZ, M. S. Os contratos de empreitada e de incorporação imobiliária: uma exposição das principais características. In: ENCONTRO NACIONAL DE TECNOLOGIA DO AMBIENTE CONSTRUÍDO, 1998, Florianópolis. Anais...Florianópolis: Universidade de Santa Catarina, 7., 1998, p. 483-490.

GRION, R. S. Boletim de arbitragem n. 2, agosto/setembro 2007, Pinheiro Neto Advogados. Disponível em <http://www.pinheironeto.com.br/upload/tb_ pinheironeto_boletim/pdf/250907160555Boletim2_AgoSet_2007.pdf>. Acesso: em 13 mai. 2008.

INTERNATIONAL FEDERATION OF CONSULTING ENGINEERSCONSEILS . Apresenta atividades desenvolvidas. Disponível em: <ttp://www .fidic.org/>. Acesso em: 24 mar 2009.

IYER, K. C.; SATYANARAYANA K. Final and binding power clause in indian construction. International Journal of Project Management, v.20, p.13-22, Jan. 2002. Disponível em: <http://www.sciencedirect.com/science?_ob=Publi 
cationURL\&_tockey=\%23TOC\%235578\%231995\%23999799998\%2315502 7\%23FLP\%23\&_cdi =5578\&_pubType =J\&_auth=y\&_acct=C000050221\&_ver sion $=1 \&$ _urlVersion $=0 \&$ \&userid $=10 \& \mathrm{md} 5=05 \mathrm{f} 206 \mathrm{dcd} 6 \mathrm{aff} 39 \mathrm{ce} 09 \mathrm{a} 558 \mathrm{~b} 50 \mathrm{bb}$ c304>. Acesso em: 10 jan. 2010.

JANNADIA, O.; ASSAF, S.; B. A. A.; NAJI, A. Contractual methods for dispute avoidance and resolution (DAR). International Journal of Project Management, v. n. 18, p. 41-49. Feb. 2000. Disponível em: $<$ http://www.sciencedirect.com/science?_ob=ArticleURL\&_udi=B6V9V-49V0

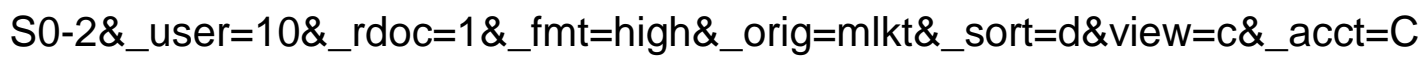
000050221 \&_version $=1 \&$ _urlVersion $=0 \&$ userid $=10 \& \mathrm{md} 5=2037 \mathrm{a} 69801 \mathrm{ea} 96$ 25544fba5a94649296>. Acesso em: 10 jan. 2010.

JESUS, E. A. Arbitragem, questionamentos e perspectivas. São Paulo: Editora Juarez de Oliveira, 2003. 176 p.

MAIA NETO, F. Arbitragem, a justiça alternativa. Belo Horizonte: Editora Precisão, 2002. $108 \mathrm{p}$.

MARCATO, M. A. A arbitragem nos contratos de obras e serviços. Revista Engenharia n. 582, p.104-107, jul/ago 2007.

MARTINS, P. B.; LEMES, S. M. F.; CARMONA, C. A. Aspectos fundamentais da lei da arbitragem. Rio de Janeiro: Editora Forense, 1999. $522 \mathrm{p}$.

MCT Ministério da Ciência e Tecnologia. Necessidades de ações de desenvolvimento tecnológico na produção da construção civil e da construção habitacional. São Paulo: fórum da competitividade, 2000. 21 p.

MELHADO, S. B. Gestão, cooperação e integração para um novo modelo voltado à qualidade do processo do projeto na construção de 
edifícios. 2001. 235 p. Tese (Livre-docência). Escola Politécnica, Universidade de São Paulo. São Paulo, 2001.

MESQUITA, M. J. M. Subsídios para o planejamento da qualidade em edifícios do segmento hoteleiro. 2006. 454 p. Tese (Doutorado). Escola Politécnica, Universidade de São Paulo, São Paulo, 2006.

OLIVEIRA, G. H. J. A arbitragem e as parcerias público-privadas. Revista Eletrônica de Direito Administrativo Econômico, Salvador, Instituto de Direito Público da Bahia, número 2, mai-jun-jul, 2005. Disponível em: http://www.direitodoestado.com/revista/REDAE-2-MAIO-2005-GUSTAVO\%2 OJUSTINO.pdf. Acesso em: 18 mai. 2009.

PEDROSA, V. A. Reivindicações em contratos de empreitada no Brasil. 1994. 95 p. Dissertação (Mestrado). Escola Politécnica, Universidade de São Paulo, São Paulo, 1994.

PROJECT MANAGEMENT INSTITUTE. PMBOK: um guia do conjunto de conhecimento de gerenciamento de projetos. Newton Square, Pennsylvania EUA: Project Management Institute, 2000. 159 p.

PMBOK: um guia do conjunto de conhecimento de gerenciamento de projetos. Newton Square, Pennsylvania EUA: Project Management Institute, 2004. 218 p.

RICARDINO, R. Administração de contratos em construção pesada no Brasil: um estudo da interface com o processo da análise de risco. 2007. 104 p. Dissertação (Mestrado). Escola Politécnica, Universidade de São Paulo, São Paulo, 2007.

SANCHEZ, P. L. P. Metodologia da Prova Pericial. São Paulo. Disciplina PSI-5001 de Pós-Graduação da Engenharia Elétrica, Escola Politécnica, Universidade de São Paulo, 2007. 
SCHABBEL, C. Otimização da Habilidade Negocial no Contexto Organizacional e Comercial. São Paulo: IBAPE, 2002/No prelo/.

SIMÃO, J. F. Direito civil: contratos. São Paulo: Atlas, 2008. 333 p. (Série leituras jurídicas: provas e concursos; v.5).

STRENGER, I. Arbitragem Comercial Internacional. São Paulo: Editora LTr, 1996. 655 p. 


\section{BIBLIOGRAFIA CONSULTADA}

ABIKO, A. K. et al Setor de construção civil:segmento de edificações. Brasília: SENAI, 2005. 159 p.

BARBI FILHO, C. Execução específica de cláusula arbitral. Revista de Direito Administrativo, n. 97 p. 29.

CAMPOS, V. F. Gerenciamento da rotina do trabalho do dia-a-dia. Belo Horizonte: Editora Líttera Maciel, 1994. 276 p.

LEE, B A. Legal pitfalls of downsizing. Human Resource Management Review. v.5, p. 1-23. 1995. Disponível em: <http://www.sciencedirect.com/s cience?_ob=ArticleListURL\&_method=list\&_ArticleList $\mid \mathrm{D}=1197185293$ \&_sor $\mathrm{t}=\mathrm{r} \&$ view $=\mathrm{c} \&$ acct $=\mathrm{C} 000050221$ \&_version $=1$ \&_urlVersion=0\&_userid $=10 \& \mathrm{~m}$ d5=99fc9acd2f4d52dbbd16c3e666f45c5d>. Acesso em: 10 jan 2010.

MIARA, C. K. Arbitragem Privada Internacional: A arbitragem como sistema de solução de conflitos privados internacionais. Ponta Grossa in: SIMPÓSIO INTERNACIONAL PROCESSO CIVILIZADOR, 9., 2005. Ponta Grossa./No prelo/

PUCCI, A. N. Arbitragem comercial nos países do Mercosul. São Paulo: Editora LTr Editora, 1997. 335 p.

SCHANER, L. S. Minutas de Cláusulas de Arbitragem Para Contratos de Construção. Trabalho apresentado no $2^{-}$Congresso Internacional da Arbitragem na Engenharia. São Paulo, 2008./No prelo/.

VAZ, G. J. Breves Considerações Sobre os Dispute Boards no Direito Brasileiro. Revista de Arbitragem e Mediação n. 10, p.165-171, jul/set 2006. 
YIN, ROBERT K, Estudo de caso: planejamento e métodos. 3.ed Porto Alegre: Bookman, 2005.212 p. 


\section{APENDICE 1}

\subsection{Transcrição da entrevista com órgão arbitral institucional 01}

1. Dos processos arbitrais deste órgão, as empresas construtoras correspondem a qual proporção sobre os casos totais?

R: Correspondem a aproximadamente a $40 \%$ do total. A maior parte das arbitragens corresponde a questões societárias.

2. Dos processos arbitrais que envolvem empresas construtoras, qual a proporção de utilização de cláusula compromissória, e qual a proporção de uso de compromisso arbitral?

R: O uso do compromisso arbitral é muito raro, creio que de todos os caso que envolvem construtores estes correspondem a $1 \%$.

3. Dos contratos com cláusulas compromissórias, proporcionalmente, quantos se referem a contratos privados? E a PPP?

R: Não houve nenhum caso de utilização para contratos de PPP, parece haver medo de sua utilização.

4. Dos contratos com compromisso arbitral, proporcionalmente, quantos se referem contratos privado? E a PPP?

R: Todos se referem a contratos privados.

5. Há algum setor onde o emprego do mecanismo é mais significativo (Infraestrutura, Edificações)?

R: Infraestrutura utiliza mais, em geral com PCH's (Pequenas Centrais Hidrelétricas)

6. Qual o volume de casos em que as partes envolvidas na arbitragem são empresas construtoras e agentes contratados (por exemplo, subempreiteiros, fornecedores, etc.)? 
R: Isto praticamente não ocorre, é mais comum a construtora arrolar o subcontratado no caso.

7. Existem casos de arbitragem entre construtoras/incorporadoras e adquirentes de frações ideais? Qual o volume sobre o total de casos de empresas construtoras?

$R$ : Não, pois o custo não compensa.

8. Quais as razões pelas quais as empresas construtoras utilizam a arbitragem?

$R:$ São três fatores:

- Sigilo

- Rapidez

- Qualidade da decisão, baseada nos fatos e mais especializada

9. O que explica sua não utilização?

R: As grandes empresas só vêem vantagens. Para construtoras de pequeno porte e ações idem, parece que não há interesse em haver resolução, interessa postergar, para pagar menos do que é devido.

10. E quais as desvantagens que as empresas apontam?

R: Não vejo, mas construtoras gostariam que o processo fosse mais rápido,

11. Como tais empresas avaliam os resultados obtidos?

R: Em geral as partes estão satisfeitas, até a perdedora pelo menos resolveu o assunto.

12. Quais os agentes que empregam com maior freqüência as arbitragens (incorporador, empresa construtora, subcontratado, agente financeiro, etc.)? 
R: Contratante e construtora.

13. Contratos administrativos com arbitragem - já houve tentativa de utilização?

R: Não.

14. E empresas públicas ou mistas já tentaram se valer da arbitragem?

R: Nenhuma tentou.

15. O prazo constante da lei $9307 / 96$, de 180 dias, é cumprido ou as partes elegem novos prazos?

R: As partes sempre elegem novos prazos. O prazo é curto, corre-se o risco de descumprir os princípios do contraditório e da ampla defesa.

16. Quais melhorias este órgão sugere para o processo arbitral, em relação à lei 9307/96?

R: A lei é ótima, não há necessidade de nenhuma mudança.

17. Quais ações este órgão sugere para incrementar o uso da arbitragem?

R: Há a necessidade de Câmaras arbitrais com a mesma competência das grandes, com valores mais baixos. A arbitragem ainda é cara. Outra necessidade é o maior conhecimento do mecanismo por parte dos agentes.

18. Houve um incremento na quantidade de uso de arbitragem neste órgão?

R: Houve sem dúvida um crescimento da arbitragem nos últimos cinco anos, sobretudo nos últimos dois anos em que o crescimento foi quase exponencial. Na construção civil, este crescimento acompanhou o crescimento geral do Instituto da Arbitragem. 


\subsection{Transcrição da entrevista com órgão arbitral institucional 02}

1. Dos processos arbitrais deste órgão, as empresas construtoras correspondem a qual proporção sobre os casos totais?

R: Por volta de $10 \%$ do total.

2. Dos processos arbitrais que envolvem empresas construtoras, qual a proporção de utilização de cláusula compromissória, e qual a proporção de uso de compromisso arbitral?

R: Sempre cláusula compromissória, acredito que só se usará compromisso arbitral se a cláusula compromissória for deficitária, com erros.

3. Dos contratos com cláusulas compromissórias, proporcionalmente, quantos se referem a contratos privados? E a PPP?

R: $100 \%$ contratos privados.

4. Dos contratos com compromisso arbitral, proporcionalmente, quantos se referem contratos privado? E a PPP?

R: Não há.

5. Há algum setor onde o emprego do mecanismo é mais significativo (Infraestrutura, Edificações)?

R: Edificações.

6. Qual o volume de casos em que as partes envolvidas na arbitragem são empresas construtoras e agentes contratados (por exemplo, subempreiteiros, fornecedores, etc.)?

R: Direi que metade correspondem a construtora e cliente e construtora e consorciado, e a outra metade a construtora e subempreiteiro. 
7. Existem casos de arbitragem entre construtoras/incorporadoras e adquirentes de frações ideais? Qual o volume sobre o total de casos de empresas construtoras?

R: Somente um caso, por prazo de entrega não cumprido. Porém o código do consumidor é mais favorável à parte hipossuficiente (a parte mais fraca).

8. Quais as razões pelas quais as empresas construtoras utilizam a arbitragem?

R: Querem resolver a questão com rapidez, eficácia e especialidade.

9. O que explica sua não utilização?

R: O desconhecimento da utilização da arbitragem; o custo elevado, o custo-benefício às vezes não é vantajoso; valores baixos de contenda não devem ser tratados pela arbitragem, sugiro a medição e depois a arbitragem, com uma cláusula escalonada. $A$ arbitragem tem um nicho específico de valor.

10. E quais as desvantagens que as empresas apontam?

R: Nunca alguma me apontou desvantagens.

11. Como tais empresas avaliam os resultados obtidos?

R: Quem perdeu sempre cumpriu voluntariamente, avaliam favoravelmente, as partes chegam até a fazer negócios novamente.

12. Quais os agentes que empregam com maior freqüência as arbitragens (incorporador, empresa construtora, subcontratado, agente financeiro, etc.)?

R: Todos em geral.

13. Contratos administrativos com arbitragem - já houve tentativa de utilização? 
R: Nunca vi.

14. E empresas públicas ou mistas já tentaram se valer da arbitragem?

R: Não.

15. O prazo constante da lei $9307 / 96$, de 180 dias, é cumprido ou as partes elegem novos prazos?

R: O prazo acaba sendo flexível, os 180 dias não são cumpridos, 0 prazo médio é de 1 ano.

16. Quais melhorias este órgão sugere para o processo arbitral, em relação à lei 9307/96?

R: A lei é boa, mas acho que falta um glossários definindo e explicando os termos utilizados.

17. Quais ações este órgão sugere para incrementar o uso da arbitragem?

R: Divulgação, palestras, cursos.

18. Houve um incremento na quantidade de uso de arbitragem neste órgão?

R: Sim, a tendência é aumentar.

\subsection{Transcrição da entrevista com órgão arbitral institucional 03}

1. Dos processos arbitrais deste órgão, as empresas construtoras correspondem a qual proporção sobre os casos totais?

R: Aproximadamente $30 \%$ dos casos referem-se a arbitragens para empresas construtoras. Com exceção destas, a maior porção parte das arbitragens envolve disputas e dissoluções societárias de empresas. Há uma grande procura também pelos Dispute Review Board. 
2. Dos processos arbitrais que envolvem empresas construtoras, qual a proporção de utilização de cláusula compromissória, e qual a proporção de uso de compromisso arbitral?

R: Todos os casos referem-se a cláusula compromissória, não há nenhum caso com compromisso arbitral.

3. Dos contratos com cláusulas compromissórias, proporcionalmente, quantos se referem a contratos privados? E a PPP?

R: Todos os casos referem-se a contratos privados, não tivemos nenhum caso de PPP.

4. Dos contratos com compromisso arbitral, proporcionalmente, quantos se referem contratos privado? E a PPP?

R: Não há nenhum caso com compromisso arbitral.

5. Há algum setor onde o emprego do mecanismo é mais significativo (Infraestrutura, Edificações)?

R: Equilibrado, não se pode afirmar que algum setor tenha mais casos que $o$ outro.

6. Qual o volume de casos em que as partes envolvidas na arbitragem são empresas construtoras e agentes contratados (por exemplo, subempreiteiros, fornecedores, etc.)?

R: Existe esta situação, e pode-se dizer que dos casos que envolvem construtoras, aproximadamente $10 \%$ referem-se a ações entre construtoras e subcontratados.

7. Existem casos de arbitragem entre construtoras/incorporadoras $s e$ adquirentes de frações ideais? Qual o volume sobre o total de casos de empresas construtoras?

R: Não, pois o Código de Defesa do Consumidor desestimula a arbitragem, dando melhores condições ao adquirente de se defender. 
8. Quais as razões pelas quais as empresas construtoras utilizam a arbitragem?

R: Posso citar: rapidez e agilidade, que permitem a continuidade das obras e sigilo, que às vezes garante até a sobrevivência das empresas, por evitar boatos no mercado.

9. O que explica sua não utilização?

R: Em geral o desconhecimento do mecanismo pelas empresas, a insegurança causada por este desconhecimento, o objetivo de ganhar tempo e os advogados que preferem não utilizá-la por preconceito, desconhecimento ou estratégia de defesa.

10. E as desvantagens?

R: O preço.

11. Como tais empresas avaliam os resultados obtidos?

R: Em geral, quem ganha gosta, em função do prazo. Há um sentimento também de finalização do conflito, pelo menos resolveu-se o problema. E a maioria gosta do processo, por ser muito claro, transparente e participativo.

12. Quais os agentes que empregam com maior freqüência as arbitragens (incorporador, empresa construtora, subcontratado, agente financeiro, etc.)?

R: No setor de Infraestrutura são as construtoras e subcontratados; no setor de edificações são as financeiras e incorporadoras.

13. Contratos administrativos com arbitragem - já houve tentativa de utilização?

$R:$ Não.

14. E empresas públicas ou mistas já tentaram se valer da arbitragem? 
R: Não.

15. O prazo constante da lei $9307 / 96$, de 180 dias, é cumprido ou as partes elegem novos prazos?

R: Geralmente cumprem.

16. Quais melhorias este órgão sugere para o processo arbitral, em relação à lei 9307/96?

R: A lei é transparente e perfeita.

17. Quais ações este órgão sugere para incrementar o uso da arbitragem?

R: Divulgação, divulgação e divulgação. Isto junto a construtoras e advogados, e a todos em geral.

18. Houve um incremento na quantidade de uso de arbitragem neste órgão?

R: Sim, houve um crescimento de $100 \%$ aprox. no uso da arbitragem, especialmente de 2007 a 2009. Acredito que houve proporcionalidade deste crescimento nos contratos de construção civil. 


\section{APENDICE 2}

\subsection{Transcrição da entrevista com empresa construtora $\mathbf{C 1}$}

1. Quais as razões pelas quais a empresa construtora inclui em seus contratos a cláusula compromissória?

R: Tempo, economizar tempo é o principal vetor para a escolha, Outro aspecto importante é a expertise do árbitro, que se espera que o juiz não tenha, porém com ressalvas. Foro arbitral não é melhor nem pior que o juízo estatal, é uma boa ferramenta. O tempo é importante. Somente utilizamos para contratos acima de $R \$ 20.000 .000,00$. Segurança também é um ítem importante.

2. Quais as razões que explicam a não inclusão da cláusula compromissória em seus contratos?

R: Não acreditamos na idoneidade de câmara e juízes arbitrais quaisquer. Há que ter confiança, e uma câmara arbitral com idoneidade custa caro, por isso só escolhemos arbitragem para valores acima de $R \$$ 20.000.000,00. Em casos em que, de maneira estratégica é importante postergar a solução, não se usa a arbitragem.

3. Qual o volume de sua inclusão para cada tipo de obra em contratos privados e de PPP?

R: Em PPP existe insegurança jurídica na sua utilização, por causa do interesse público. Não temos nenhuma, porém lembro que os contratos com financiamento internacional exigem a cláusula de arbitragem. Em contratos de valor baixo não se utiliza arbitragem. Depende do valor e complexidade da relação. 
4. Quais as razões pelas quais, quando não utilizam a cláusula compromissória, fazem uso do compromisso arbitral em situações de disputa?

R: Não utilizamos.

5. Em que proporção isso ocorre e para que tipos de obras?

$R$ : Não ocorreu

6. Utiliza a cláusula compromissória também com os agentes contratados? Com quais e em que percentuais?

R: Depende da complexidade e valor, não há uma regra, depende o binômio já citado, complexidade e valor. Pode ser subempreiteiro com questões ambientais, etc.

7. Quais segmentos de obras mais a utilizam?

R: Infraestrutura. Mas continua o binômio complexidade e valor.

8. É incorporador? Caso seja, costuma utilizar a cláusula compromissória em contratos de venda de frações ideais?

$R$ : Não somos incorporadores.

9. Qual o tipo de contrato utilizado, Empreitada Global, EPC, Aliança, FIDIC?

R: Todos, aliança mais para área industrial, em contratos maiores $o$ modelo EPC, sempre com arbitragem.

10. Em contratos administrativos com empresas publicas ou mistas a empresa construtora já assinou contrato com cláusula compromissória?

R: Não, salvo se for exigência do financiador, mas que causa insegurança no poder público.

11. Que vantagens percebe na utilização da arbitragem? 
R: Rapidez, eficiência.

12. E quais são as desvantagens?

R: Insegurança causada pelos árbitros, acreditamos na figura do juiz estatal como imparcial. Na arbitragem o advogado tem insegurança em relação ao resultado da demanda por não haver jurisprudência.

13. Como avaliam os resultados obtidos?

R: O parâmetro é a eficiência, decisões bem fundamentadas.

14. Quais melhorias sugerem para o processo?

R: A lei é boa, faltam referencias. Respeitado o sigilo, deve existir um banco de sentenças, com fins de haver jurisprudência.

15. Quais os motivos dos conflitos?

R: Responsabilidade dos agentes: quem errou? Projetos com erros, omissões, problemas geológicos.

16. Utiliza arbitragem Institucional ou ad hoc?

R: Somente institucional.

17. Quantos árbitros são escolhidos?

R: Um árbitro, salvo se a complexidade exigir ou não houver um consenso serão três. É importante dois técnicos e um advogado.

18. O prazo é seguido?

R: Não, os processos duram até 2 anos.

19. Já utilizou Dispute Review Boards ou Dispute Adjudication Board?

R: Não. 


\subsection{Transcrição da entrevista com empresa construtora C2}

1. Quais as razões pelas quais a empresa construtora inclui em seus contratos a cláusula compromissória?

R: Pela segurança de assuntos técnicos serem resolvidos por especialistas, pela rapidez, pelo fator psicológico de chegar a um resultado. A CCBC demora em média 14 meses para chegar a um veredicto.

2. Quais as razões que explicam a não inclusão da cláusula compromissória em seus contratos?

$R:$ É um procedimento caro, por isso serve a poucos casos.

3. Qual o volume de sua inclusão para cada tipo de obra em contratos privados e de PPP?

R: Não houve nenhum caso em PPP. Quanto às obras privadas, diria que em $20 \%$ dos casos é utilizada a cláusula compromissória, que porém corresponde a $60 \%$ do valor da nossa carteira de obras. Em obras de valores altos prefere-se a arbitragem, assim como em obras complexas. Em obras de valor baixo não se utiliza arbitragem.

4. Quais as razões pelas quais, quando não utilizam a cláusula compromissória, fazem uso do compromisso arbitral em situações de disputa?

R: Nunca usamos.

5. Em que proporção isso ocorre e para que tipos de obras?

R: Não ocorreu

6. Utiliza a cláusula compromissória também com os agentes contratados? Com quais e em que percentuais? 
R: Não utilizamos, por causa do valor da arbitragem, mas estamos estudando seu uso.

7. Quais segmentos de obras mais a utilizam?

R: Infraestrutura.

8. É incorporador? Caso seja, costuma utilizar a cláusula compromissória em contratos de venda de frações ideais?

R: Não incorporamos.

9. Qual o tipo de contrato utilizado, Empreitada Global, EPC, Aliança, FIDIC?

R: Depende do cliente, a maioria das obras privadas prefere o EPC, e estamos tentando utilizar Aliança.

10. Em contratos administrativos com empresas publicas ou mistas a empresa construtora já assinou contrato com cláusula compromissória?

R: Sim, quando há financiamento externo.

11. Que vantagens percebe na utilização da arbitragem?

R: Velocidade e segurança.

12. E quais são as desvantagens?

R: Custo!

13. Como avaliam os resultados obtidos?

R: Satisfatórios, pelo fato da decisão ser técnica.

14. Quais melhorias sugerem para o processo?

R: A lei é boa, porém executar a sentença no judiciário é problemático.

15. Quais os motivos dos conflitos? 
R: Falhas e modificações em projetos, falta de cumprimento das obrigações pelo contratante, problemas climáticos que geram atrasos..

16. Utiliza arbitragem Institucional ou ad hoc?

R: Somente institucional, pela credibilidade.

17. Quantos árbitros são escolhidos?

R: Sempre três, em geral advogados, ou presidente da corte advogado. As empresas são contenciosas, por isso advogados.

18. O prazo é seguido?

R: Não, dificilmente, o prazo da CCBC é em média de 14 meses.

19. Já utilizou Dispute Review Boards ou Dispute Adjudication Board?

R: Não.

\subsection{Transcrição da entrevista com empresa construtora C3}

1. Quais as razões pelas quais a empresa construtora inclui em seus contratos a cláusula compromissória?

R: A maioria de nossas obras são públicas, e nosso contratos de obras contam com financiamento externo, e normalmente nesses casos é uma exigência natural. Em obras privadas, utilizamos a arbitragem por designar para julgamento quem conhece a causa, e também a celeridade.

2. Quais as razões que explicam a não inclusão da cláusula compromissória em seus contratos? 
R: Não utilizamos arbitragem em contratos onde não há um entendimento sedimentado sobre seu uso, tais como contratos administrativos de obras públicas. Em regar, usamos a arbitragem para contratos de valores maiores, e não em contratos de valores pequenos.

3. Qual o volume proporcional de sua inclusão em contratos privados e de PPP?

R: Privados, a grande maioria; PPP, não temos nenhum contrato ativo em São Paulo, quando havia utilizamos a cláusula compromissória.

4. Quais as razões pelas quais, quando não utilizam a cláusula compromissória, fazem uso do compromisso arbitral em situações de disputa?

R: Não tivemos nenhum caso.

5. Em que proporção isso ocorre e para que tipos de obras?

R: Não tivemos nenhum caso.

6. Utiliza a cláusula compromissória também com os agentes contratados? Com quais e em que proporcionalidade?

R: Pouco, a maioria dos contratos com subcontratados são feitos diretamente nas obras. Caso o contrato seja de valor maior, ele passa pelo jurídico e utilizamos a arbitragem.

7. Quais segmentos de obras mais a utilizam, infraestrutura ou edificações?

R: Mais em edificações, pois são clientes privados.

8. É incorporador? Caso seja, costuma utilizar a cláusula compromissória em contratos de venda de frações ideais?

R: Não usamos. 
9. Qual o tipo de contrato utilizado, Empreitada Global, EPC, Aliança, FIDIC, contrato próprio?

R: Contratos de empreitadas a preços unitários.

10. Em contratos administrativos com empresas publicas ou mistas a empresa construtora já utilizou a cláusula compromissória?

R: Sim, só nos casos em que o edital de concorrência prevê seu uso, com empresas de economia mista. Em obras públicas, não.

11. Que vantagens percebe na utilização da arbitragem?

R: Árbitros com entendimento no assunto e celeridade.

12. E quais são as desvantagens?

R: Em algumas questões o judiciário é mais confortável, é mais barato para valores de contrato baixos. O prazo, às vezes é bom o processo demorar; temos poucos árbitros de renome, e parte deles estão impedidos de julgar, por terem feito parte de outros processos que envolvem as empresas.

13. Como avaliam os resultados obtidos?

R: Bons, dentro das expectativas, e pela rapidez.

14. Quais melhorias sugerem para o processo?

R: A lei é boa, simples, curta, rápida. Falta utilizar jurisprudência, o que a lei não permite pelo sigilo, e nesse caso ficamos na mão do árbitro.

15. Quais os motivos dos conflitos?

R: Inadimplementos em geral, que é o descumprimento do contrato, tais como falta de licenciamento ambiental, falta de correção monetária, não pagamento, prazo, falta de verba, política fiscal. Existem também problemas geológicos. 
16. Utiliza arbitragem Institucional ou ad hoc?

R: Somente institucional.

17. Quantos árbitros são escolhidos? Qual a composição do tribunal (advogados, engenheiros, outros)?

R: Sempre três, todos advogados. Se necessário, fazemos perícia com engenheiro.

18. O prazo é seguido?

R: Sim.

19. Já utilizou Dispute Review Boards ou Dispute Adjudication Board?

R: Sim, DRB, que terminou em arbitragem . 


\section{APENDICE 3}

\subsection{Transcrição da entrevista com escritórios de advocacia E1.}

1. Dos casos levados a tribunais arbitrais qual o volume destes se refere a empresas construtoras?

R: Aproximadamente $1 / 3$ dos casos.

2. Quantas arbitragens referiam-se a obras privadas?

R: Todas.

3. Quantas arbitragens referiam-se a obras de PPP?

R: Nenhuma.

4. Que vantagens percebe na utilização da arbitragem?

$R$ : Custo, sigilo e rapidez da sentença.

5. E quais as desvantagens?

R: A submissão a uma única decisão, sem possibilidade de recorrer ou postergar a sentença.

6. Qual a freqüência de inclusão de cláusula compromissória nos contratos que realiza para seus clientes construtoras?

R: Quase $100 \%$.

7. Há algum agente que emprega com maior freqüência a arbitragem?

$R$ : As construtoras.

8. Há algum setor onde o emprego do mecanismo é mais significativo (Infraestrutura, Edificações)? 


\section{R: Edificações.}

9. Incorporações a utilizam para solucionar disputas com adquirentes das frações ideais?

R: Não, utilizam somente quando da aquisição de áreas para empreendimentos imobiliários.

10. Qual o tipo de contrato utilizado, empreitada global, EPC, aliança, FIDIC?

$R$ : Contratos próprios, redigidos pelo meu escritório.

11. Já se utilizou de arbitragem em contratos administrativos?
R: Nunca.

12. Como as empresas avaliam os resultados obtidos?

R: Cumprem as sentenças.

13. Quais melhorias sugerem para o processo?

R: A lei foi bem elaborada, não vejo necessidade de melhorias.

14. Quais os motivos dos conflitos?

R: Falta de gestão e planejamento, fato de Deus (chuvas), alterações no contexto econômico durante a obra.

15. Utiliza arbitragem institucional ou ad hoc?

R: Sempre institucional.

16. Quantos árbitros são escolhidos?

R: Sempre três, com profissões diferentes, tais como advogado, economista e engenheiro.

17. O prazo estipulado na lei (180 dias) é seguido? 
R: Em geral é prorrogado, e a sentença em média é proferida 60 dias após a fase de instrução das provas.

\subsection{Transcrição da entrevista com escritório de advocacia E2.}

1. Dos casos levados a tribunais arbitrais qual o volume destes se refere a empresas construtoras?

R: Metade dos casos é de empresas construtoras.

2. Quantas arbitragens referiam-se a obras privadas?

R: Todas elas.

3. Quantas arbitragens referiam-se a obras de PPP?

R: Nenhum dos casos.

4. Que vantagens percebe na utilização da arbitragem?

R: Rapidez, pois não há recursos de apelação; julgamento técnico; participação ativa do julgador na prova.

5. E quais as desvantagens?

R: Decisões contrárias ao direito, não passíveis de revisão: às vezes o árbitro tenta ser um mediador, esquecendo-se que é um juiz; custo alto; emissão de decisões não técnicas; a arbitragem não se presta a resolver negócios de baixo valor, por exemplo, menos de $R \$$ 2.000.000,00.

6. Qual a freqüência de inclusão de cláusula compromissória nos contratos que realiza para seus clientes construtoras?

$R$ : Em todos os meus clientes construtoras. 
7. Há algum agente que emprega com maior freqüência a arbitragem?

R: O contratante em $100 \%$ dos casos, no caso a construtora.

8. Há algum setor onde o emprego do mecanismo é mais significativo (Infraestrutura, Edificações)?

R: Obras com valores de contratação altos; obras de infraestrutura e grandes incorporações.

9. Incorporações a utilizam para solucionar disputas com adquirentes das frações ideais?

R: Sim, e muito. Como o custo é alto, facilita o entendimento.

10. Qual o tipo de contrato utilizado, empreitada global, EPC, aliança, FIDIC?

R: Contrato de empreitada global e os contratos FIDIC, estes em poucos casos.

11. Já se utilizou de arbitragem em contratos administrativos?

R: Não.

12. Como as empresas avaliam os resultados obtidos?

R: Embora nem sempre o resultado seja favorável à construtora, estas preferem manter a cláusula arbitral levando em conta o enfoque positivo da rapidez da definição do resultado, os juízes arbitrais muitas vezes julgam por equidade e preferem fazer um "acordão" em vez dar continuidade ao processo.

13. Quais melhorias sugerem para o processo?

R: A lei é clara e aberta, poderia ser interessante submeter a arbitragem a alguma forma de controle pelo STJ e STF, a fim de se evitar sentenças que contrariem a jurisprudência.

14. Quais os motivos dos conflitos? 
R: Os conflitos se dão nas vistorias intermediárias e recebimento da obra, por vícios construtivos.

15. Utiliza arbitragem Institucional ou ad hoc?

R: Institucional.

16. Quantos árbitros são escolhidos?

R: Três ou cinco, um advogado, mais dois engenheiros ou um advogado e um engenheiro e um contador. Para valores pequenos utilizo apenas um árbitro.

17. O prazo estipulado na lei (180 dias) é seguido?

R: Sempre é prorrogada, em médio gasta-se um ano.

\subsection{Transcrição da entrevista com escritório de advocacia E3.}

1. Dos casos levados a tribunais arbitrais, qual o volume destes se refere a empresas construtoras?

$R$ : De aproximadamente 80 processos, pelo menos $20 \%$ referem-se a empresas construtoras ou agentes ligados a um contrato de construção civil.

2. Quantas arbitragens referiam-se a obras privadas?

R: Todas.

3. Quantas arbitragens referiam-se a obras de PPP?

R: Nenhuma.

4. Que vantagens percebe na utilização da arbitragem?

R: Celeridade, sigilo, custo-benefício, qualidade da decisão 
5. E quais as desvantagens?

R: Custo financeiro.

6. Qual a freqüência de inclusão de cláusula compromissória nos contratos que realiza para seus clientes construtoras?

R: Já utilizei, mas a freqüência de inclusão de cláusula é baixa.

7. Há algum agente que emprega com maior freqüência a arbitragem?

R: Nos contratos entre incorporadoras e construtoras o uso é mais freqüente; em acordos de acionistas, o uso é quase $100 \%$.

8. Há algum setor onde o emprego do mecanismo é mais significativo (Infraestrutura, Edificações)?

R: Obras de infraestrutura, notadamente em PCH's, Pequenas Centrais Hidrelétricas.

9. Incorporações a utilizam para solucionar disputas com adquirentes das frações ideais?

R: Não, pois a lei de Incorporações é mais eficaz para o caso de rescisões, e o custo seria muito alto.

10. Qual o tipo de contrato utilizado, empreitada global, EPC, aliança, FIDIC?

R: Em geral contrato de empreitada global e os contratos EPC, porém já vi todos os tipos citados, em geral o contrato já chega pronto ou faço contrato próprio. Cada cliente tem suas peculiaridades.

11. Já se utilizou de arbitragem em contratos administrativos?

R: Um caso, de empresa mista. As empresas mistas e estatais procuram através de seus administradores a excelência em administração, e não se oporiam em utilizar a arbitragem.

12. Como as empresas avaliam os resultados obtidos? 
R: Bom. Quem ganha gosta, quem perde não gosta, embora eu como advogado em ações que perdi tenha considerado o trabalho muito bom.

13. Quais melhorias sugerem para o processo?

R: Melhorar a cultura do ambiente mais propício à utilização da arbitragem. Juízes já incentivam seu uso, com o passar do tempo a utilização da arbitragem irá aumentar.

14. Quais os motivos dos conflitos?

R: Problemas em projetos, deficiências em planejamento e gestão das obras, falta de dinheiro, projetos que são modificados com a obra em andamento e chuva. Serviços extras sempre.

15. Utiliza arbitragem Institucional ou ad hoc?

R: Institucional, embora já tenha feito uma arbitragem ad hoc.

16. Quantos árbitros são escolhidos?

R: Sempre três, com a composição de presidente da mesa um advogado, mais um engenheiro e um contador.

17. O prazo estipulado na lei (180 dias) é seguido?

R: Nunca, a média é de 14 meses. 